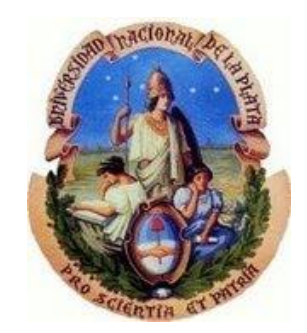

UNIVERSIDAD NACIONAL DE LA PLATA

FACULTAD DE CIENCIAS VETERINARIAS

Trabajo de Tesis realizado como requisito para optar al título de

DOCTOR EN CIENCIAS VETERINARIAS

\title{
ESTUDIO DE LA RESPUESTA INMUNE HUMORAL EN LA GESTACIÓN PORCINA
}

AUTORA: M.V. GARRO, Adriana del Carmen DIRECTORA: Dra. KONCURAT, Mirta Adriana LUGAR DE TRABAJO: Facultad de Ciencias Veterinarias. Universidad Nacional de La Pampa

MIEMBROS DEL JURADO

Dr. MORTOLA, Eduardo (UNLP)

Dr. PORTIANSKY, Enrique Leo (UNLP)

Dr. de la SOTA, Rodolfo Luzbel (UNLP)

Año 2015 
A mi familia 


\section{AGRADECIMIENTOS}

A mi directora, Dra Mirta Adriana Koncurat, por su apoyo incondicional, su comprensión y sus conocimientos.

Al Dr Julio Idiart por sus aportes, su colaboración y sus palabras de aliento.

A los miembros del jurado de esta tesis, Dr Luzbel de la Sota, Dr Enrique Portiansky y Dr Eduardo Mortola por sus sugerencias que permitieron el mejoramiento del presente trabajo.

A mi madre que en todo momento me dio fuerzas y energías para seguir, a mi marido por su apoyo sin límites, a mis hijos que supieron comprenderme y acompañarme.

A mi compañeros de trabajo por sus palabras de aliento y de apoyo.

A la Facultad de Ciencias Veterinarias de UNLPam por brindarme la posibilidad de lograr mis objetivos. 


\section{INDICE}

Página

PRESENTACIONES EN CONGRESOS …………............................................................ VII

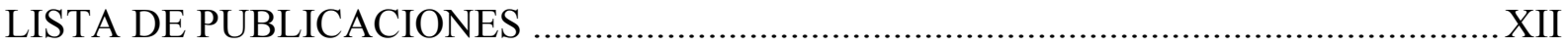

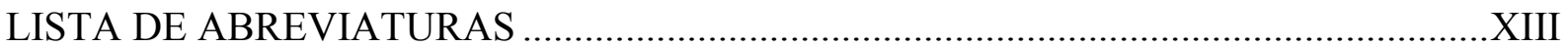

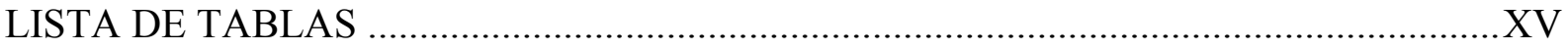

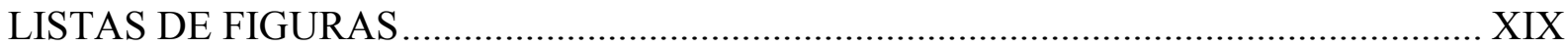

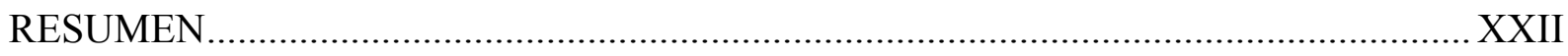

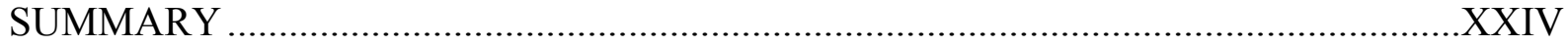

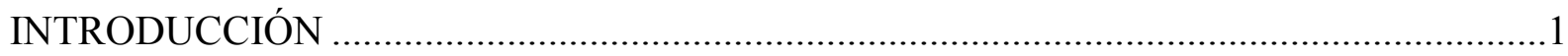

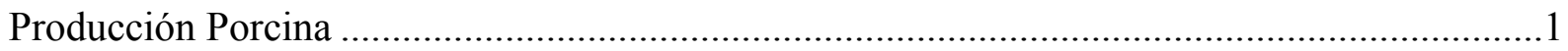

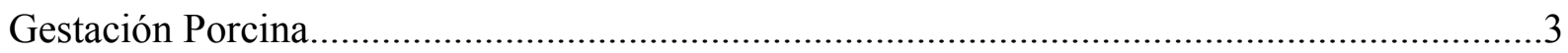

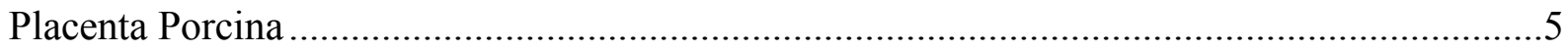

Sistema Inmune

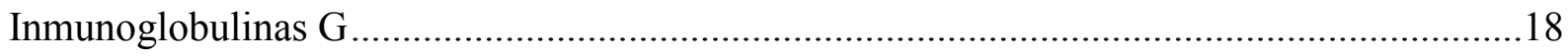

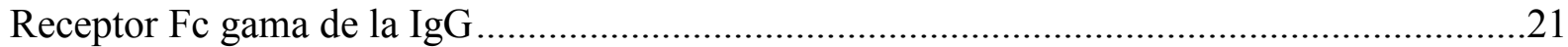

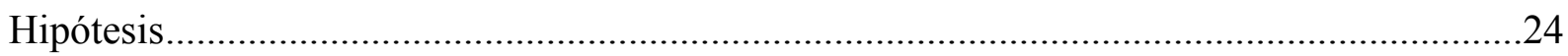

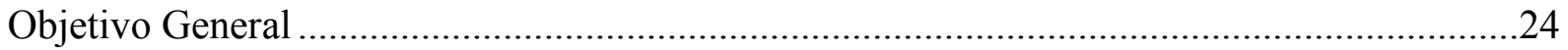

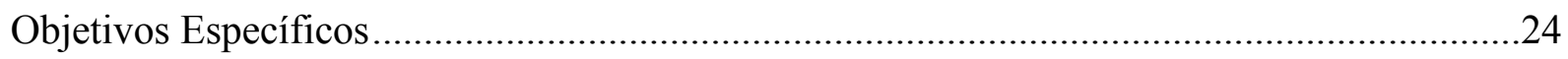

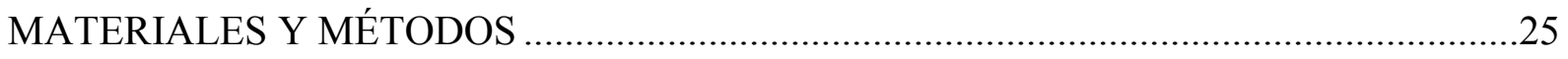

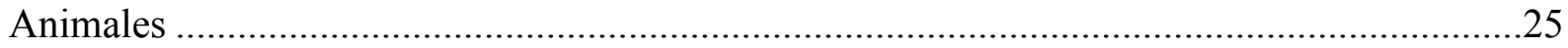

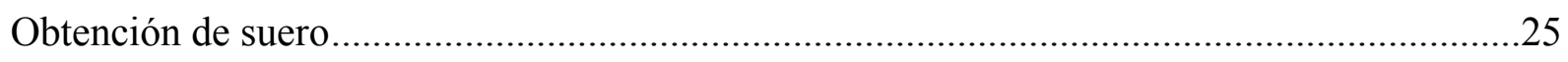

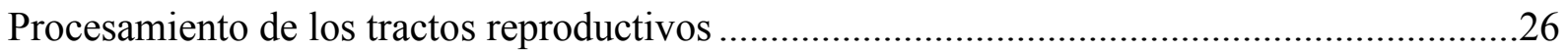


Determinación del período de gestación .26

Procesamiento de la placenta y del útero para estudios histológicos .26

Obtención de homogenatos de placenta porcina materna, fetal y de útero no gestante porcino

Detección de IgG y del receptor de Fc gama de la IgG mediante una

técnica de Inmunohistoquímica. .27

Determinación de IgG simétrica e IgG asimétricas

Cuantificación de proteínas.

Determinación de proteínas totales y albúmina en homogenatos de placenta porcina, materna, fetal y de útero no gestante porcino

Determinación de proteínas totales y albúmina en sueros 32

Determinación de IgG mediante un método inmunoturbidimétrico 33

Determinación de IgG mediante inmunodifusión radial. .34

Análisis estadístico 35

RESULTADOS .36

Estructura de la placenta y del útero: análisis microscópico. .36

Expresión de IgG en diferentes períodos gestacionales y en útero no gestante.

Expresión del receptor Fc gama de $\operatorname{IgG}$ .42

Determinación de Ac IgG asimétricos.

Determinación de Ac IgG asimétricos en suero.

Determinación de Ac IgG asimétricos en homogenato de placenta materna.

Determinación de Ac IgG asimétricos en homogenatos de placenta fetal..... .50

Cuantificación de proteínas totales, albúmina y de $\operatorname{IgG}$ 
Cuantificación de Proteínas Totales, Albumina y de IgG en suero

Correlación y regresión lineal entre IgG Inmunodifusión Radial e IgG

Inmunoturbidimetría

Cuantificación de Proteínas Totales y de IgG Inmunoturbidimetría en homogenatos

placentarios maternos.

Cuantificación de Proteínas Totales y de IgG Inmunodifusión Radial en

homogenatos placentarios maternos

Cuantificación de Proteínas Totales y de IgG Inmunoturbidimetría en homogenatos

placentarios fetales

Cuantificación de PrT y de IgG Inmunodifusión Radial en homogenatos

placentarios fetales .62

DISCUSIÓN .64

CONCLUSIONES .77

BIBLIOGRAFÍA 79

ANEXO 1 .95

ANEXO 2. 


\section{PRESENTACIONES EN CONGRESOS}

1. Estudio Preliminar de Residuos Glicosilados en Tejido Placentario Porcino a Término. Autores: Garro A, Lacolla D, Gastaldo M, Riesco O, Yaful G, Williamson D, Hernández M, Corredera C, Koncurat M. 2das Jornadas de Ciencia y Técnica. Facultad de Ciencias Veterinarias. Universidad Nacional de La Pampa. Diciembre de 2001.

2. Determinación de IgG porcinas por inmunodifusión radial utilizando antisueros humanos. Autores: Koncurat M, Riesco O, Garro A, Yaful G, Williamson D, Lacolla D. Memorias XIV Reunión Anual Científico Técnica. Villa Gral Belgrano, Córdoba. ISSN 1514-8378. Noviembre 2002.

3. Detección de inmunoglobulina G en suero, tejido y extractos placentarios porcinos. Autores: Koncurat M, Garro A, Yaful G, Williamson D, Lacolla D, Riesco O. XLVII Reunión Anual de la SAIC y L Reunión Anual de la SAI. Sociedad Argentina de Inmunología. Revista MEDICINA vol.62 No 5, 2002. ISSN 0025.7680.

4. Presencia de Inmunoglobulinas Maternas sobre la placenta porcina a término. Autores: Koncurat M, Riesco O, Garro A, Yaful G, Lacolla D. I Congreso Latinoamricano de Suinocultura. Libro de Resúmenes. Foz do Iguacu. PR, Brasil. Octubre 2002.

5. IgG in Serum, Tissue and Placental Extracts at Different Times During Swine Pregnancy. Autores: Koncurat M, Riesco O, Garro A, Yaful G, Williamson D, Lacolla D. $6^{\circ}$ Congreso Latinoamericano de Inmunologia, La Habana, Cuba. Diciembre de 2002.

6. Humoral Immune response during the porcine gestation. Autores: Yaful G, Riesco O, Garro A, Williamson D, Bruni M, Alonso G, Lacolla D, Koncurat M. IX World Conference on Animal Production. XVIII Reuniao da Associacao Latinoamericana de Producao Animal. Proceedings Contributed Papers Abstracts. Porto Alegre. Rs. Brasil. October 26-31/ 2003. 
7. Detección de Inmunoglobulina G en sueros, tejidos y extractos placentarios porcinos. Koncurat M, Riesco O, Garro A, Yaful G, Lacolla D, Bruni M, Alonso G, Williamson D. Revista Ciencia Veterinaria. Facultad de Ciencias Veterinarias. Universidad Nacional de La Pampa. Vol. 5 No 1 Año 2003. ISSN. 1516-1883. p. 1-7.

8. Incidence of Humoral Immune Response During The Porcine Gestation. Autores: Wi1liamson D, Yaful G, Riesco O, Garro A, Alonso G, Bruni M, Lacolla D y Koncurat M. Libro de Resúmenes: Biocell, 28 (2), 2004. ISSN 0327-9545. p. 181.

9. Preliminary report of asymmetrical IgG in porcine serum. Autores: Garro A, Gentile T, De León R, Koncurat M. Libro de Resúmenes: I Taller de Interacción Materno-Fetal: de la Fisiología a la Patología. Facultad de Medicina. Universidad de Buenos Aires. Argentina. Noviembre de 2005. p. 18.

10. Presencia de IgG asimétricas en sueros durante la gestación porcina. Autores: Garro A, Gentile T, De León R, Williamson D, Koncurat M. Libro de Memorias IV Jornadas de Ciencia y Técnica. Facultad de Ciencias Veterinarias. Universidad Nacional de La Pampa. Noviembre de 2005.

11. Determinación de IgG asimétricas en sueros de hembras preñadas en diferentes períodos gestacionales. Autores: Garro A, Gentile T, De León R, Koncurat M. Libro de Memorias V Congreso de Producción Porcina del Mercosur. VIII Congreso Nacional de Producción Porcina. XIV Jornadas de Actualización Porcina. Córdoba, Argentina. Mayo 2006. p. 266.

12. Detección de IgG Porcina en Tejidos Placentarios: Estudio Preliminar. Autores: Garro A, Gómez B, Gentile T, Koncurat M. XX Jornadas Científicas Asociación de Biología de Tucumán. Tafí del Valle. Tucumán. Argentina. Septiembre 2006. p. 256. 
13. Detección del Receptor Fc de IgG en placenta porcina. Autores: Garro A, Gómez B, Alonso G, Hernández M y Koncurat M. I Reunión Conjunta de Sociedades de Biología de la República Argentina. Huerta Grande. Córdoba, Argentina. Agosto 2007. p. 48.

14. IgG and Fc Receptor in porcine placenta. Autores: Garro A, Gómez B, Alonso G, Hernández M y Koncurat M. III Latin - American Symposium on Maternal - Fetal Interaction and placenta: Basic \& Clinical Research. Los Cocos. Córdoba, Argentina. Noviembre 2007. p. 89-90.

15. Detección del receptor Fc de IgG en placenta porcina. Autores: Garro A, Gómez B, Gentile T y Koncurat M. Libro de Memorias de la V Jornada de Ciencia y Técnica. Facultad de Ciencias Veterinarias. UNLPam. Noviembre 2007. p. 16.

16. Detección de IgG porcina en tejidos placentarios. Autores: Garro A, Gómez B, Gentile T y Koncurat M. Libro de Memorias de la V Jornada de Ciencia y Técnica. Facultad de Ciencias Veterinarias. UNLPam. Noviembre 2007. p. 17.

17. Detection of IgG - Fc Receptor in Porcine Placenta. Autores: Garro A, Gómez B, Alonso G, Bruni M, Hernández M, Koncurat M. Biocell 2008, vol 32(1) ISSN 0327-9545 (print). ISSN 1667-5746 (electronic). p. 114.

18. Detección del receptor Fc de IgG durante la placentación porcina. Autores: Garro A, Gómez B, Hernández M, Koncurat M. XI Congreso Argentino De Ciencias Morfológicas, I Congreso Internacional De Educación e Investigación en Ciencias Morfológicas. I Encuentro De Histotecnólogos. Córdoba. 14-16 de Mayo de 2008.

19. Expresión del receptor Fc de Ig.G en placentas porcinas de mitad de la Gestación. Autores: Garro A, Gómez B, Koncurat M. IX Congreso Nacional de Producción Porcina. XV Jornadas de Actualización Porcina. Potreros de Los Funes, San Luis, 26-28 de Mayo de 2008. 
20. Determination of Fc Receptor IgG during porcine placentation. Autores: Garro A, Gomez B, Hernández M y Koncurat M. International Journal of Morphology. ISSN 0717-9502. Vol. $26 \mathrm{~N}^{\mathrm{o}} 3.2008$.

21. Presencia del receptor Fc de $\operatorname{IgG}$ en las placentas porcinas durante distintos periodos gestacionales. Autores: Garro A, Gómez B, Koncurat M. Memorias de la 6ta Jornadas de Ciencia y Técnica. Facultad de Ciencias Veterinarias. UNLPam. Vol. 1 No 1. ISSN: 18525725. Agosto 2009.

22. Determinación de Anticuerpos Asimétricos en Extractos Porcinos. Autores: Garro A, Gentile T, De León R, Koncurat M. Libro de resúmenes XXVII Jornadas Científicas. Asociación de Biología de Tucumán. Octubre 2010.

23. Determinación de Anticuerpos Asimétricos en Extractos Placentarios Porcinos. Autores: Garro A, Gentile T, De León R, Koncurat M. Libro de Resúmenes. III Jornadas Asociación de Inmunología Veterinaria. Noviembre 2010.

24. Inmunoglobulinas $\mathrm{G}$ Asimétricas en sueros y extractos placentarios maternos porcinos. Garro A, Gentile T, De León R y Koncurat M. IV Jornadas Asociación Argentina de Inmunología Veterinaria. Río Cuarto. Córdoba. Diciembre 2011.

25. Anticuerpos IgG Asimétricos durante la gestación porcina. Koncurat M, Gentile T, Garro A. XVII Jornadas de Actualización Porcina. XI Congreso Nacional de Producción Porcina. VI Congreso de Producción Porcina del Mercosur. Salta. Agosto 2012.

26. Determinación de IgG por Inmunoturbidimetría en sueros y extractos placentarios porcinos. Garro A, Koncurat M. XVII Jornadas de Actualización Porcina. XI Congreso Nacional de Producción Porcina. VI Congreso de Producción Porcina del Mercosur. Salta. Agosto 2012 . 
27. Asymmetric IgG antibodies in serum and in swine placental extracts. Garro A, Gentile T, Koncurat M. V SLIMP-Latin American Symposium on Maternal Fetal Interaction \& Placenta. IV-LASRI-Latin American Symposium on Reproductive Immunology. Iguazu Falls, Paraná, Brazil. February 2013.

28. Valoración de anticuerpos IgG asimétricos en suero y extractos placentarios porcinos. Garro A, Gentile M, Koncurat M. XXIII Reunión de la Asociación Latinoamericana de Producción Animal. IV Congreso de Producción Animal. La Habana, Cuba. Noviembre 2013.

29. Estrógenos e Inmunoglobulinas G Asimétricas en muestras de suero sanguíneo en distintos períodos de la gestación porcina. Garro A, Koncurat M. VII Congreso de Producción Porcina del Mercosur. XII Congreso Nacional de Producción Porcina. XVIII Jornadas de Actualización Porcina. Agosto 2014. 


\section{PUBLICACIONES}

1. Garro AC, Gentile MT, Koncurat MA. Valoración de Anticuerpos IgG asimétricos en suero sanguíneo y extractos placentarios porcinos. Arch Latinoam Prod Anim. 2014; 22 (3-4): 87-92. ISSN 1022-1301.

2. Garro A, Hernández M, Garcia M, Koncurat M. Inmunoglobulina G y su receptor Fc durante la placentación porcina. Red Vet.2014; 15 (12):1-14. 


\section{ABREVIATURAS}

Alb: Albúmina.

Ac: Anticuerpos.

Ag: Antígenos.

CMH: Complejo Mayor de Histocompatibilidad.

Con-A: Concanavalina A.

DE: Desvío estándar.

DO: Densidad Óptica.

ELISA: Enzimainmunoanálisis.

EE: Error estándar.

Fc: Factor cristalizable.

FcRn: Receptores Fc neonatales.

HoPF: Homogenato de placenta porcina fetal.

HoPM: Homogenato de placenta porcina materna.

HoPP: Homogenato de placenta porcina.

HoU: Homogenato de útero no preñado porcino. 
HRP: Peroxidasa de rábano picante.

IDR: Inmunodifusión radial.

IFM: Interfase feto-materna.

IgG: Inmunoglobulina G.

IHQ: Inmunohistoquímica.

IL: Interleuquina.

PBS: Solución salina tamponada.

PrT: Proteínas totales.

SLA: Antígenos leucocitarios suinos.

Turb: Inmunoturbidimetría. 


\section{LISTA DE TABLAS}

\section{Tabla}

1 Expresión de IgG en útero no gestante y en placentas de diferentes períodos gestacionales

2 Expresión del Receptor Fc gama de la IgG en útero no gestante y placentas de diferentes períodos gestacionales

3a. Porcentaje de anticuerpos IgG asimétricos en sueros en cerdas vacías (0) y preñadas en diferentes períodos gestacionales

3b. Porcentaje de anticuerpos IgG asimétricos en homogenatos de placenta materna en diferentes períodos gestacionales. .95

3c. Porcentaje de anticuerpos IgG asimétricos en homogenatos de placenta fetal en diferentes períodos gestacionales.

4. Porcentaje de anticuerpos IgG asimétricos en sueros de cerdas preñadas (P) y vacías $(0)$ .96

5. Concentración de anticuerpos $\operatorname{IgG}$ asimétricos en sueros de cerdas vacías y en sueros de cerdas en diferentes períodos gestacionales .97

6. Concentración de anticuerpos IgG asimétricos en HoU y en HoPM de cerdas en 
diferentes períodos gestacionales

7. Concentración de anticuerpos IgG asimétricos en HoPF de cerdas en diferentes

períodos gestacionales .98

8. Concentración de PrT en sueros de cerdas vacías (0) y en los diferentes períodos

gestacionales .99

9. Concentración de Alb en sueros de cerdas vacías (0) y en los diferentes períodos

gestacionales .99

10. Concentración de IgG sérica determinada mediante inmunoturbidimetría (Turb)

en cerdas vacías (0) y preñadas en diferentes períodos gestacionales 100

11. Concentración de IgG, mediante IDR, en sueros de cerdas vacías (0) y preñadas en distintos períodos gestacionales 100

12. Concentración de PrT en suero entre cerdas vacías y preñadas .101

13. Concentración de Alb en suero entre cerdas vacías y preñadas 101

14 Concentración de IgG (Turb) en suero entre cerdas vacías y preñadas 101

15. Concentración de IgG (IDR) en suero entre cerdas vacías y preñadas..... .102

16. Concentración sérica de PrT entre cerdas vacías y preñadas en los períodos gestacionales estudiados 102 
17. Concentración sérica de Alb entre cerdas vacías y preñadas en los períodos gestacionales estudiados 102

18. Concentración sérica de IgG (Turb) entre cerdas vacías y preñadas en los períodos gestacionales estudiados 103

19. Concentración sérica de IgG (IDR) entre cerdas vacías y preñadas en los períodos gestacionales estudiados .103

20. Concentración de PrT en extractos uterinos en cerdas vacías y en extractos placentarios maternos en cerdas de diferentes períodos gestacionales 104

21. Concentración de IgG (Turb) en extractos uterinos en cerdas vacías y en extractos placentarios maternos en cerdas de diferentes períodos gestacionales 104

22. Concentración de PrT en extractos placentarios maternos en cerdas vacías preñadas 105

23. Concentración de PrT en HoU de cerdas vacías y en HoPM de los diferentes períodos gestacionales 105

24. Concentración de IgG (Turb) en homogenatos de útero de cerdas vacías y en homogenatos de extractos placentarios maternos. 105

25. Concentración de IgG (Turb) en extractos placentarios maternos en cerdas vacías 
y en los diferentes períodos gestacionales 106

26. Concentración de IgG (IDR) en extractos placentarios maternos en cerdas vacías vs 95-114 días de gestación 106

27. Concentración de IgG (IDR) en homogenato de útero no gestante y en extractos placentarios maternos de 95-114 días de gestación 107

28. Concentración de PrT en extractos placentarios fetales 107

29. Concentración de IgG (Turb) en extractos placentarios fetales 107

30. Concentración de $\operatorname{PrT}(\mathrm{mg} / \mathrm{dl})$ en extractos placentarios fetales en los períodos gestacionales estudiados 108

31. Concentración de IgG (Turb) en extractos placentarios fetales en los períodos gestacionales estudiados 108

32. Concentración de IgG (IDR) en extractos placentarios fetales de 95-114 días de gestación 


\section{LISTA DE FIGURAS}

\section{Figura}

1. Eventos que ocurren durante la implantación del conceptus en especies no invasivas y adecidua. 7

2. Eventos que ocurren durante el inicio de la gestación en el cerdo, desde la fecundación hasta el proceso de elongación del conceptus. .8

3. Placenta fetal de cerda \pm 40 días de gestación .......................................................11

4. Estructuras placentarias conteniendo un feto de 40 días ..........................................11

5. Desarrollo de los órganos fetales durante la gestación en la especie porcina ...............14

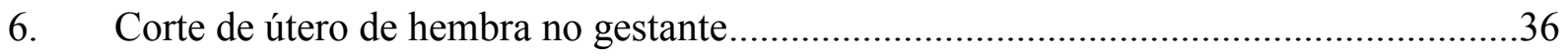

7. Placenta de 30 días de gestación. Inmunomarcaje positivo a IgG...............................38

8. Placenta fetal de 30 días de gestación. Inmunomarcaje positivo a IgG en vellosidades trofoblásticas .38

9. Placenta fetal de 30 días de gestación. Inmunomarcaje positivo a IgG en células epiteliales de glándulas maternas..... .39

10. Placenta fetal de 65 días de gestación. Inmunomarcaje positivo a IgG en vellosidades trofoblásticas .40

11. Interfase feto materna de 65 días de gestación. Inmunomarcaje positivo a IgG 40

12. Placenta fetal a término. Inmunomarcaje positivo a IgG 
13. Placenta fetal a término. Inmunomarcaje positivo a $\mathrm{IgG}$

14. Útero no gestante

15. Placenta materna de 30 días de gestación. Inmunoreacción a Fc gama en

vellosidades maternas 43

16. Placenta fetal de 30 días de gestación. Inmunomarcación positiva a Fc gama .43

17. Placenta fetal de 70 días de gestación. Inmunomarcación positiva a Fc gama 45

18. Placenta fetal de 70 días de gestación. Inmunomarcación positiva a Fc gama 45

19. Placenta a término. Inmunomarcación positiva a Fc gama en vellosidades fetales .46

20. Placenta a término. Inmunomarcación positiva a Fc gama en vellosidades .46

21. Porcentaje de anticuerpos IgG asimétricos en sueros en función de si las cerdas estaban vacías (vac) o preñadas (pre)

22. Porcentaje de anticuerpos IgG asimétricos en muestras de suero en función de los períodos gestacionales (vacías, 30 días, 65-70 días, 95-114 días). .48

23. Porcentaje de anticuerpos IgG asimétricos en muestras de HoU (vacías) y en muestras de homogenatos placentarios maternos (HoPM) de los períodos gestacionales seleccionados (30 días, 65-70 días, 95-114 días).....

24. Porcentaje de anticuerpos IgG asimétricos en muestras de HoPF en función de los 
períodos gestacionales (30 días, 65-70 días, 95-114 días). .50

25. Concentración de $\operatorname{PrT}(\mathrm{mg} / \mathrm{dl})$ en muestras de suero entre cerdas vacías y preñadas ....52

26. Concentración sérica de PrT (mg/dl) entre cerdas vacías y de diferentes períodos gestacionales (vacías, 30 días, 65-70 días, 95-114 días)

27. Concentración de $\mathrm{IgG}$ (Turb) (mg/dl) en muestras de suero entre cerdas vacías y preñadas

28. Concentración de IgG (IDR) (mg/dl) en muestras de suero entre cerdas vacías y preñadas .55

29. Concentración sérica de $\operatorname{IgG}$ (IDR) en $\mathrm{mg} / \mathrm{dl}$ entre cerdas vacías y de diferentes períodos gestacionales (vacías, 30 días, 65-70 días, 95-114 días)

30. Regresión lineal de IgG (Turb) en función de IgG (IDR) .57

31. Concentración de $\operatorname{PrT}(\mathrm{mg} / \mathrm{dl})$ en hembras vacías $(\mathrm{HoU})$ y en los diferentes períodos gestacionales (30 días, 65-70 días, 95-114 días)

32. Concentración de $\operatorname{IgG}(\mathrm{Turb})(\mathrm{mg} / \mathrm{dl})$ en homogenatos de útero de cerdas vacías (HoU) y en homogenatos de extractos placentarios maternos (HoPM) 60

33. Concentración de IgG (Turb) (mg/dl) en hembras vacías (HoU) y en los diferentes períodos gestacionales (30 días, 65-70 días, 95-114 días). 


\section{TITULO Estudio de la respuesta inmune humoral en la gestación porcina}

PALABRAS CLAVES Cerdo - placenta - IgG - Ac IgG asimétricos - Receptor Fc-gama de IgG

\section{RESUMEN}

La preñez en los mamíferos se atribuye a la regulación del sistema inmune materno por factores placentarios. En el presente trabajo de tesis se estudió la respuesta inmune humoral durante la gestación porcina. Se procesaron 45 tractos reproductivos y se recogieron sueros, placentas y muestras de tejidos placentarios maternos y fetales de 30 días $(\mathrm{n}=17)$; 65-70 días $(\mathrm{n}=9)$ y de 96$114(\mathrm{n}=6)$ días de preñez, así como de útero no gestante $(\mathrm{n}=13)$. Se estudió la presencia de $\operatorname{IgG}$ y su receptor en tejidos placentarios por inmunohistoquímica, se determinó la concentración de Ac IgG asimétricos mediante ELISA de captura y la concentración de IgG en suero y en extractos placentarios porcinos por inmunoturbidimetría e inmunodifusión radial. Se detectó la presencia de IgG y su receptor en tejidos placentarios maternos y fetales a partir de los 30 días de gestación hasta el final de la preñez. En placenta materna se halló positividad a IgG en todos los períodos estudiados, así como en los constituyentes de la placenta fetal, particularmente en las vellosidades que conforman la interfase feto materna. Se observó expresión positiva del receptor Fc gama de las IgG durante toda la preñez, salvo en glándulas uterinas al final de la gestación. En suero no encontramos diferencias significativas en el porcentaje de Ac IgG asimétricos entre cerdas vacías y preñadas, pero sí entre los diferentes períodos gestacionales, hallando disminución de Ac IgG asimétricos a los 30 días de preñez y aumento a los 95-114 días (32 \pm 3 vs 43 \pm 3 , p: 0,01). En homogenatos de placenta materna se observó la mayor concentración de anticuerpos asimétricos a los 65-70 días $(x=44,62)$, descendiendo los valores 
al final de la gestación $(x=13,50)$, mientras que en homogenatos fetales las concentraciones de Ac IgG asimétricos permanecieron constantes durante toda la preñez $(x=43,54)$. Se encontraron diferencias significativas en suero entre cerdas vacías y preñadas en la concentración de IgG/Turb (F: 4,17 y p: 0,0483), con una disminución al final de la preñez; mientras que los valores de IgG/IDR (F: 5,16 y p: 0,0316) fueron mayores a los hallados por turbidimetría (p: 0,1278; $\left.\mathrm{R}^{2}: 0,22\right)$, disminuyendo también al final de la preñez. En conclusión, se halló IgG y su receptor Fc gama sobre cortes histológicos placentarios, tanto maternos como fetales, a partir de los 30 días de preñez, se postula que las IgG serían de origen materno y que por transcitosis alcanzan la interfase feto materna. Se determinó la concentración de Ac IgG asimétricos durante la gestación porcina, no hallándose en suero diferencias significativas entre cerdas vacías y preñadas, probablemente debido al tipo de placenta epiteliocorial y no invasiva que presenta esta especie. Únicamente en los homogenatos de placenta fetal se hallaron valores altos de Ac IgG asimétricos a concentraciones constantes durante la preñez. Se postula que la respuesta inmune humoral que se instala durante la gestación, a través de los Ac IgG asimétricos, protegería al embrión/feto del sistema inmune materno posibilitando una gestación exitosa en porcinos. 


\section{TITLE Study of humoral immune response in swine gestation}

Key Words: Swine - placenta - IgG - asymmetric IgG Ab - IgG Fc gamma receptor

\section{ABSTRACT}

Pregnancy in mammals is attributed to the regulation of the maternal immune system by placental factors. In this thesis the humoral immune response during swine pregnancy was studied. 45 reproductive tracts were processed and sera, placentae and samples of maternal and fetal placental tissues of 30 days $(n=17), 65-70$ days $(n=9)$ and 96-114 $(n=6)$ days of pregnancy as well as non-pregnant uterus $(\mathrm{n}=13)$ were collected. The presence of $\operatorname{IgG}$ and its receptor in placental tissues were studied by immunohistochemistry while asymmetric IgG antibody concentration by capture ELISA and IgG concentration in serum and in porcine placental extracts by immunoturbidimetry and radial immunodiffusion were determined. The presence of $\operatorname{IgG}$ and its receptor in maternal and fetal placental tissues as from 30 days of gestation until the end of pregnancy were detected. IgG positivity in all studied periods was found in the maternal placenta as well as in the components of the fetal placenta, particularly in the villi that make the maternalfetal interface. A positive expression of $\mathrm{IgG} \mathrm{Fc}$ gamma receptor throughout pregnancy, except uterine glands at the end of gestation, was observed. In serum no significant differences in the percentage of asymmetric $\operatorname{IgG~} \mathrm{Ab}$ between empty and pregnant sows were found but between different gestational periods; a decrease in asymmetric $\operatorname{IgG} \mathrm{Ab}$ was found at 30 days of gestation, increasing to $95-114$ days ( $32 \pm 3$ vs $43 \pm 3$, p: 0.01$)$. In homogenates of maternal placenta the greatest concentration of asymmetric antibodies was observed at 65-70 days $(x=44.62)$, the values decreasing at the end of gestation $(\mathrm{x}=13.50)$, while in fetal homogenates asymmetric $\operatorname{IgG}$ $\mathrm{Ab}$ concentrations remained constant throughout pregnancy $(\mathrm{x}=43.54)$. Significant differences were found in serum between empty and pregnant sows in IgG / Turb concentration (F: 4.17, p: 
0.0483), with a decrease at the end of pregnancy, while values of IgG / IDR (F: 5.16, p: 0.0316) were higher than those found by turbidimetry ( $\left.\mathrm{p}: 0.1278, \mathrm{R}^{2}: 0.22\right)$, also decreasing to the end of pregnancy. Concluding, IgG and its $\mathrm{Fc}$ gamma receptor were found in placental histological sections, both maternal and fetal, as from 30 days of pregnancy so it is postulated that IgGs would be of maternal origin and they reach the maternal-fetal interface by transcytosis. The concentration of asymmetric IgG $\mathrm{Ab}$ during porcine gestation was determined, finding no significant differences in serum between empty and pregnant sows, probably due to the type of epiteliochorial, noninvasive placenta seen in this species. Only in fetal placental homogenates high values of asymmetric $\mathrm{IgG} \mathrm{Ab}$ were found at constant concentrations during pregnancy. We postulate that the humoral immune response during pregnancy, through asymmetric $\operatorname{IgG} \mathrm{Ab}$, would protect the embryo / fetus from the maternal immune system enabling a successful pregnancy in pigs. 


\section{INTRODUCCIÓN}

\section{Producción Porcina}

El cerdo (Sus scrofa ssp doméstica) es una especie de mamífero artiodáctilo perteneciente a la familia Suidae. Se distribuye en todo el planeta y constituye la principal fuente de proteínas de origen animal que consume la población mundial (Eguchi-Ogawa y col., 2010).

Los principales productores de carne porcina son China con un 49\%, luego la Unión Europea con 27\% y Estados Unidos con un 10\%, detrás aparecen países como Rusia y Brasil. China es el principal consumidor, con 49.810 miles de tm (USDA, 2011 (United State Department Agriculture), seguido por la Unión Europea y Estados Unidos. En el mundo se consume un promedio de $14,8 \mathrm{~kg}$ de carne porcina por habitante por año, mientras que el consumo de carne de pollo es de 11,4 $\mathrm{kg}$ y el de carne vacuna es de 8,1 kg. En Argentina las estadísticas informan un consumo de cerdo en el año 2010 de 8,06 kg/habitante/año, en el año 2011 de 8,64 kg/habitante por año y en el año 2013 aumentó a 10,40 kg/habitante/año (Ministerio de Agricultura, Ganadería y Pesca, 2014). En nuestro país, durante los años 2005 al 2009 se incrementó el consumo y la exportación de carne porcina, siendo los datos del año 2005 de 230 toneladas de carnes (frescas, procesadas, fiambres, embutidos y chacinados) que aumentó a 800 toneladas en el año 2009 (Ministerio de Agricultura, Ganadería y Pesca, 2011).

Los principales analistas internacionales del sector cárnico sostienen que, en el año 2020, solamente podrán competir como productores de proteína animal aquellos países capaces de autoabastecerse de granos y con reservas de agua potable suficientes (García, 2007). La producción de cerdos de Argentina comienza a transitar un camino de oportunidades que la llevaran al desarrollo y la consolidación (Brunori, 2011). Al sector porcino argentino se le 
presenta una oportunidad, dado el aumento de la tasa de crecimiento poblacional en los países en vías de desarrollo con el consiguiente aumento de necesidades de alimento. Ese mercado internacional presentará mayores requerimientos de productos con altas especificaciones de calidad, en cuanto a presentación, sanidad, seguridad y valor nutricional. El aumento mundial del consumo de carnes magras, relacionado con hábitos de alimentación más saludables, la demanda de carne vacuna insatisfecha, las preferencias crecientes de productos orgánicos y ecológicos, con certificaciones que denoten el respeto en el uso de los recursos naturales, el medio ambiente y el bienestar animal, posicionan a la carne de cerdo como el producto más apropiado a estas exigencias (García, 2007). Nuestro país cuenta con muy buen status sanitario, disponibilidad de materias primas de máxima calidad, suelos, clima adecuados y buena disponibilidad de agua potable. Todos estos factores permitirían desarrollar la actividad respetando el medio ambiente y el bienestar animal y a un costo de producción competitivo a nivel mundial, ya que dispone de tecnología y genética (García, 2007). Según el Ministerio de Agricultura, Ganadería y Pesca, la faena porcina llevada a cabo durante el año 2011 en nuestro país fue de 3.441 .983 cabezas de porcino mientras que en los primeros seis meses del año 2012 los datos son de 1.679 .432 cabezas de ganado porcino faenado. En el centro de nuestro país se encuentra la provincia de La Pampa, durante el año 2010 en nuestra provincia los datos de faena porcina muestran valores de 7.838 cabezas. Cabe consignar que la existencia de cerdos en pie, en nuestra provincia ascendió a 145.014 animales durante el año 2013 (Ministerio de la Producción de la Provincia de La Pampa, Estadística y Censos, 2014).

En la producción porcina, el manejo reproductivo es fundamental para alcanzar índices óptimos, que se traduzcan en una mayor rentabilidad y eficiencia de la inversión. Las pérdidas 
prenatales y postnatales limitan una mayor rentabilidad económica. Así, la mortalidad embrionaria temprana sin causa especifica origina la mayor cantidad de pérdidas, con valores entre un 30\% y un 40\% antes del día 30 de preñez (Pope, 1994; Bazer y col., 2014), aunque en nuestra región, en el norte de la provincia de La Pampa y sur de Córdoba, puede alcanzar hasta un 50\% - 52\% (Bosch y col., 2001). Estos porcentajes conllevan a demarcar una de las variables más importantes de la industria porcina como es el número de partos por cerda por año, y se propone que la forma de incrementar la producción se logrará disminuyendo la alta tasa de muerte embrionaria temprana sin causa específica (Cristofolini, 2010).

Por otro lado, se evidencia un gran interés en el cerdo como objeto de estudio, ya que ha sido una de las especies utilizadas como modelo experimental, dadas las semejanzas anatómicas y fisiológicas con la especie humana y la facilidad de su utilización como animal de experimentación. Estudios sobre alcoholismo, alotrasplantes, diabetes, hipertensión, choque séptico y enfermedad renal han tenido importantes aplicaciones en medicina humana. En los últimos años el interés por el estudio de la inmunología porcina se ha visto estimulado por la posibilidad de usar a la especie porcina como donante de órganos para el trasplante a pacientes humanos (Paños Adillo, 2003).

\section{Gestación Porcina}

La cerda es una hembra poliéstrica continua, ciclando regularmente todo el año en condiciones favorables. Su pubertad ocurre alrededor de los 6 a 7 meses, cuando alcanza un peso corporal de 100 a $110 \mathrm{~kg}$, como resultado de un conjunto de factores que interaccionan; factores internos como genotipo, raza y control neuroendocrino y externos como nutrición, salud, medio 
ambiente y manejo. Su ciclo estral es de aproximadamente 21 días con un rango de 18 a 24 días, hasta la edad de 10 a 12 años. El proestro, período en el que se produce el crecimiento folicular, puede durar alrededor de dos días y se continúa con el estro, período de receptividad sexual de dos a tres días de duración. Siguen luego el metaestro, período de desarrollo inicial del cuerpo lúteo de uno a dos días y el diestro, período de actividad del cuerpo lúteo maduro. Su ovulación ocurre espontáneamente de 36 a 44 horas después del inicio del estro y la tasa de ovulación media es de 13,5 ovocitos liberados por ambos ovarios por celo, en primerizas, y de 21,4 en adultas (Trolliet, 2005), existiendo un intervalo de tiempo entre la expulsión del primer óvulo y la expulsión del último, lo que lleva a una fertilización heterogénea que origina embriones con diferente grado de desarrollo que comparten el mismo espacio uterino (Pope y col., 1988; Escobar Medina, 2004).

La gestación es el período de desarrollo intrauterino embrionario-fetal en el que ocurre la nutrición del feto en crecimiento y las adaptaciones maternas para lograr un proceso exitoso. El período de gestación en la cerda dura \pm 114 días, considerando día cero el día del servicio.

La sobrevida de los embriones y de los fetos porcinos depende de diferentes parámetros, tales como el flujo de sangre que llega al útero, la ubicación del conceptus, el suministro adecuado de nutrientes, la capacidad del órgano para albergar a los embriones y fetos, el número de partos que ha llevado a término y la efectividad de la placenta (Van der Lende y Van Rens, 2003).

El mecanismo celular y molecular que se instala desde el inicio de la preñez depende de una serie de complejas interacciones bioquímicas y celulares, descriptas por Short en 1969 (citado por Hafez y Hafez, 2003), que se conoce como "reconocimiento materno de la preñez". En 
el organismo y en el aparato reproductor de la hembra se producen los cambios inducidos por las hormonas gestacionales, por las células del sistema inmune y por un conjunto de moléculas, particularmente las citoquinas, que regulan la respuesta inmune de la madre, permitiendo la sobrevida del aloinjerto fetal y una gestación exitosa (Engelhardt y King, 1996; Ramsoondar $y$ col., 1999; Joyce y col., 2008, Gómez Esperanza, 2007, Geneser, 2008; Tizard, 2009).

\section{Placenta porcina}

La placenta porcina es epiteliocorial, difusa, adecidua, plegada y no invasiva (Amoroso, 1952; Perry, 1981; Wooding y Burton, 2008). Presenta una estrecha asociación entre los tejidos maternos y fetales (Engelhardt y King, 1996), con capas que forman la barrera placentaria que permanece completa durante la preñez, y solo el epitelio uterino toma contacto con el trofoblasto, por esta razón es epiteliocorial y no invasiva. Es adecidua porque no hay pérdida de tejidos uterinos en el momento del parto ya que las vellosidades se introducen en la mucosa como los dedos en un guante (Senger, 2003). Es difusa porque las vellosidades placentarias se distribuyen en todo el corion, formando un corion frondoso y proporcionando una amplia área feto-materna de intercambio. El saco coriónico conforma pliegues macroscópicos, de diferente tamaño, que se interdigitan con estructuras complementarias del lado endometrial, originando los pliegues secundarios, conocidos como vellosidades, que aumentan aún más el área de superficie y por, ende, la capacidad de intercambio materno fetal; la presencia de los pliegues le confiere la característica de ser una placentación de tipo plegada.

Alrededor de 48 horas después de la fecundación, el cigoto ingresa a los cuernos uterinos en la etapa de cuatro células. A los 4-5 días después de la fertilización, madura a blastocisto 
compuesto por una pared de epitelio simple, denominada trofoblasto que formará la placenta fetal y una masa celular interna, el embrión propiamente dicho. Así, la placenta porcina presenta una estructura bimodal, con componentes fetales y con componentes maternos que aporta el útero preñado.

El conceptus comienza a implantarse en la superficie uterina hacia el día 11-12 de preñez, completándose esta etapa los días 17-18 (Dantzer, 1985), período que se conoce como "ventana de implantación“. Los estrógenos y la progesterona influencian las interacciones entre el útero y el conceptus durante este período peri-implantacional, favoreciendo la adhesión del trofoblasto al epitelio luminar uterino, proceso que permite la implantación y la placentación (Ka y col., 2007; Joyce y col., 2008). Estas hormonas esteroideas actuarían regulando la diferenciación y función de las células uterinas (Franczak y Kotwica, 2008). El conceptus libera estrógenos que actúan como señal del reconocimiento de la preñez (Bazer y Thacher, 1977; Joyce y col., 2007) lo que permite el anclaje de los embriones al epitelio endometrial. De esta manera los embriones se distribuyen a lo largo de ambos cuernos uterinos sobre el mesometrio. El anclaje microvelloso consiste en proliferaciones epiteliales del endometrio que contactan con el trofoblasto conformando interdigitaciones microvellosas (Figura 1, Bazer y col., 2009a). 


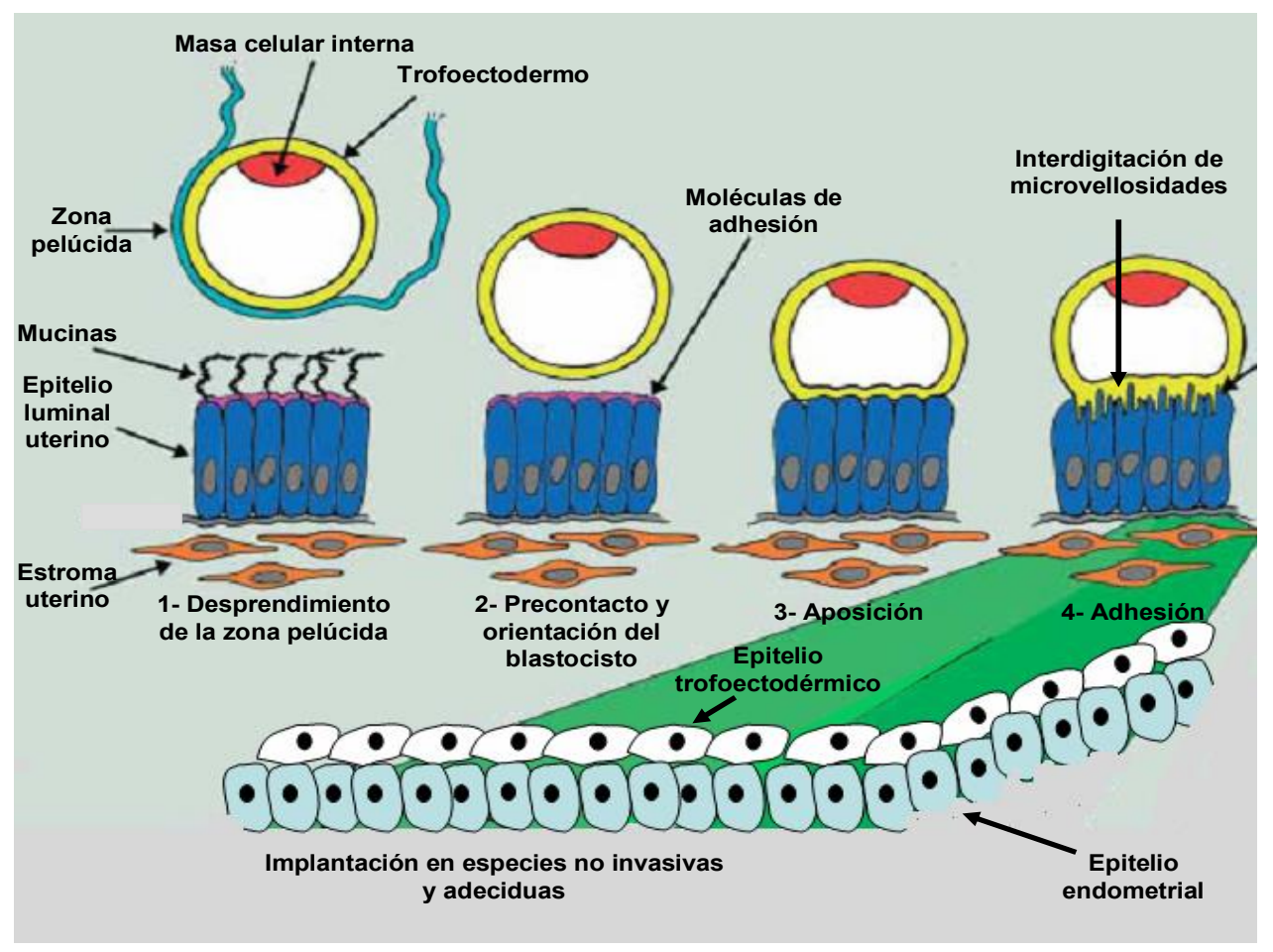

Figura 1: Eventos que ocurren durante la implantación del conceptus en especies no invasivas y adeciduas. Modificado de Bazer y col., 2009a.

La implantación involucra las fases de contacto o aposición del epitelio uterino con el trofoectodermo, la adhesión y el anclaje microvelloso (Dantzer y Leiser, 1993a; Dantzer y Bjorkman, 1994; Koncurat, 2003; Bazer y col., 2009a). Mientras sucede este proceso el conceptus inicia el proceso de elongación, cambiando de una forma esférica de $1 \mathrm{~cm}$ de diámetro a una forma larga, filamentosa, tubular y plegada. El blastocisto se alarga considerablemente, hasta alcanzar unos $100 \mathrm{~cm}$ de longitud, reorganizándose y remodelándose el trofoblasto durante unas 4 a 5 horas entre el día 11 y 12 de gestación (Wilson y col., 2000; Bazer y col., 2009b; Bazer y col., 2014, (Figura 2). 


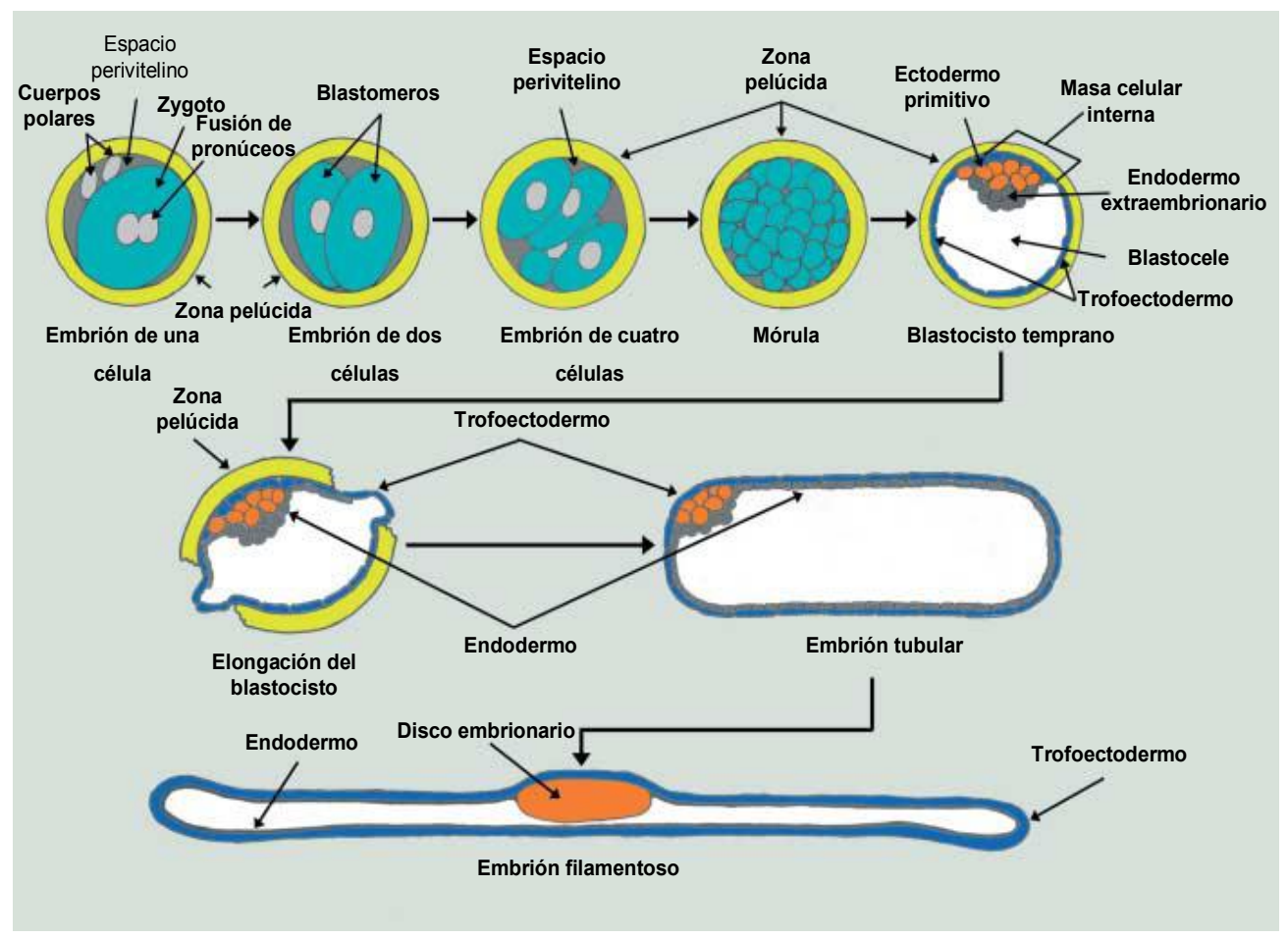

Figura 2: Eventos que ocurren durante el inicio de la gestación en el cerdo, desde la fecundación hasta el proceso de elongación del conceptus. Modificado de Bazer y col., 2014.

Las pérdidas embrionarias suelen ser altas durante el proceso de elongación del blastocisto. Diversas moléculas participan en este proceso, pero no hay una clara descripción de los factores y de los mecanismos involucrados (Blomberg y col., 2008). La expansión del trofoblasto permite un incremento de la superficie de la placenta, una mayor comunicación entre el conceptus y la madre y un intercambio de nutrientes esencial para la sobrevida embrionaria (Stroband y Van der Lende, 1990; Vallet y Freking, 2007).

La membrana plasmática del trofoblasto posibilita la difusión de algunos elementos que permiten su desarrollo. Las elevadas demandas de oxígeno por parte del conceptus se suplen mediante un mecanismo de difusión bajo gradiente de presión, por lo que el espesor de la barrera placentaria condiciona la eficiencia en el proceso. Lo mismo ocurre con el pasaje de agua y 
electrolitos. La distancia entre la circulación materna y fetal disminuye cuando el área de las superficies vasculares aumenta, lo cual facilita el transporte transcelular y paracelular de las partículas (Song y col., 2010).

Por otro lado, el proceso de adenogénesis endometrial consiste en la diferenciación y construcción del epitelio glandular en el estroma uterino mediante invaginaciones, extensos enrollamientos tubulares y bifurcaciones de las glándulas. En gestaciones de animales domésticos y humanos, la existencia de defectos en la morfogénesis de las glándulas del endometrio durante el desarrollo y crecimiento uterino también causan un aumento de las pérdidas embrionarias (Burton y col., 2002; Spencer y Bazer, 2004a; Spencer y Bazer 2004b), debido a la importancia de las mismas en la nutrición fetal durante la gestación.

Las glándulas endometriales adquieren una apariencia tubular, espiralada con un lumen estrecho en los inicios de la gestación mientras que hacia la mitad de la preñez se dilatan, aumentando su actividad secretora hasta la finalización de la preñez porcina (Gray y col., 2001; Cristofolini, 2010).

En la interfase feto materna, zona donde se produce un íntimo contacto entre los epitelios materno y fetal, la placenta porcina presenta regiones areolares en donde el trofoblasto se contacta con las glándulas uterinas mediante estructuras especializadas llamadas areolas y regiones interareolares en donde se observa el trofoblasto unido al epitelio uterino. Las areolas son prominencias proliferativas del trofoblasto, enfrentadas a cavidades de las glándulas uterinas, histológicamente discernibles a partir de los 15 días de preñez (Dantzer, 1985).

En las regiones interareolares se realiza el intercambio de gases y la nutrición hemotrófica por parte del trofoblasto, debido a la proximidad entre los capilares sanguíneos maternos y fetales 
(Dantzer y Leiser, 1993b; Johansson y col., 2001). En las regiones areolares es donde ocurre el transporte materno fetal de macromoléculas durante la gestación, que constituye la nutrición histiotrófica (Koncurat, 2003a; Merkis y col., 2005). El complejo aréola-glándula es la principal vía de transferencia de hierro desde la madre al feto (Dantzer y Bjorkman, 1994).

Se postula que a través de las areolas las secreciones del epitelio superficial y del epitelio glandular del útero, así como las moléculas provenientes del suero materno, por trasudación, penetran en las glándulas uterinas y en el epitelio luminal, para luego ser absorbidas y transportadas, por mecanismos de pinocitosis en fase acuosa, a través de la placenta corioalantoidea, para finalmente ser liberadas en la circulación fetal (Dantzer y Leiser, 1993a). La placenta de cada feto/embrión posee alrededor de 8.500 areolas y su cantidad se ha correlacionado con el peso fetal (Wooding y Burton, 2008). Recientemente, se ha postulado que el tipo de transporte por las areolas placentarias sería similar a los mecanismos a través de los cuales las inmunoglobulinas del calostro atraviesan el epitelio de los enterocitos, para luego ser liberadas en el sistema circulatorio del neonato a fin de establecer la inmunidad pasiva en los lechones (Song y col., 2010).

En la placenta porcina, hacia el día 40 de la gestación, se distinguen tres regiones que son anatómica e histológicamente diferentes, las extremidades avasculares del saco corio-alantoideo, la zona paraplacentaria; constituida por las membranas extra-embrionarias y la zona placentaria ubicada en la parte central del saco y que contiene el embrión rodeado por la membrana corioalantoidea. Una constricción anular marca la unión de los apéndices avasculares de la placenta con la zona paraplacentaria, a veces, los apéndices avasculares pueden superponerse con los apéndices de las placentas adyacentes. En la zona paraplacentaria se encuentran los vasos 
sanguíneos corio-alantoideos, dispuestos en forma paralela al eje longitudinal del saco coriónico (Figura 3 y 4).

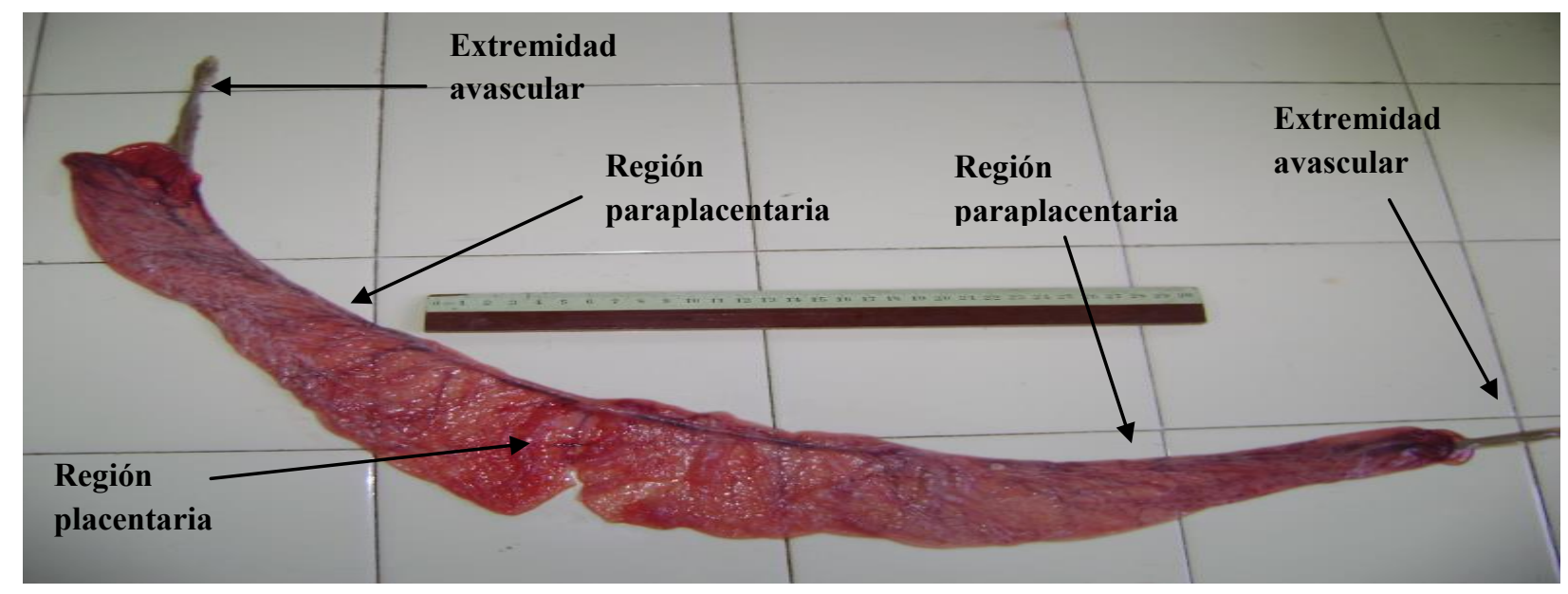

Figura 3: Placenta fetal de cerda de \pm 40 de gestación.

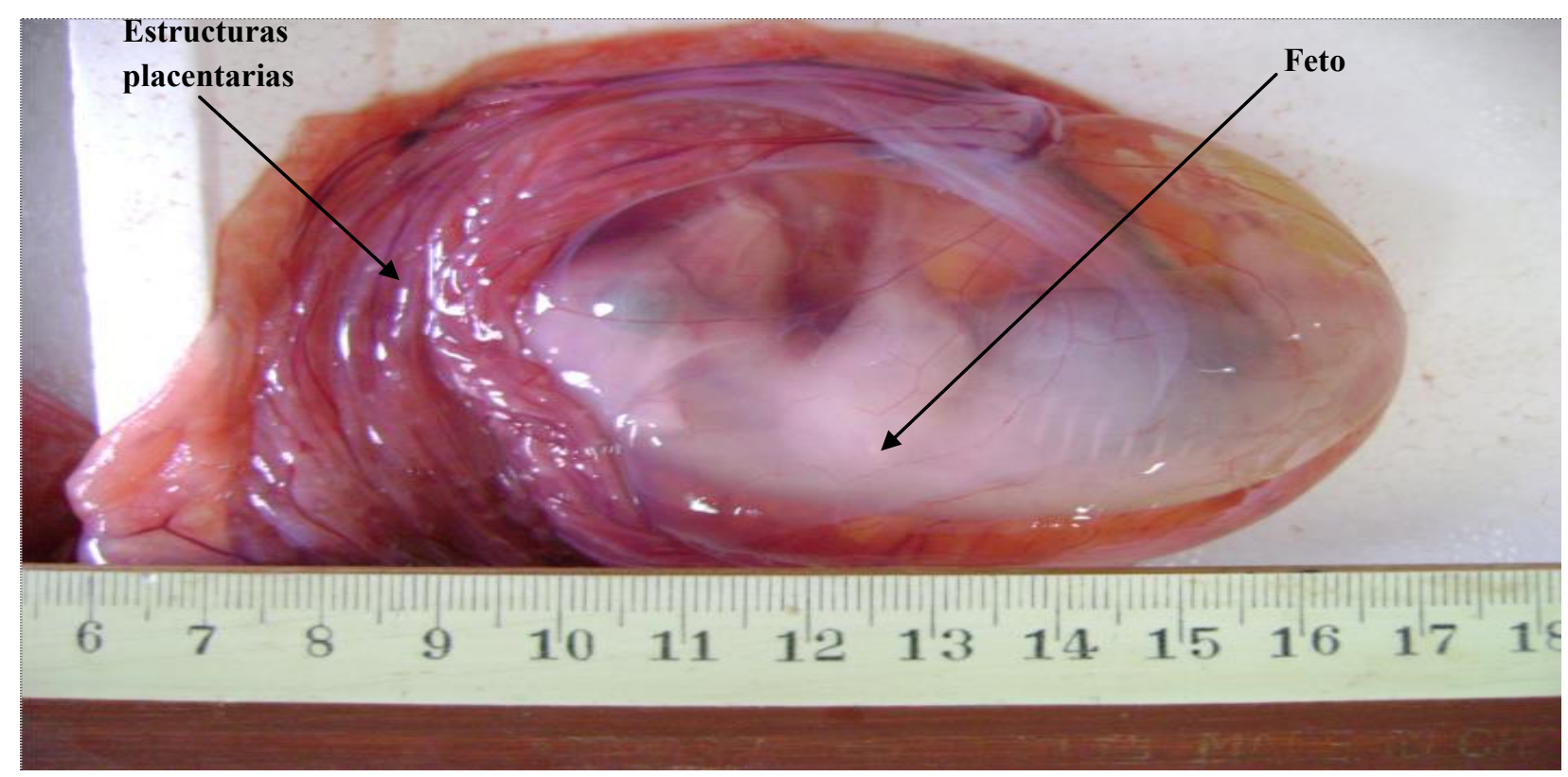

Figura 4: Estructuras placentarias conteniendo un feto de 40 días. 
El crecimiento placentario es medido en peso, y se ha comprobado que se produce un incremento exponencial entre los días 20 y 60 de la gestación. Entre los días 60 y 110 de la gestación, el crecimiento se mantiene en forma de meseta y antes del término de la preñez se produce un nuevo incremento (Wilson y Ford, 2001; Merkis y col., 2005; Bazer y Johnson, 2014). En nuestro laboratorio hemos observado que la apoptosis y la actividad mitótica permiten las reestructuraciones a nivel celular (Cristofolini, 2010; Merkis y col., 2010).

\section{Sistema inmune}

El sistema inmune porcino presenta diferencias morfológicas y funcionales con respecto a otros mamíferos, comprende un conjunto de órganos y estructuras diversas en cuanto a naturaleza, origen y función, localizados en diferentes lugares del organismo. Su papel es intervenir en los procesos de defensa frente a agentes extraños, memorizarlos para reconocerlos en una segunda infección y, además, mantener la integridad preservando las estructuras propias del organismo (Gómez y col., 2007; Tizard, 2009). Durante la morfogénesis del sistema inmune en el cerdo se destacan tres etapas; la primera, que comprende desde el día cero de gestación hasta el día 12 abarca el desarrollo del cigoto, la maduración de la mórula y las etapas de blástula; los huevos fecundados atraviesan el oviducto y entran en el útero alrededor de los días 2 al 5 de gestación y hacia el día once el embrión muestra signos de implantación al endometrio. La segunda etapa, corresponde al período embrionario y comprende desde el día 12 al día 32 de la gestación, se destaca por el inicio de la gastrulación y posteriormente por la formación de los órganos básicos primordiales. Además, se constituye la placenta materno-fetal. La tercera etapa, abarca el período fetal de la embriogénesis y comprende desde el día 36 al día 114, se caracteriza 
por el crecimiento fetal, por la formación del sistema linfático, la actividad hematopoyética de la médula ósea y la expansión de los ganglios linfáticos periféricos que se producen entre los días 60 y 90 de gestación (Šinkora y Butler, 2009), (Figura 5).

Desde el punto de vista funcional y morfológico los órganos se clasifican en primarios o centrales y órganos secundarios o periféricos. Los primarios o centrales son los primeros en formarse durante la vida embrionaria y son los responsables de la producción y diferenciación de los linfocitos. En ellos, los linfocitos se capacitan y maduran adquiriendo y expresando los receptores específicos para cada tipo de antígeno capaces de reconocer durante toda su vida. También se lleva a cabo el proceso de selección celular, eliminando por apoptosis clones de linfocitos que reconocen antígenos propios.

Alrededor del día 16 de preñez se observan en el embrión los primeros islotes sanguíneos, pero recién al día 30 se pudieron detectar las primeras células $\mathrm{CD}^{+}$en el timo (Šinkora y Butler, 2009). 

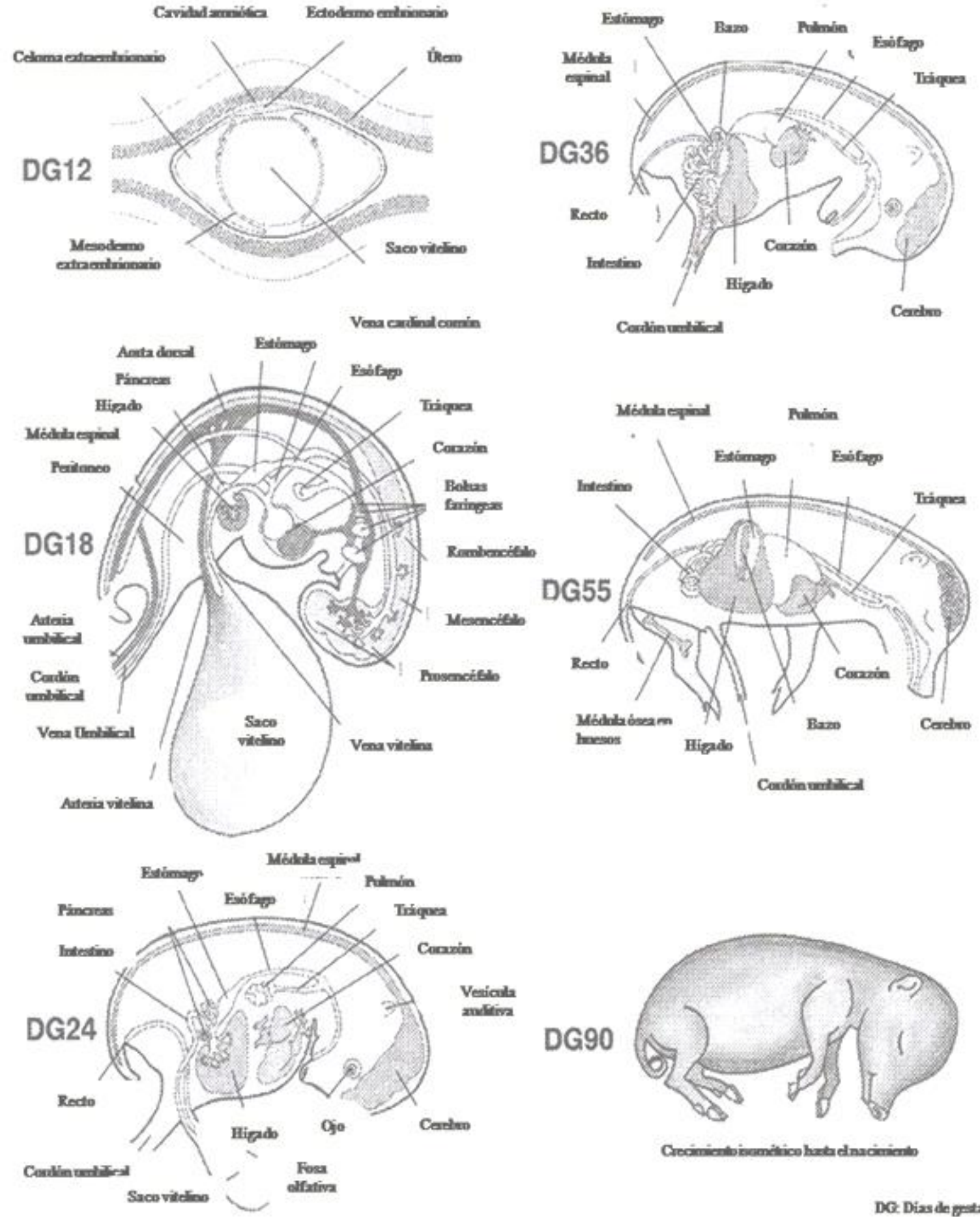

DQ. Dias de gradín

Figura 5: Desarrollo de los órganos fetales durante la gestación en la especie porcina. Modificado de Šinkora y Butler, 2009. 
El sistema linfático se encuentra formado hacia el día 35, momento que marca el fin de la organogénesis, pero los linfocitos son raros hasta el día 45, que es cuando comienza la actividad hematopoyética en la médula ósea. Entre los días 60 y 90 de preñez se produce un crecimiento marcado de los órganos linfáticos (Šinkora y Butler, 2009).

Los linfocitos B fetales se diferencian en los órganos primarios hematopoyéticos; raramente se observan al día 20 en el saco vitelino (que involuciona después de los días 24-27), luego se hallan en el hígado fetal desde los 30 a los 45 días de gestación (Butler y col., 2005; Butler y col., 2006a). Finalmente, se diferencian en la médula ósea hacia el día 65 de gestación, donde representan alrededor del $30 \%$ de las células nucleadas que darán origen a los linfocitos B funcionales portando el receptor de superficie de las células B (Butler y col., 2006b; Butler y Wertz, 2012).

Recién alrededor del día 50 de preñez, células B del bazo y del hígado comienzan a secretar pequeñas cantidades de inmunoglobulinas (Butler y col., 2009a). Los fetos porcinos poseen pequeñas cantidades de inmunoglobulinas $(10-27 \mu \mathrm{g} / \mathrm{ml})$ del tipo $\operatorname{IgG}$, IgM e IgA en sangre después del día 70 de preñez, de las cuales las IgG son el 80\% (Butler y col., 2006b; Eguchi-Ogawa $y$ col., 2010). Durante la vida fetal se produce un cierto nivel de recombinación para producir el cambio de isotipo, las células B transcriben y secretan en el suero estas inmunoglobulinas recombinadas sin que se presente ningún antígeno ambiental durante ese tiempo. Se desconoce si este cambio de las cadenas pesadas implica la formación de centros germinales (Butler y Wertz, 2012).

La mayoría de las células B y T periféricas fetales se generan entre los días 60 y 80 . Estos linfocitos maduros vírgenes se dirigen hacia los órganos y tejidos linfoides secundarios 
periféricos, reconociendo a través de sus receptores de superficie a los antígenos específicos, se activan ante su presencia y se diferencian en células plasmáticas sintetizadoras de inmunoglobulinas (Igs) y en células B de memoria (Šinkora y Butler, 2009; Šinkora y col., 2005).

El timo se localiza en la cavidad torácica, en posición craneal respecto al corazón. Al igual que en todos los animales domésticos, allí proliferan y se diferencian los precursores de los linfocitos T que se formaron en la médula ósea fetal. Muchos mueren por apoptosis, mientras que los sobrevivientes permanecen en el timo durante 4 o 5 días antes de colonizar los órganos linfoides secundarios, donde cumplirán su función en la respuesta inmune.

Los cerdos poseen una estructura invertida de los nódulos linfoides o linfonódulos. En la periferia el tejido linfoideo es difuso y en el centro es nodular, esto se debe a que los vasos linfáticos aferentes penetran por el hilio a diferencia de lo que ocurre en la mayoría de los mamíferos (Rothkötter, 2009).

Según Tizard, 2009, en las placas de Peyer ileocecales porcinas es donde se efectúa la proliferación, maduración y diversificación de linfocitos B en las etapas tardías de la gestación. Están formadas por folículos linfoides que contienen solo linfocitos B, alcanzan su tamaño y madurez máxima antes del nacimiento y protegidas de la presencia de antígenos extraños, por el tipo de placentación. Además, el cerdo puede poseer un segundo tipo de placas constituidas por acumulaciones pequeñas de folículos en el yeyuno con linfocitos B y alrededor de un $30 \%$ de linfocitos T. También, al igual que en otras especies, existen en las paredes del intestino grueso los complejos linfoglandulares, linfocitos intraepiteliales, células $\mathrm{M}$ y células plasmáticas. Sin embargo, Butler y Wertz, 2012, no han encontrado pruebas para postular que las placas de Peyer sean sitios donde se realiza la linfogénesis de los linfocitos B. 
En la reproducción, el sistema inmunológico con sus mecanismos celulares y moleculares juega un rol que aún no se comprende en su totalidad. Hay múltiples antígenos tisulares que difieren entre el feto y la madre y son potencialmente aloantígenos de tejidos reconocibles por el sistema inmune materno (Ye y col., 2008). Por esta razón, surge el interrogante de por qué no se induce una respuesta por parte de las células inmunes maternas hacia esos aloantígenos y de cómo la madre se protege contra agentes microbianos, sin desencadenar una respuesta inmune letal contra los tejidos fetales (Rabinovich, 2004).

Se demostró que los antígenos del Complejo Mayor de Histocompatibilidad, clase I, denominados en cerdos antígenos leucocitarios porcinos, no se detectan sobre la superficie de las membranas extraembrionarias durante la gestación, pero sí se encuentran niveles muy bajos de ARNm específico para las moléculas del Complejo Mayor de Histocompatibilidad en las células y tejidos del endometrio uterino y en los leucocitos maternos provenientes de sangre periférica (Ramsoondar $y$ col., 1999; Tennant $y$ col., 2007).

El estado fisiológico de la preñez asegura que las necesidades maternas y fetales se cumplan, que la madre esté protegida contra antígenos extraños y que a su vez sea tolerante con sus fetos, proceso facilitado por la expresión endometrial de los antígenos leucocitarios porcinos clase II; así las transcripciones de los antígenos leucocitarios porcinos maternos se incrementan en el endometrio durante la implantación del conceptus, lo que permite suponer que es el embrión quien modifica dicha expresión (Edwards y col., 2012).

Durante el primer mes de preñez, cuando el contacto íntimo entre tejidos fetales y maternos se establece, la cantidad de linfocitos maternos uterinos disminuye en el epitelio luminal y se incrementa en el estroma endometrial en los sitios de fijación del conceptus, y sería 
el conceptus quien influenciaría la distribución de los linfocitos $\mathrm{T}$ y NK durante la preñez temprana (Engelhardt y col., 2002a; Engelhardt y col., 2002b; Dimova y col., 2007; Croy y col., 2009).

Como no hay transferencia de inmunoglobulinas desde la madre al embrión / feto, las células fetales porcinas $\mathrm{B}$ son una población naive desarrollándose con influencia idiotípicaantiidiotípica (Butler y col., 2000; Butler y col., 2008; Rothkötter, 2009; Salmon y col., 2009).

\section{Inmunoglobulinas G (IgG)}

Los cerdos, como los ratones y humanos, expresan en mayor cantidad las inmunoglobulinas de la clase IgG, además poseen $\operatorname{IgM}$, IgD, IgE e IgA (Butler y Howard, 2002; Butler y col., 2005; Butler y col., 2009b).

Las IgG son glicoproteínas constituidas por cadenas proteicas pesadas y livianas unidas entre sí por puentes disulfuros; tienen un peso molecular de alrededor de $180 \mathrm{kDa}$. Son moléculas de anticuerpos elaboradas por los linfocitos B; cuando los linfocitos B se diferencian en células plasmasticas las IgG son secretadas a sangre. La IgG es el principal isotipo en el cerdo, constituyendo entre el 80 al $85 \%$ de las inmunoglobulinas en el suero y en el calostro porcino y por esta razón juega un papel primordial en los mecanismos de defensa mediados por anticuerpos (Tizard, 2009; Sánchez Vizcaíno, 2010). Todas las regiones constantes de las cadenas pesadas y 15\% de las cadenas variables están glicosiladas (Pennimpede y col., 2004) por lo que presentan diferencias entre los isotipos. Estos restos glicosídicos originarían cambios en sus propiedades biológicas, fundamentalmente sobre la capacidad de unión al antígeno y el tipo de respuesta inmune que se implementa. La IgG, debido a su tamaño, puede extravasarse fácilmente de los 
vasos sanguíneos para participar en la defensa de los tejidos y en las superficies corporales. Tiene la capacidad de unirse a antígenos específicos, produciendo su aglutinación y opsonización, también activa el complemento por la vía clásica cuando se han acumulado suficientes moléculas sobre la superficie antigénica provocando su eliminación (Tizard, 2009).

En la década de 1970 se postuló en distintas especies animales, que toda respuesta inmune que cursa con producción de anticuerpos (Ac) del isotipo IgG precipitantes, fijadores de complemento, depuradores de Antígenos, está acompañada por otra población de anticuerpos, también del isotipo IgG con los mismos subtipos que los precipitantes pero que poseen un comportamiento inmunoquímico y biológico diferente, denominados Ac IgG asimétricos (Margni y Binaghi, 1972; Margni, 1989). Estos anticuerpos asimétricos son exclusivamente de la clase IgG y su presencia ha sido demostrada en rata, ratón, oveja, conejo, caballo, vaca, asno y en el ser humano, no habiéndose descripto en porcinos hasta la iniciación de este trabajo de tesis. En nuestro laboratorio hemos determinado la presencia de Ac IgG asimétricos en sueros porcinos y en extractos placentarios, tanto maternos como fetales (Gentile y col., 2004; Garro y col., 2011).

Para Margni (1989) los Ac IgG asimétricos no forman agregados con el antígeno y como consecuencia no activan mecanismos biológicos efectores como lisis por complemento, fagocitosis y depuración antigénica in vivo. No precipitan el antígeno porque en solo una de las dos regiones de unión al antígeno, en los fragmentos Fab, existe un resto hidrocarbonado rico en manosa que crea un impedimento estérico y una marcada disminución de la afinidad al antígeno. Kelemen y col., (1996) proponen que la síntesis de Ac IgG asimétricos se incrementa por la acción de la progesterona, la que ejerce su acción a través de una proteína denomina factor bloqueador inducido por la progesterona (progesterone-induced blocking factor). Margni y Malan 
Borel (1999) proponen, en murinos, que la placenta secreta moléculas o factores que regulan la síntesis de Ac IgG asimétricos, y que la función de éstos sería la protección fetal. Según Gentile y col., (1998) los Ac IgG asimétricos se incrementan en suero y en extractos placentarios durante las gestaciones humanas y murinas. Además, hallaron que en los extractos placentarios existen factores que regulan el balance entre Ac IgG asimétricos/Ac IgG simétricos existentes. Por su parte, Gutiérrez y col., $(2001 ; 2008)$ proponen que el factor placentario regulador que favorece la síntesis de Ac IgG asimétricos sería la interleuquina 6 (IL-6), ya que la producción de Ac IgG asimétricos no es dependiente de la especificidad del antígeno. Canellada y col., (2002) postulan que la modulación de la síntesis de Ac IgG asimétricos estaría dada por los estrógenos, progesterona e IL-6; particularmente demostraron que la IL-6 modularía la glicosilación de las proteínas tanto in vivo como in vitro. En el 2008 (Canellada y col., 2008) publican los mecanismos moleculares a través de los cuales las hormonas esteroideas y la IL-6 aumentan los Ac IgG asimétricos que están involucrados en el mantenimiento de la preñez murina.

Williamson, 2010; Williamson y col. (2011) y Koncurat y col. (2011) detectaron la presencia de IL-6 durante la preñez temprana porcina, a los \pm 32 días de la gestación, solamente en extractos placentarios fetales; mientras que la IL-15 la hallaron en concentraciones altas durante toda la preñez también en extractos placentarios fetales, por lo que postularon que la presencia de estas interleuquinas, que favorecen la síntesis de $\mathrm{IgG}$, serían necesarias para la protección del feto dado que las $\operatorname{IgG}$ y su receptor fueron halladas en cortes histológicos de placentas maternas y de placentas fetales a término (Garro y col., 2007).

En las respuestas inmunes normales, en los sueros de los mamíferos se observa aproximadamente un $15 \%$ de $\mathrm{Ac} \operatorname{IgG}$ asimétricas funcionales sobre el total de $\operatorname{IgG}$ séricas; 
mientras que dichos valores aumentan a un $30 \%$ en sueros humanos y murinos durante la gestación (Malan Borel y col., 1991; Canellada y col., 2002; Apicella y col., 2009).

Dubinsky y col., (2008) confirman que la IL-6 es un factor regulador de la respuesta inmune humoral durante la preñez murina mediante la promoción de síntesis de Ac IgG asimétricos, ya que encuentran que su presencia permite la vascularización de la placenta cuando finaliza la ventana de implantación.

Recientemente, Cortés y col., (2008) y Apicella y col., (2009) han propuesto nuevos roles de los Ac IgG asimétricos; Cortés trabajó con ratas afectadas de artritis y observó que la inoculación de sobrenadantes de extractos placentarios aumenta el porcentaje de Ac $\operatorname{IgG}$ asimétricos y se logra remisión de síntomas. Por su parte, Apicella y col., (2009) detectaron aumento de las moléculas de Ac IgG asimétricos, luego de someter a ratones a una inmunoterapia con ovoalbúmina y el ácido poli $\mathrm{D}$, L, láctico co-glicólico, logrando mejorar la sintomatología de la alergia.

\section{Receptor Fc gama de la IgG}

Las células inmunes, linfocitos $\mathrm{B}$, monocitos, neutrófilos, NK, macrófagos, eosinófilos, basófilos y mastocitos expresan en su superficie moléculas que actúan como receptores para la fracción cristalizable de las inmunoglobulinas (Male y col., 2007; Tizard, 2009), dichos receptores participan en uno de los mecanismos efectores principales a través de los cuales los complejos inmunes IgG ejercen su acción (Xia y col., 2011).

Para que una molécula de IgG se transporte debe unirse, a través de su dominio llamado fracción cristalizable $(\mathrm{Fc})$, a su receptor respectivo. Se han descripto dos clases de receptores $\mathrm{Fc}$ de las 
IgG. Una clase de receptor se encuentra presente en la superficie de las células efectoras para permitir la unión del complejo antígeno-IgG con su receptor y desencadenar la respuesta biológica, ya sea citotoxicidad mediada por células, fagocitosis, liberación de mediadores de la inflamación como regulación de la proliferación y diferenciación de los linfocitos. La otra clase de receptor transfiere las inmunoglobulinas a través de los tejidos epiteliales a sus diferentes lugares de acción, esta clase incluye a los receptores Fc neonatales $(\mathrm{FcRn})$, los cuales transportan inmunoglobulinas (Raghavan y Bjorkman, 1996). Así como la adquisición de la inmunidad humoral a través de la transferencia de IgG de la madre al feto o a la cría presenta diferencias específicas de especie, el mecanismo a través del cual el receptor Fc neonatal protege a la $\operatorname{IgG}$ de la degradación es altamente similar en las especies analizadas (Cervenak y Kacskovics, 2009). Recientemente, mediante un estudio realizado con microscopia electrónica y utilizando anticuerpos unidos a partículas de oro, se identificó un nuevo patrón de distribución de la $\operatorname{IgG}$ en el sincitiotrofoblasto de placentas humanas. La IgG se observó en dos estructuras celulares distintas, en los endosomas unida a su FcRn y en el citoplasma de las células trofoblásticas unido a moléculas C1q del complemento formando complejos inmunes (Li y col., 2014).

El FcRn es una molécula relacionada al Complejo Mayor de Histocompatibilidad (CMH), clase I, que se une al dominio $\mathrm{Fc}$ de la IgG, dependiendo del $\mathrm{pH}$, la unión ocurre a pH ácido y la IgG es liberada a ph 7,4; ya ha sido clonado y caracterizado por Stirling y col., (2005) para su posible uso como transportador de proteínas transepiteliales. Así, el receptor Fc neonatal protege a las IgG del catabolismo y permite mantener constante los niveles de Ac en sueros. Los receptores FcRn se encuentran principalmente en las células endoteliales vasculares y se reciclan, internalizándose para evitar su degradación. También se expresan en otros tejidos y órganos, tales 
como médula ósea y células presentadoras de antígenos profesionales de tejidos de ratones adultos (Akilesh y col., 2007). Además, el receptor Fc neonatal se encuentra en hígado, glándula mamaria e intestino y se sugiere que modula el transporte de IgG a través de los tejidos para alcanzar sus sitios de acción (Ghetie y Ward, 2000). Por su parte Dickinson y col., (1999) demostraron el pasaje de IgG por transcitosis en células epiteliales intestinales humanas a través de un mecanismo de endocitosis mediada por receptor, lo que explicó como las IgG unidas al FcRn atraviesan las células epiteliales y se liberan las IgG en la superficie de la membrana basolateral. Ye y col., (2008) caracterizaron dos variantes del receptor Fe neonatal de las IgG en células epiteliales intestinales porcinas que también se encuentran en diversas localizaciones, tales como riñón y células mononucleares de sangre periférica, sugiriendo que su expresión es regulada por citoquinas proinflamatorias, como el factor de necrosis tumoral $\alpha$ y la IL-1. Recientemente, McConico y col., (2011) lograron la transferencia de células durante el curso de la gestación inyectando células humanas extraídas del cordón umbilical a fetos porcinos de 40-43 días y detectándolas después en la sangre de los fetos y en varios tejidos, tales como riñón, bazo, timo y corazón, lo cual demostraría el pasaje de las IgG.

El conocimiento de que los receptores Fc de las IgG poseen efectos pleiotrópicos sobre las células efectoras y de que están involucrados en el transporte de anticuerpos (Mostov, 1994), la determinación de la vida media de las inmunoglobulinas séricas y de los mecanismos que regulan la producción de anticuerpos, permitió comprender que la heterogeneidad estructural de los receptores $\mathrm{Fc}$ de las $\mathrm{IgG}$ son los responsables de la diversidad funcional que presentan (Kacskovics, 2004). 
Considerando todos los antecedentes expuestos, el estudio de la respuesta inmune humoral mediada por Ac y de sus receptores durante la gestación porcina podría aportar elementos que permitirían comprender los mecanismos que posibilitan la gestación exitosa en porcinos.

\section{HIPÓTESIS}

El sistema inmune humoral participa en la preñez porcina a través de la elaboración de anticuerpos de la clase IgG. Parte de los anticuerpos de la clase IgG que se producen durante la preñez porcina son del tipo IgG asimétricos.

\section{OBJETIVO GENERAL}

Estudiar el rol del sistema inmunitario humoral durante la preñez porcina.

\section{OBJETIVOS ESPECÍFICOS}

1. Determinar la presencia de $\operatorname{IgG}$ en placentas provenientes de distintos períodos gestacionales.

2. Identificar la existencia de IgG asimétricas en muestras de suero y de placenta de diferentes períodos gestacionales.

3. Identificar la presencia de receptores $\mathrm{Fc}$ en células placentarias. 


\section{MATERIALES Y MÉTODOS}

\section{$\underline{\text { Animales }}$}

Se obtuvieron 45 tractos reproductivos de cerdas mestizas provenientes de la zona de General Pico, La Pampa, Argentina ( $35^{\circ} 62^{\prime}$ y $63^{\circ} 45^{\prime}$ de latitud y longitud), durante la faena en un frigorífico regional luego del sacrificio mediante un método controlado llamado Sistema de Aturdimiento Eléctrico, el que consta de un cajón de noqueo o insensibilización eléctrica.

De los 45 tractos reproductivos procesados 17 correspondieron a preñeces de \pm 30 días, 9 a preñeces de $\pm 65 / 70$ días, 6 a preñeces de \pm 95 a 114 días y 13 a cerdas vacías.

Todas las cerdas procesadas fueron consideradas libres de enfermedad mediante el correspondiente examen post mortem.

Los tractos reproductivos fueron recolectados inmediatamente luego de la muerte del animal, se lavaron con solución salina de Hank's que contenía $10.000 \mathrm{U} / \mathrm{ml}$ de penicilina, $10 \mathrm{mg} / \mathrm{ml}$ de estreptomicina y $2,5 \mathrm{ug} / \mathrm{ml}$ de fungizona, y se mantuvieron a $4^{\circ} \mathrm{C}$ hasta su procesamiento en el laboratorio.

Además, antes de su sacrificio, a cada hembra se le extrajeron $100 \mathrm{ml}$ de sangre mediante flevopunción, de las venas cava craneal, medial de la oreja o yugular, según el caso.

\section{Obtención de suero}

Una vez obtenida la sangre, los tubos de ensayo conteniendo las muestras se sumergieron en un baño termostatizado a $37^{\circ} \mathrm{C}$, durante 30 a 60 minutos, a los efectos de producir la retracción del coágulo y la exudación del suero. Las muestras de suero así obtenidas se centrifugaron a 1800 
rpm durante 10 minutos, para su clarificación. Finalmente, se fraccionaron en alícuotas y se conservaron a $-20^{\circ} \mathrm{C}$ hasta su uso.

\section{Procesamiento de los tractos reproductivos}

Los tractos reproductivos se colocaron sobre una mesada y se lavaron con solución salina de Hank's. Se palparon para ubicar los embriones y fetos y se pesaron. Posteriormente, los cuernos uterinos fueron abiertos en forma longitudinal, con una incisión por el borde antimesometrial, observando el sitio de implantación de cada embrión o feto. Se recogieron muestras de miometrio, endometrio y placenta fetal para estudios histológicos y para la obtención de extractos placentarios porcinos: homogenatos de placenta materna, homogenatos de placenta fetal y homogenatos de útero no gestante. Debido al tipo de placenta, no invasiva, resultó fácil separar el tejido placentario materno del fetal, ejerciendo leve tracción sobre los mismos.

\section{Determinación del período de gestación}

Se estimó el período de preñez de las cerdas de acuerdo a la medición de la longitud céfalocaudal de los embriones y/o fetos obtenidos de cada cerda gestante (Marrable, 1971).

\section{Procesamiento de la placenta y del útero para estudios histológicos}

Las muestras de tejido placentario y de útero fueron fijadas en formol neutro al $10 \%$ y procesadas mediante técnicas histológicas convencionales hasta su inclusión en parafina. Se realizaron cortes de $5 \mu \mathrm{m}$ de espesor, los que se montaron de a tres o cuatro por portaobjetos. Algunos se colorearon con hematoxilina-eosina y se observaron en un microscopio Axiophot (Zeiss, 
Göttingen, Alemania). La captura de imágenes se realizó con una cámara Canon, PowerShot G6 de 7,1 megapixels (Canon, Tokio, Japón).

Obtención de homogenatos de placenta materna (HoPM), de placenta fetal (HoPF) y de útero no gestante $(\mathrm{HoU})$

Para la obtención de los homogenatos placentarios y de útero no gestante se utilizó un molinillo eléctrico (Moulinex, Argentina). Se separó cuidadosamente la porción placentaria materna de la fetal. Se homogeneizó una parte de tejido placentario con tres partes de solución fisiológica. Para eliminar los restos de tejidos, se centrifugó 2 veces a $1800 \mathrm{rpm}$, durante 10 minutos cada vez. El sobrenadante se dividió en alícuotas y se almacenó a $-20^{\circ} \mathrm{C}$ hasta su uso. Las muestras de endometrio de úteros no gestantes se procesaron de la misma manera.

\section{Detección de IgG y del receptor Fc gama de la IgG mediante una técnica de} inmunohistoquímica (IHQ)

Se determinó la presencia de $\operatorname{IgG}$ en cortes histológicos de tejido placentario de los períodos seleccionados y en cortes de útero no gestante mediante tres anticuerpos diferentes anti $\operatorname{IgG}$ porcino. Uno elaborado en cabra, biotilinado (sc 2465), dilución 1:1000 (Laboratorio Santa Cruz Biotechnology Inc, USA), otro elaborado en cabra conjugado con peroxidasa (sc 2463), dilución 1:5000 (Laboratorio Santa Cruz Biotechnology Inc, USA) y el tercer anticuerpo anti IgG porcino utilizado fue elaborado en cabra conjugado con peroxidasa, dilución 1:2000 (Bethyl Laboratories Inc, Montgomery, USA). Para el primer Ac utilizado se realizó una técnica de inmunoperoxidasa indirecta, actuando como marcador enzimático la peroxidasa y como revelador la 
diaminobenzidina (DAB). Se desparafinaron los cortes de tejido placentario de los períodos correspondientes mediante el siguiente protocolo: 3 pasajes en xilol $100^{\circ}$ de 10 minutos cada uno, 2 pasajes en alcohol $100^{\circ}$ de cinco minutos cada uno, 2 pasajes en alcohol $96^{\circ}$ de cinco minutos cada uno, 2 pasajes en agua destilada de diez minutos cada uno y 2 pasajes en solución salina tamponada (PBS) de diez minutos cada uno. Se agregó peróxido de hidrógeno al 3\% para bloquear la peroxidasa endógena durante $20^{\prime}$, posteriormente, se realizó dos lavados con PBS durante $5^{\prime}$ cada uno. Se agregó albumina sérica bovina al 3\% durante $15^{\prime}$ para bloquear reacciones inespecíficas. Los cortes se escurrieron y se cubrieron con el anticuerpo anti IgG, cada portaobjeto se cubrió sin presionar con parafilm "M" (Laboratory film-American National ${ }^{\mathrm{TM}}$, USA) con el fin de homogeneizar el contacto del tejido con el anticuerpo y se incubó en cámara húmeda durante toda la noche a $4^{\circ} \mathrm{C}$. Se retiró la cámara húmeda de la heladera, se lavó con PBS dos veces por 5'cada lavado. Posteriormente, se incubó con el complejo Streptavidina-Peroxidasa (DAKO, USA) durante $20^{\prime}$ a temperatura ambiente. Se lavó con PBS dos veces de 5 'cada uno y se reveló la marcación realizada con diaminobencidina (DAB, USA) durante 15', controlando visualmente la reacción hasta la aparición de color pardo; para detener la misma se sumergieron los preparados histológicos en baño de agua corriente y luego se lavaron con agua destilada. Posteriormente, se contrastó con hematoxilina (Mayer Sigma - Aldrich Chemie, Steinheim, Alemania) durante 4", se lavó con agua corriente tibia, durante segundos y luego se colocaron diez minutos en agua corriente tibia. Posteriormente se llevó a cabo la deshidratación, el montaje de los portaobjetos y se observó en un microscopio Axiophot (Zeiss, Alemania); la captura de imágenes se realizó con una cámara Canon, Power Shot G6, de 7,1 megapixeles (Canon, Tokio, Japón) conectada al mismo. 
Con los otros dos Ac anti IgG se llevó a cabo la misma técnica de IHQ pero sin la utilización del complejo Streptavidina-Peroxidasa, debido a que los anticuerpos utilizados no eran biotinilados.

Para la observación en los tejidos del receptor para el Fe gama de la IgG se llevó a cabo la técnica de IHQ directa, sin la utilización del complejo Streptavidina-Peroxidasa, debido a que el anticuerpo no estaba biotinilado. Se utilizó un anticuerpo anti Fc gama marcado con peroxidasaA-100-104P, dilución 1:1000 (Bethyl Laboratories Inc, Montgomery, USA). Los preparados se observaron en un microscopio Axiophot (Zeiss, Göttingen, Alemania).

Los resultados de las técnicas de marcación para determinación de IgG y del receptor Fc gama se expresaron en forma semicuantitativa, con la siguiente escala elegida en función de la intensidad de la coloración detectada:

(-) negativo

$(+)$ baja positividad

$(++)$ positividad intermedia

$(+++)$ alta positividad

\section{Determinación de IgG simétricas e IgG asimétricas}

La detección de IgG simétricas y asimétricas se llevó a cabo mediante cromatografía de afinidad - Elisa de captura en las muestras de suero y de homogenatos placentarios maternos y fetales y de útero no gestante. Considerando que dentro de las propiedades de la concanavalina A (Con-A) se encuentra su alta afinidad por oligosacáridos tipo "high manose" presentes en el Fab de las moléculas de IgG asimétricas, se utilizó como adsorbente Con-A- sepharosa. Para ello se pusieron en contacto volúmenes iguales de las muestras y de Con A-sepharosa en buffer Tris 
durante 2 horas a $4^{\circ} \mathrm{C}$ en agitación. Paralelamente, a fin de poder determinar el nivel de IgG total y tener las muestras en las mismas condiciones, las muestras se incubaron en la misma proporción (v/v) con el tampón de fijación (Buffer Tris-ClH 0,025 M; ClNa 0,2 M; Cl2Ca 0,003 M; $\mathrm{Cl}_{2} \mathrm{Mg}$ 0,003 M y Cl2Mn 0,003 M, pH 7,2) (Canellada A. y col., 2002). Posteriormente las muestras se centrifugaron para determinar los niveles de $\operatorname{IgG}$ presentes en los sobrenadantes utilizando la técnica de ELISA.

Se utilizaron microplacas de alto pegado y 96 pocillos (Nunc, USA). Para la sensibilización de las placas a utilizar en el ELISA, se sembraron $50 \mu 1$ por pocillo de un anticuerpo anti- Fc de IgG porcina elaborado en cabra (Bethyl, USA) 1:500 en solución tamponada $\mathrm{HCO}_{3} \mathrm{Na} / \mathrm{CO}_{3} \mathrm{Na} 0,1 \mathrm{M}$ pH $8,5(0,1 \mu \mathrm{g} /$ pocillo $)$, y se incubaron durante 2,5 horas a $37^{\circ} \mathrm{C}$ en cámara húmeda. Luego de lavados con PBS $\left(3,2 \mathrm{mM} \mathrm{Na}_{2} \mathrm{HPO}_{4}, 0,5 \mathrm{mM} \mathrm{KH} \mathrm{K}_{2} \mathrm{PO} 4,1,3 \mathrm{mM} \mathrm{KCl}, 135 \mathrm{mM} \mathrm{NaCl}\right)$ se realizó el bloqueo de los sitios libres con $200 \mu 1$ por pocillo con una solución de leche descremada (Molico ${ }^{\circledR}$ ) al $10 \%$, durante toda la noche y a $4^{\circ} \mathrm{C}$. Luego de lavar las placas nuevamente, se colocaron $50 \mu 1$ por pocillo de diferentes diluciones de las muestras del sobrenadante de la adsorción con Con-A sepharosa (IgG simétricas) y de las muestras sin adsorber (IgG totales) respectivamente. Se incubó en cámara húmeda durante una hora y media, se lavaron las placas con PBST (3,2 mM Na $2 \mathrm{HPO}_{4}, 0,5 \mathrm{mM} \mathrm{KH} 2 \mathrm{PO} 4,1,3 \mathrm{mM} \mathrm{KCl}, 135 \mathrm{mM} \mathrm{NaCl}, 0,05 \%$ Tween 20, $\mathrm{pH} 7,4)$. A posteriori, se agregaron $50 \mu 1$ por pocillo del conjugado anti-Fc gama marcado con peroxidasa, (Bethyl, USA) y se incubaron en estufa durante 45', la reacción se evidenció por el agregado de o-fenilen-diamina (OPD, Sigma, USA) ( $1 \mathrm{mg} / \mathrm{ml}$ en buffer citrato-fosfato $+\mathrm{H}_{2} \mathrm{O}_{2}$ al 3\%). Las densidades ópticas (DO) se determinaron espectrofotométricamente (BioTeK ${ }^{\circledR}$ Instruments, Inc. USA) a $490 \mathrm{~nm}$, lo que permitió calcular el porcentaje de moléculas 
asimétricas, utilizando la siguiente fórmula: \% IgG unida a Con A= 100-( IgG no fijada a la Con A/ IgG total) x 100 (Zenclusen y col., 2001; Apicella y col., 2009; Cortes y col., 2008).

\section{Cuantificación de proteínas}

Se determinó la concentración de proteínas totales en las diferentes muestras séricas, en los extractos placentarios maternos y fetales y en úteros no gestantes. Dada la baja concentración de proteínas halladas en los homogenatos con respecto al suero, se utilizaron diferentes técnicas.

\section{Determinación de proteínas totales y albúmina en HoPM, HoPF y HoU}

Para la cuantificación de proteínas totales en homogenatos maternos y fetales y en útero no gestante se utilizó un método colorimétrico cuantitativo humano (kit comercial Proti-U, Wiener Lab, Rosario, Argentina). Se llevaron a temperatura ambiente los reactivos y las muestras antes de iniciar el ensayo. Las muestras fueron centrifugadas durante 5 minutos a $3000 \mathrm{rpm}$. Se utilizaron placas de 96 pocillos fondo plano, rotulando en las mismas los pocillos para el blanco, estándar y muestra. De cada muestra a analizar se colocaron en un pocillo, el estándar $5 \mu \mathrm{l}$ (solución de albúmina $100 \mathrm{mg} / \mathrm{dl}$ ) y $250 \mu \mathrm{l}$ del reactivo A (solución estabilizada de rojo pirogalol $0,1 \mathrm{mmol} / 1$, molibdato de sodio $0,1 \mathrm{mmol} / 1$ en buffer succinato $50 \mathrm{mmol} / 1, \mathrm{pH} 2,5)$. Se mezcló y se incubó la placa durante 10 minutos a $37^{\circ} \mathrm{C}$. Las proteínas presentes en los extractos reaccionaron en medio ácido con el complejo rojo de pirogalol-molibdato, originando un complejo que se leyó en espectrofotómetro (Metrolab 2300 Plus Wimer, Argentina) entre 580 $630 \mathrm{~nm}$. 


\section{Determinación de proteínas totales y albúmina en sueros}

Se utilizó un método colorimétrico para la determinación de proteínas totales y albúmina en sueros con kits comerciales humanos Proti 2 (Wiener Lab, Rosario, Argentina). Los enlaces peptídicos de las proteínas reaccionan con el ión cúprico, en medio alcalino, para dar un complejo de color violeta con máximo de absorción a $540 \mathrm{~nm}$, siendo la intensidad proporcional a la concentración de proteínas totales en la muestra. Se utilizaron tres tubos, marcados B (blanco), S (estándar) (que es una solución mixta de proteínas) y D (muestras). En el tubo B se colocaron 50 $\mu 1$ de agua destilada y $3,5 \mathrm{ml}$ de reactivo EDTA/Cu. En el tubo $\mathrm{S}$ se agregaron $50 \mu 1$ de suero patrón y 3,5 $\mathrm{ml}$ de reactivo EDTA/Cu. En los tubos D, se colocaron $50 \mu \mathrm{l}$ por cada una de las muestras a analizar y $3,5 \mathrm{ml}$ de reactivo EDTA/Cu. Se mezclaron con varilla y se incubaron 15 minutos a $37^{\circ} \mathrm{C}$. Se leyeron las DO en un espectrofotómetro (Metrolab 2300 Plus, Wimer Argentina) a $540 \mathrm{~nm}$, llevando a cero con el blanco de reactivo.

De la misma manera se determinó la concentración de albúmina, que reacciona específicamente con la forma aniónica de la 3, 3', $5,5^{\prime}$ - tetrabromo- cresolsulfon -ftaleína (BCF), en presencia de un exceso de colorante, en medio tamponado a $\mathrm{pH} 3,8$. El aumento de la absorbancia a $625 \mathrm{~nm}$ respecto del blanco, es proporcional a la cantidad de albúmina presente en la muestra. Se rotularon los tubos en blanco, estándar y muestra. Se colocó el estándar, $10 \mu 1$ de suero patrón con título conocido de albúmina en estado nativo. Posteriormente se procedió a colocar las muestras en razón de $10 \mu 1$ por tubo. En último lugar, se colocó el reactivo BCF 3,5 ml en cada tubo. Se mezcló con varilla, manteniendo los tubos entre 15 y $28^{\circ} \mathrm{C}$ durante 10 minutos. La lectura se realizó en un espectrofotómetro (Metrolab 2300 Plus, Wimer Argentina) a $540 \mathrm{~nm}$, llevando a cero con el blanco del reactivo. La coloración de la reacción fue estable durante 12 
horas, por lo que la absorbancia se leyó dentro de ese lapso. Se calcularon los resultados de la siguiente manera:

Proteínas totales $(\mathrm{g} / \mathrm{dl})=\mathrm{DO} \times \mathrm{f} \quad$ Siendo $\mathrm{f}=\operatorname{PrT}(\mathrm{g} / \mathrm{dl}) /$ Standard
Albúmina $(\mathrm{g} / \mathrm{dl})=\mathrm{DO} \times \mathrm{f}$
Siendo $\mathrm{f}=\mathrm{Alb}(\mathrm{g} / \mathrm{dl}) /$ Standard

\section{Determinación de inmunoglobulina G mediante un método inmunoturbidimétrico}

Para la determinación de la $\operatorname{IgG}$ en sueros y homogenatos maternos, fetales y de útero no gestante, se utilizó un método inmunoturbidimétrico con kits comerciales humanos Turbitest AA IgG (Wiener Lab. Rosario, Argentina). La IgG reacciona con el anticuerpo específico formando inmunocomplejos insolubles, que se manifiestan como una turbidez proporcional a la concentración de $\operatorname{IgG}$ en las muestras. Se midió en un espectrofotómetro (Metrolab 2300 Plus Wimer, Argentina).

Mediante esta técnica se cuantificó la presencia y concentración de $\operatorname{IgG}$ en sueros, homogenatos maternos, fetales y de útero no gestante. En primer lugar se realizó una curva de calibración empleando tubos de Kahn, con diluciones (1:10), (1:20), (1:40), (1:80) y (1:160) del calibrador de proteínas en solución fisiológica (Suero inactivo con conservadores Turbist AA de Wiener Lab. Rosario, Argentina). Se empleó como punto cero solución fisiológica. Se agregaron $40 \mu 1$ del calibrador de proteína diluida. A cada tubo se adicionaron $900 \mu 1$ del reactivo A provisto por el kit (solución fisiológica tamponada a pH 7,5). Se homogeneizaron las muestras y se leyó la absorbancia en un espectrofotómetro (Metrolab 2300 Plus Wimer Argentina) a $340 \mathrm{~nm}\left(\mathrm{DO}_{1}\right)$. Se agregaron $160 \mu 1$ del reactivo B (el anticuerpo específico anti-IgG), se mezclaron e incubaron durante 30 minutos a temperatura ambiente y se leyó a $340 \mathrm{~nm}\left(\mathrm{DO}_{2}\right)$. Se calculó la diferencia de 
absorbancia para cada dilución del calibrador y para el punto cero, restando la $\mathrm{DO}_{2}$ de la $\mathrm{DO}_{1}$. Se representaron en papel milimetrado las diferencias de absorbancia en función de la concentración de proteínas en $\mathrm{mg} / \mathrm{dl}$. Posteriormente se diluyeron las muestras 1:10 en solución fisiológica (40 $\mu 1)$. Se colocaron $900 \mu 1$ del Reactivo A. Se homogeneizaron y se leyeron a $340 \mathrm{~nm}\left(\mathrm{DO}_{1}\right)$, llevando el aparato a cero con agua destilada. Se agregó el Reactivo B en un volumen de $160 \mu$ l. Se mezclaron y se incubaron durante 30 minutos a temperatura ambiente. Nuevamente, se leyó la absorbancia a $340 \mathrm{~nm}\left(\mathrm{DO}_{2}\right)$, llevando el aparato a cero con agua destilada. Se calculó la diferencia de absorbancia restando la $\mathrm{DO}_{2}$ de la $\mathrm{DO}_{1}$ en cada muestra analizada. Se interpolaron los valores de las diferencias a la curva de calibración y se determinó la concentración en mg/dl de cada muestra analizada.

\section{Determinación de IgG mediante inmunodifusión radial (IDR)}

Se determinó la presencia de IgG porcina en sueros de hembras preñadas en distintos períodos gestacionales y de hembras no gestantes, mediante placas de agarosa (Diffu-Plate, Biocientífica S.A. Capital Federal, Argentina) conteniendo antisueros específicos para IgG humana.

Es una técnica cuantitativa basada en una inmunoprecipitación en agarosa entre un antígeno a cuantificar y su anticuerpo homólogo. Las muestras previamente se centrifugaron a $1400 \mathrm{rpm}$ durante 10 minutos y luego se sembraron $5 \mu$ en los pocillos cavados en el gel. Se incubaron en posición invertida en cámara húmeda a $23^{\circ} \mathrm{C}$ durante 48 horas. El punto final de la difusión se consideró cuando aparecieron anillos de bordes netos. La lectura se realizó midiendo los diámetros de los halos de precipitación. Se interpolaron los datos en la tabla de valores que acompaña al kit y se determinaron las concentraciones de cada muestra en mg/dl. 


\section{Análisis estadístico}

Se realizó un análisis estadístico de las variaciones de las concentraciones de IgG simétricas e IgG asimétricas, de proteínas totales, albúmina, IgG dosada mediante inmunodifusión radial e IgG dosada mediante inmunoturbidimetría en muestras de suero y homogenatos maternos y fetales. Para ello, se utilizó el ANOVA y una prueba de comparaciones múltiples mediante el test de Tukey $(\mathrm{p}<0,05)$. Se realizó una estadística descriptiva de posición y dispersión. Se calcularon los valores medios y las desviaciones de las distintas variables, con sus correspondientes gráficos de puntos, mediante Modelos Lineales Generales, considerando cada una de las muestras y comparando diferentes factores, tal como el período de gestación. Se utilizó el soft estadístico InfoStat versión 2011e y, en todos los casos, el nivel de significación que se consideró fue del 5\% (Di Rienzo et al., 2011). 


\section{RESULTADOS}

\section{Estructura de la placenta y del útero: análisis microscópico}

Se realizaron observaciones microscópicas de la estructura placentaria en distintos períodos gestacionales y de útero no gestante, correspondiendo su aspecto con el descripto como normal para el período del ciclo estral correspondiente o para la etapa de la gestación en que se recolectó la muestra.

La figura 6 corresponde a un útero no gestante coloreado con hematoxilina eosina. La mucosa presenta proyecciones o pliegues que incluyen el epitelio y el mesémquima de tejido conectivo. El epitelio es cilíndrico pseudoestratificado con cilias y apoya sobre el tejido conectivo laxo. Por debajo de este se observa un conectivo profundo, también de tejido conectivo laxo, que contiene los adenómeros de las glándulas uterinas y una gran vascularización.

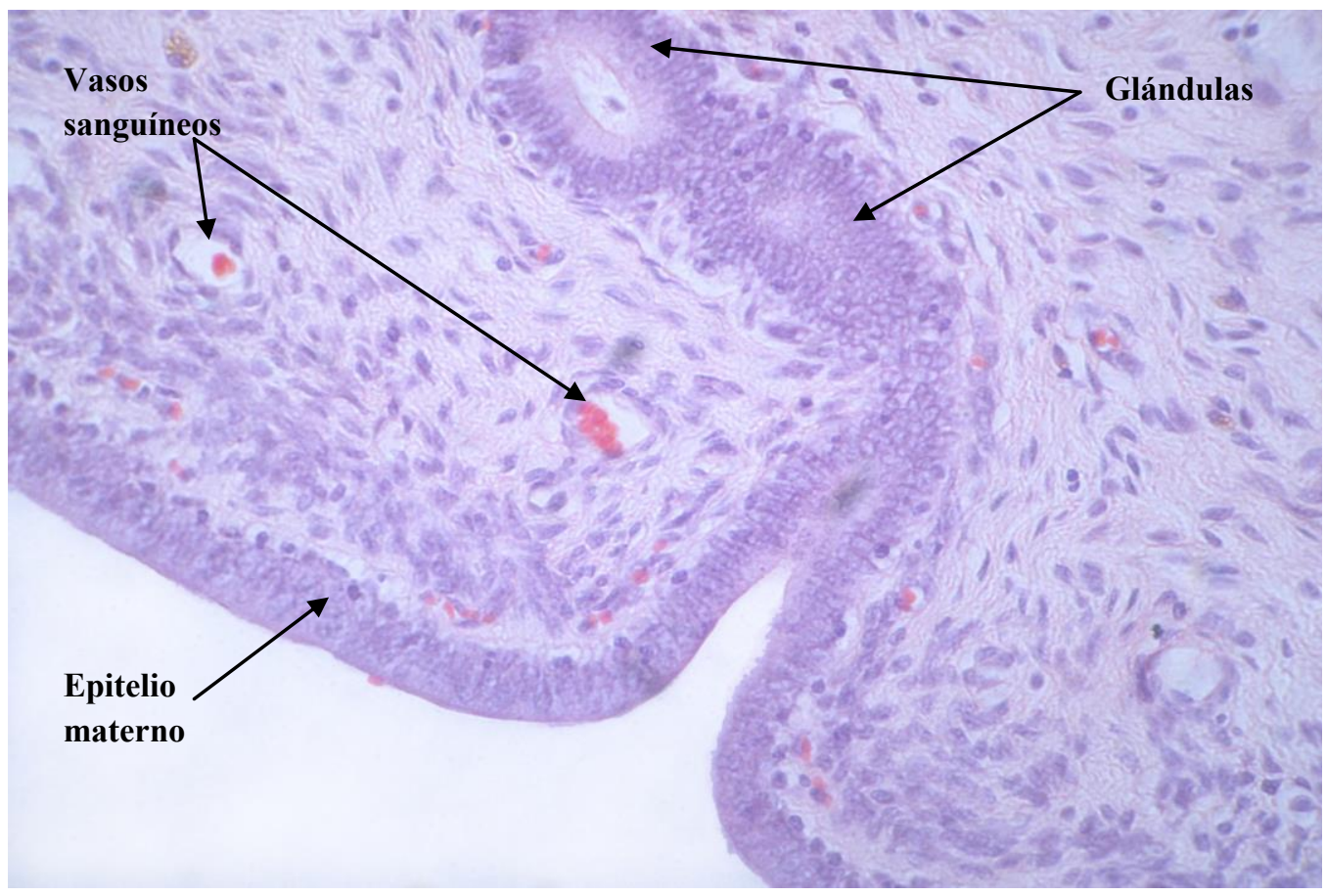

Figura 6: Corte de útero de hembra no gestante. Se observa glándulas uterinas, vasos sanguíneos y células del tejido conectivo. HE 40x 


\section{Expresión de IgG en diferentes períodos gestacionales y en útero no gestante}

Se analizó la expresión de IgG en cortes histológicos de útero no gestante y de placentas fetales y maternas en diferentes períodos gestacionales mediante inmunohistoquímica, Tabla 1.

Tabla 1: Expresión de $\operatorname{IgG}$ en útero no gestante y en placentas de diferentes períodos gestacionales.

\begin{tabular}{|c|c|c|c|c|c|}
\hline \multirow{2}{*}{$\begin{array}{c}\text { Tracto } \\
\text { Reproductivo }\end{array}$} & \multicolumn{3}{|c|}{ Epitelio } & \multicolumn{2}{c|}{ Glándulas Uterinas } \\
\cline { 2 - 6 } \cline { 4 - 5 } $\begin{array}{c}\text { Útero } \\
\text { no gestante }\end{array}$ & Uterino & Vell. Fet. & Vell. iviat. & Células & Lumen \\
\hline 30 días & & & & - & - \\
\hline $65-70$ días & & $++/+++$ & ++ & +++ & ++ \\
\hline $95-114$ días & & $++/+++$ & $++/+++$ & ++ & +++ \\
\hline
\end{tabular}

Vell: Vellosidad; Fet: Fetal; Mat: Materno; +, ++, +++: Diferentes grados de positividad; -Negativo.

En los cortes histológicos de útero no gestante, no se observó en epitelio uterino ni en las glándulas uterinas inmunomarcaje positivo a IgG.

En la figura 7 se observa una interfase de 30 días de gestación con inmunomarcaje positivo (+++) a IgG, sobre la membrana apical de las células epiteliales que conforman el lumen de la interfase feto materna; algunas de las células trofoblásticas presentan marcaje positivo en el citoplasma. Además, se observa marcaje positivo a IgG en las membranas basales y apicales de células epiteliales pertenecientes a las vellosidades maternas.

En la figura 8 se observa marcaje positivo $(+++)$ a IgG en vellosidades trofoblásticas. 


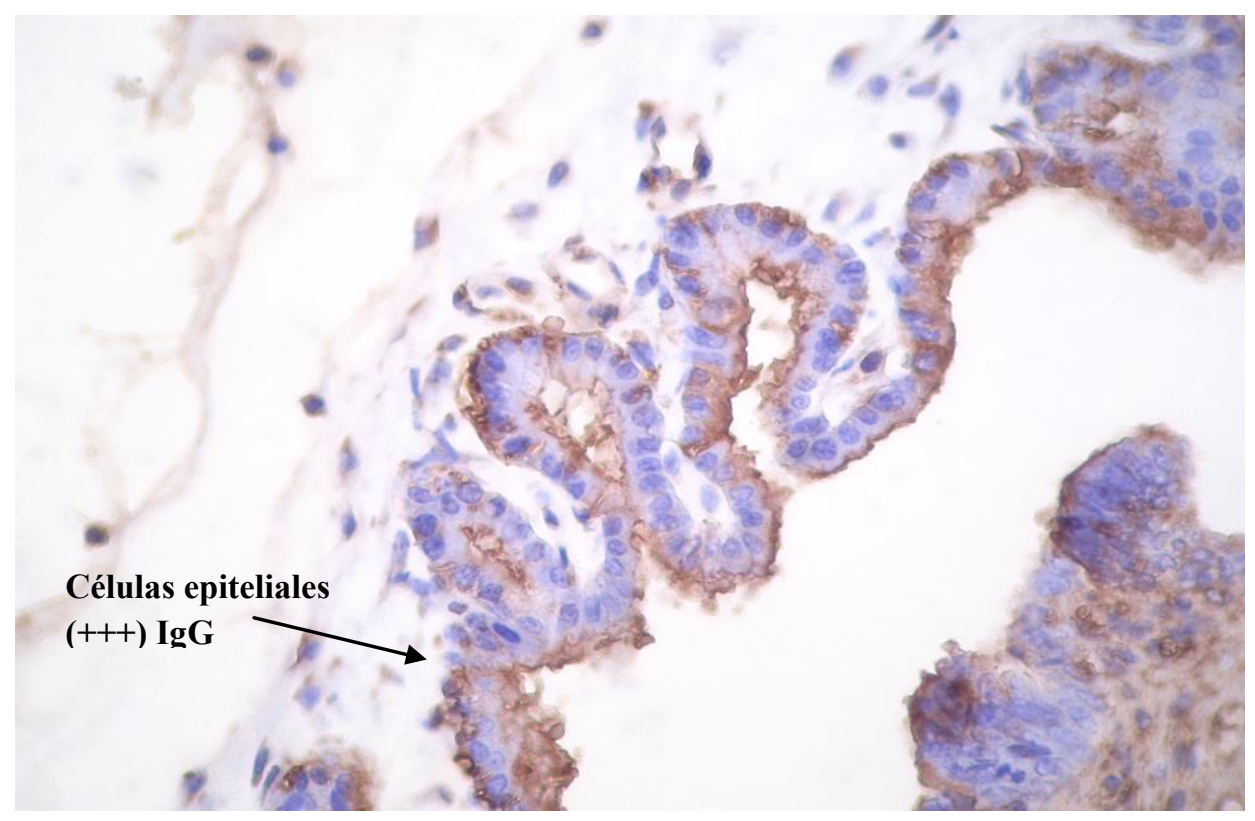

Figura 7: Placenta de 30 días de gestación. Se observa inmunomarcaje positivo a IgG en las células del trofoblasto y en el epitelio materno. IHQ 40x

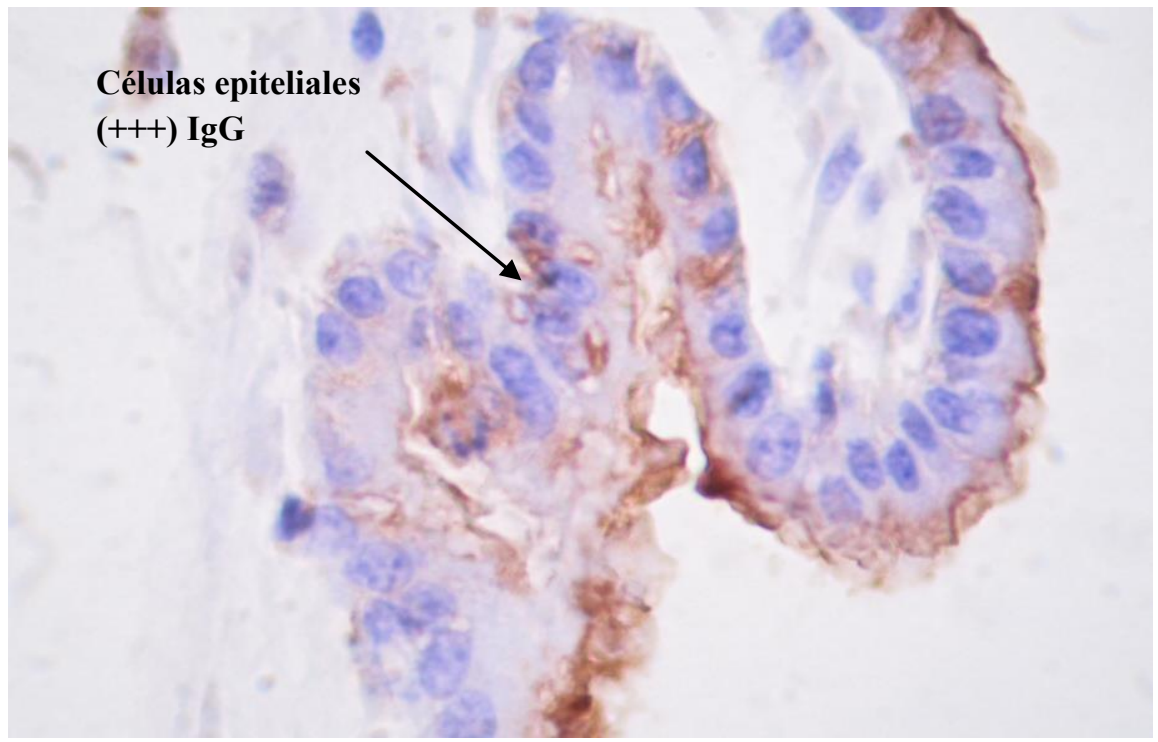

Figura 8: Placenta de 30 días de gestación. Inmunomarcaje positivo $(+++)$ a $\mathrm{IgG}$ en vellosidades trofoblásticas. IHQ 100x 
En la figura 9, fotografía correspondiente a una placenta de 30 días de gestación se observa un inmunomarcaje positivo $(+++)$ a IgG en glándulas, en la región luminal y en la membrana basal de las células que las componen.

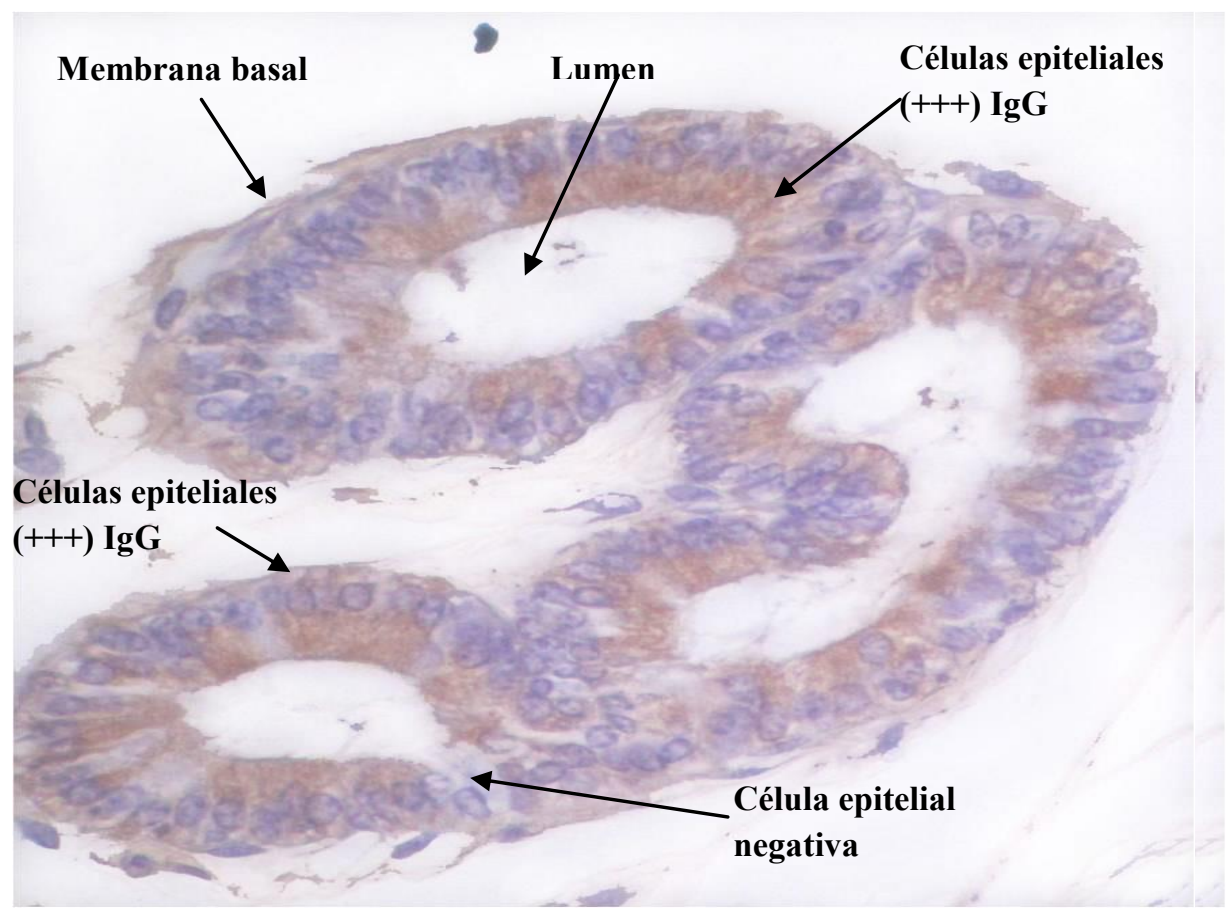

Figura 9: Placenta de 30 días de gestación. Inmunomarcaje positivo a IgG en células epiteliales de glándulas maternas. IHQ 40x

En placentas de 65-70 días de gestación, se observó inmunoreacción positiva (++/+++) a IgG en la membrana basal de las células epiteliales de las vellosidades del trofoblasto, así como también en el citoplasma y en la membrana apical de dichas células. En la membrana basal de las células que constituyen las glándulas de la placenta materna se observó inmunoreacción positiva $(++)$ mientras que en la luz de las mismas se pudo observar una inmunoreacción más marcada $(+++)$. En la figura 10 se observa una placenta de 65 días de gestación con inmunomarcación positiva (++/+++) a IgG 
en la membrana apical de las vellosidades del trofoblasto hacia el lumen interfásico. En la figura 11 se aprecia inmunomarcaje $(++/+++)$ a IgG en la interfase feto materna.

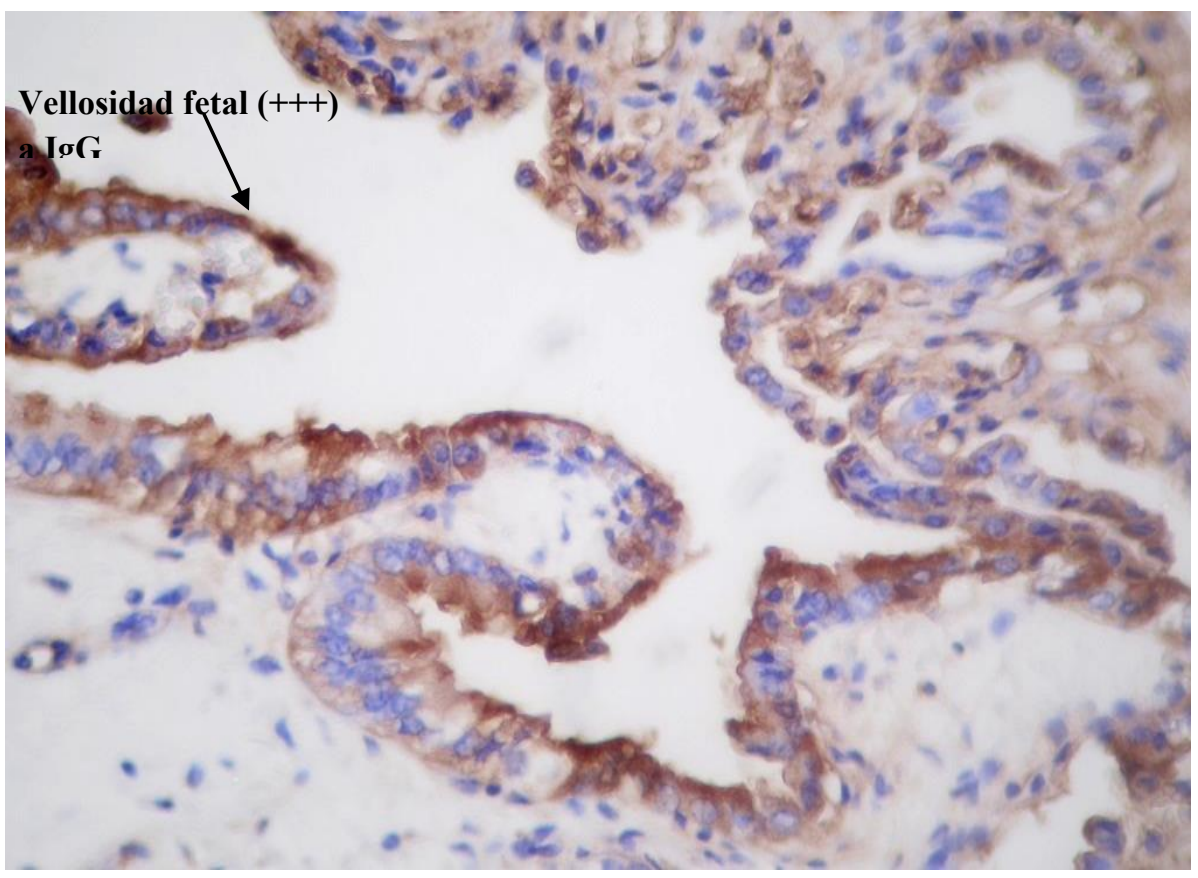

Figura 10: Placenta fetal de 65 días de gestación. Inmunomarcaje positivo a IgG en vellosidades trofoblásticas. IHQ 40x

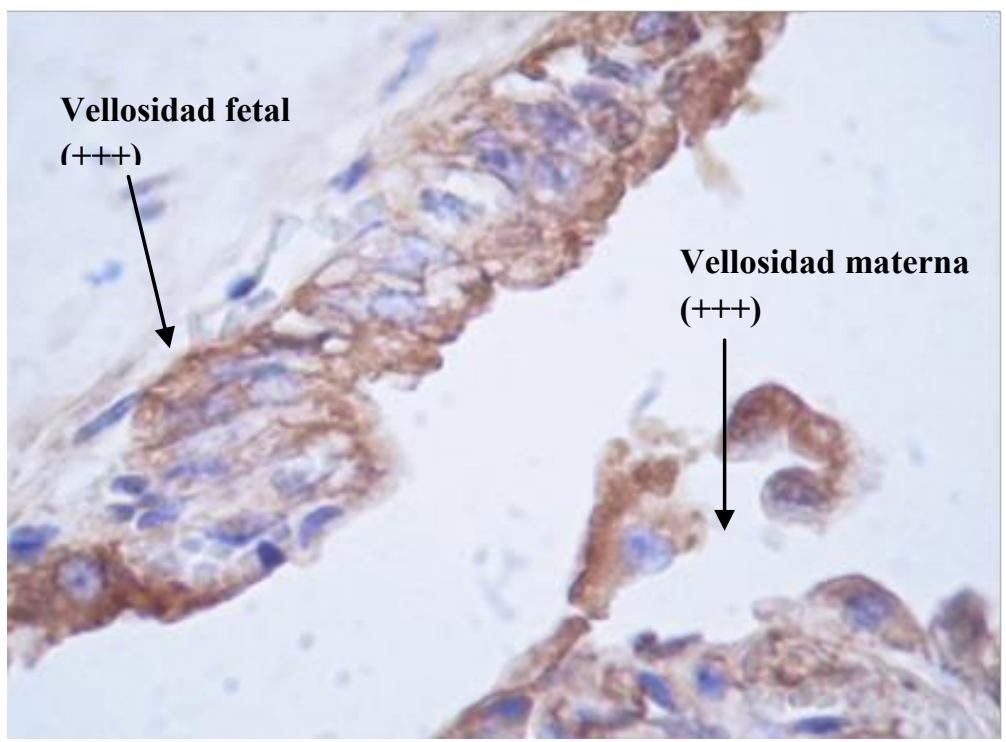

Figura 11: Interfase feto materna de 65 días de gestación. Inmunomarcaje positivo a IgG. IHQ 100x 
Podemos observar en la figura 12 una placenta fetal a término, donde se aprecia un inmunomarcaje positivo (+++) a IgG en las células epiteliales que conforman el trofoblasto.

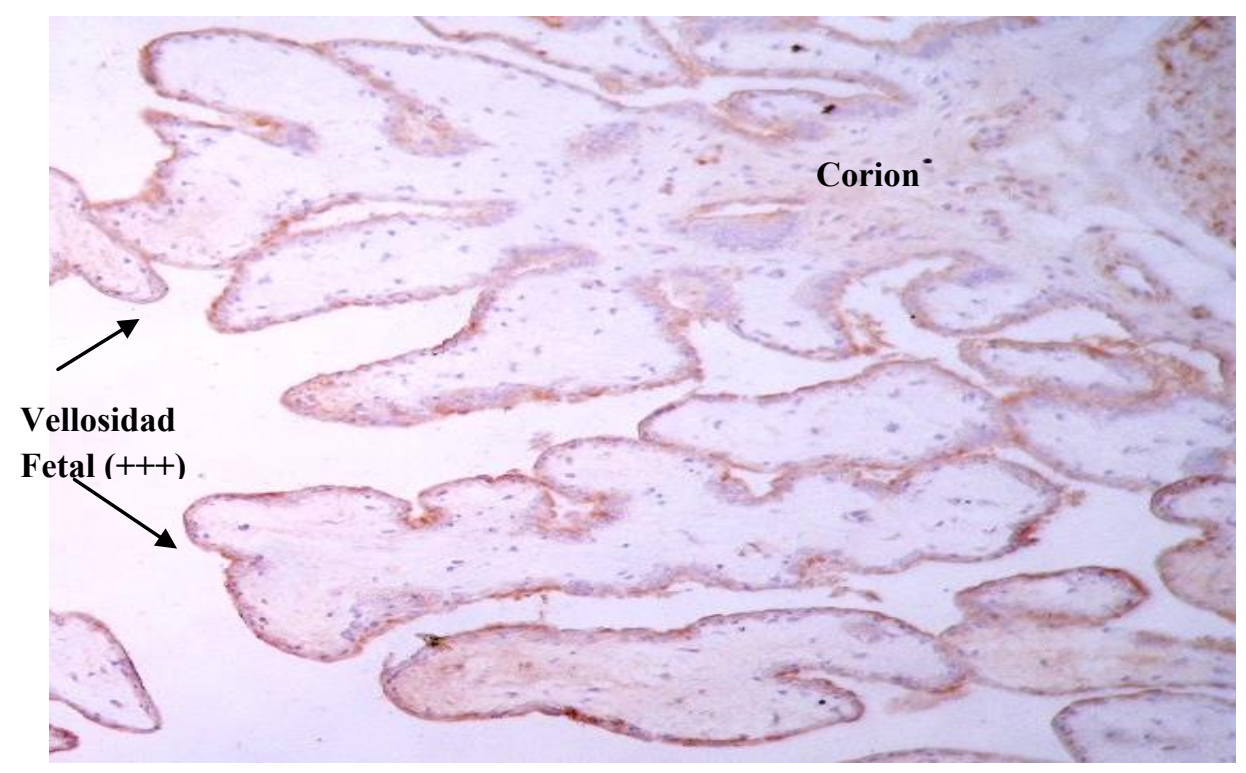

Figura 12: Placenta fetal a término. Inmunomarcaje positivo a IgG en vellosidades trofoblásticas. IHQ 10x

En la figura 13, a mayor aumento, se aprecia la inmunomarcación a $\operatorname{IgG}(+++)$ en vellosidades fetales a término.

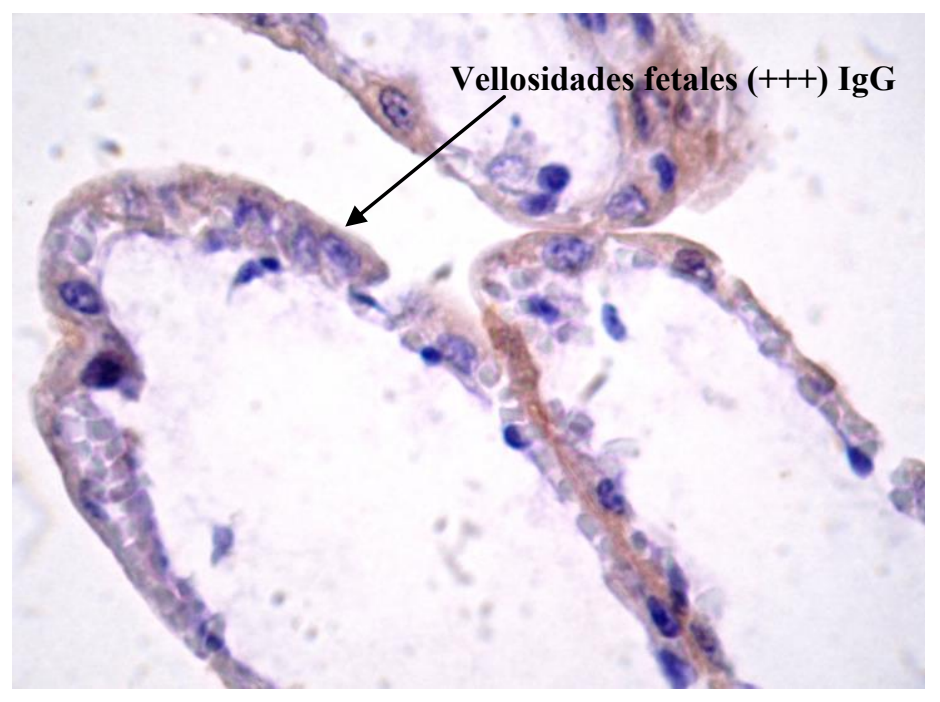

Figura 13: Placenta fetal a término. Inmunomarcaje positivo a IgG en vellosidades trofoblásticas. IHQ 100x 


\section{Expresión del receptor Fc gama de IgG}

Se analizó la expresión del receptor Fc gama de IgG mediante inmunohistoquímica en útero vacío y en muestras placentarias fetales y maternas de los períodos gestacionales seleccionados (Tabla 2).

Tabla 2: Expresión del Receptor Fc gama de la IgG en útero no gestante y placentas de diferentes períodos gestacionales.

\begin{tabular}{|l|c|c|c|c|c|}
\hline \multirow{2}{*}{\multicolumn{1}{|c|}{ Tracto }} & \multicolumn{3}{c|}{ Epitelio } & \multicolumn{2}{c|}{ Glándulas Uterinas } \\
\cline { 2 - 6 } & Uterino & Vell. Fet & Vell Mat. & Células & Lumen \\
\hline Útero no gestante & - & & & - & - \\
\hline 30 días & & +++ & +++ & ++ & ++ \\
\hline 65-70 días & & +++ & +++ & ++ & ++ \\
\hline 95-114 días & & +++ & ++ & - & - \\
\hline
\end{tabular}

Vell: Vellosidad; Fet: Fetal; Mat: Materno; +, ++, +++: Diferentes grados de positividad; -Negativo.

En úteros vacíos, el epitelio luminal se reveló negativo a la expresión del receptor Fc gama de IgG, hallándose solo positividad en algunos fibroblastos $\mathrm{y}$ en macrófagos del tejido conectivo endometrial (ver figura 14).

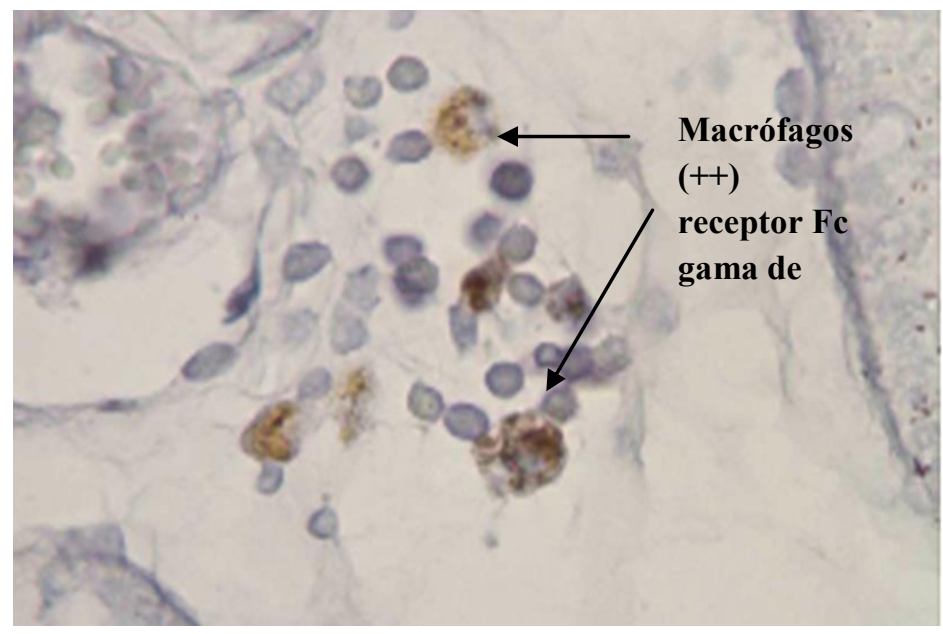

Figura 14: Útero no gestante. Se observan macrófagos positivos al receptor Fc gama de IgG. IHQ 40x 
A los 30 días de gestación encontramos abundante inmunoexpresión del receptor Fc gama de IgG $(+++)$ sobre las células trofoblásticas y en las células epiteliales uterinas, hacia el lumen de la interfase feto materno $(+++)$. Además, en el citoplasma de las células del epitelio glandular se observó expresión (++) del receptor Fc gama (ver figura 15 y 16).

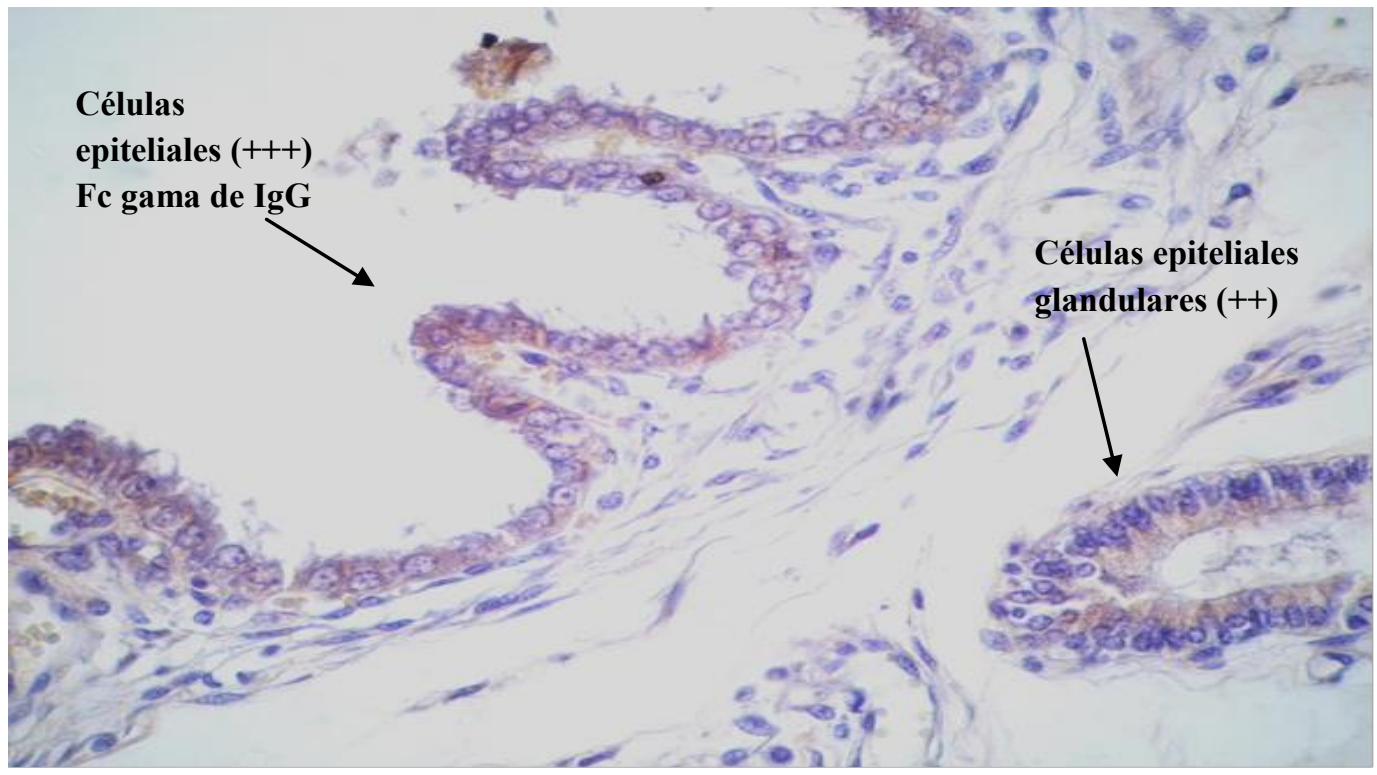

Figura 15: Placenta materna de 30 días de gestación. Inmunomarcaje positivo $(+++)$ a $\mathrm{Fc}$ gama en vellosidades $\mathrm{y}(++)$ en glándulas maternas. IHQ 40x

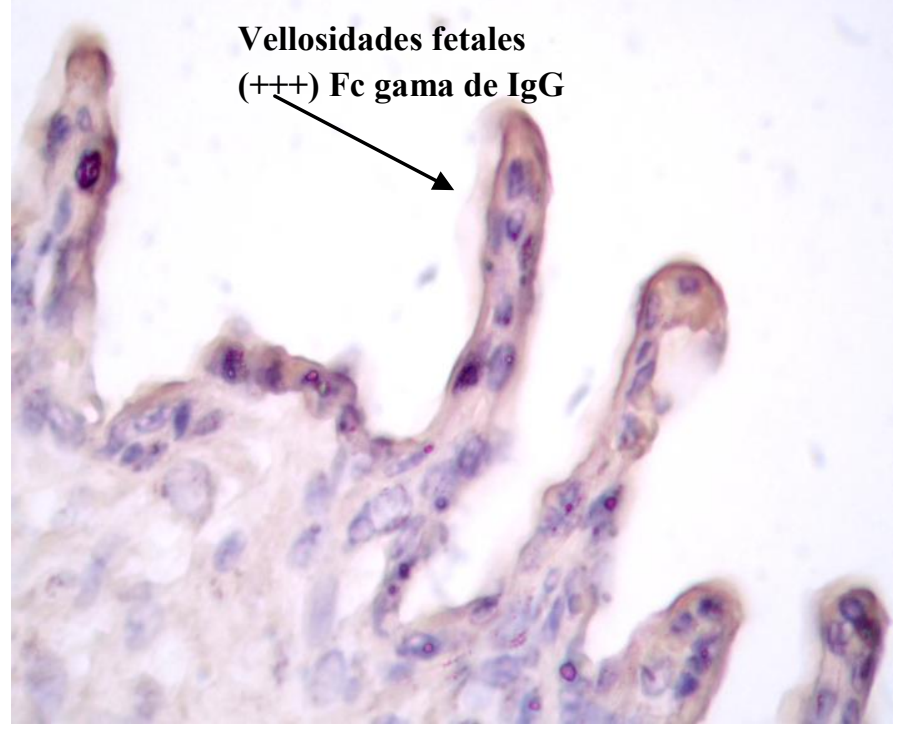

Figura 16: Placenta fetal de 30 días de gestación. Inmunomarcaje positivo $(+++)$ a $\mathrm{Fc}$ gama en vellosidades trofoblásticas. IHQ 100x 
A los 65-70 días de preñez hallamos expresión del receptor Fc gama (+++) en las vellosidades maternas y en las vellosidades fetales $(+++)$. La inmunoreacción que recubría la membrana luminal de las células epiteliales uterinas se encontraba dispuesta en forma lineal, en zonas demarcadas tipo parches. Aproximadamente la mitad de las glándulas endometriales presentaban 2 o 3 células epiteliales con inmunoexpresión (++) al receptor Fc gama. Además, también se observó positividad al receptor $(++)$ en la secreción presente en el lumen de dichas glándulas.

En placenta fetal, a los 70 días de gestación, se observó inmunoexpresión del receptor Fc gama en la membrana apical de las células del epitelio trofoblástico $(+++)$ (ver figura 17). En la figura 18, a mayor aumento, se aprecia el inmunomarcaje positivo al receptor Fc gama de $\operatorname{IgG}$ en células trofoblásticas. 


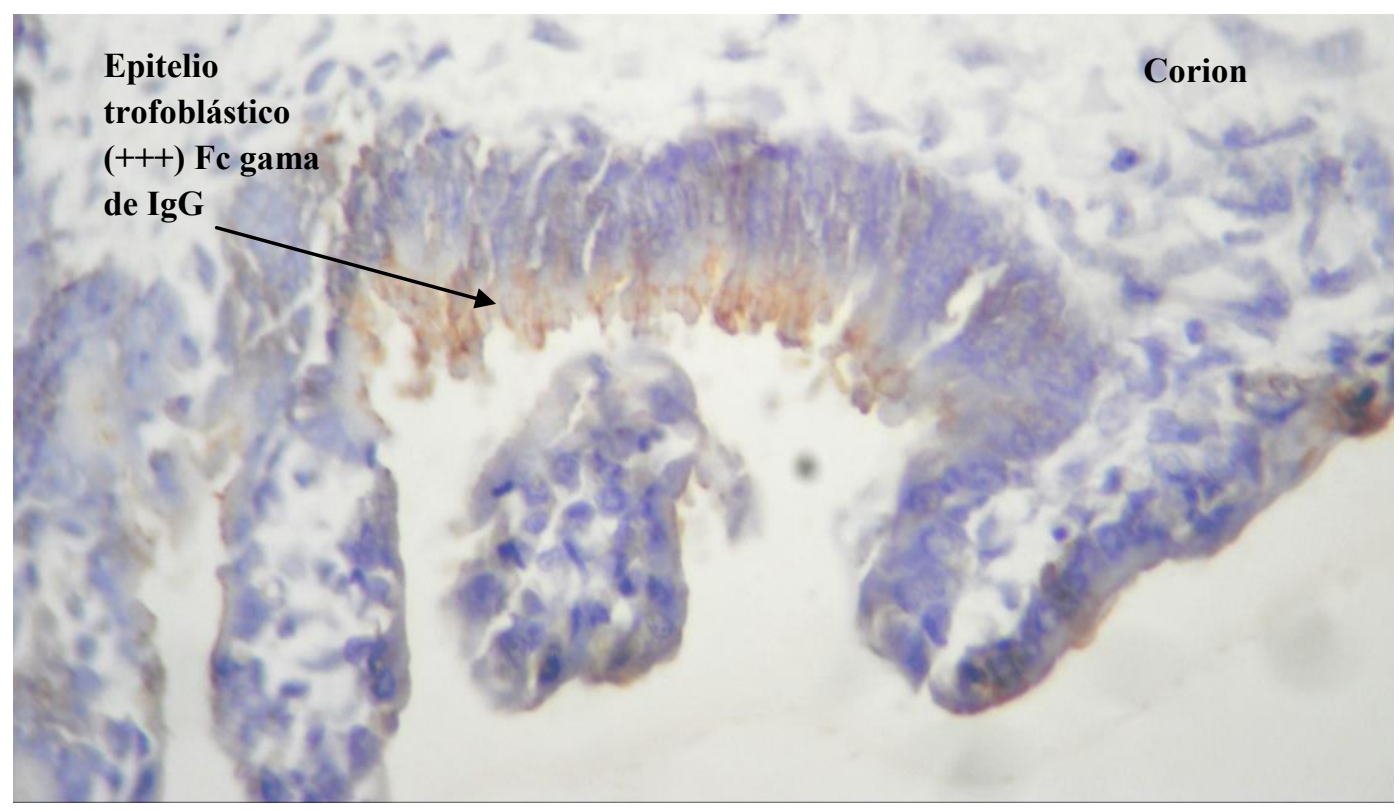

Figura 17: Placenta fetal de 70 días de gestación. Inmunoreacción a Fc gama en vellosidades fetales. IHQ 40x

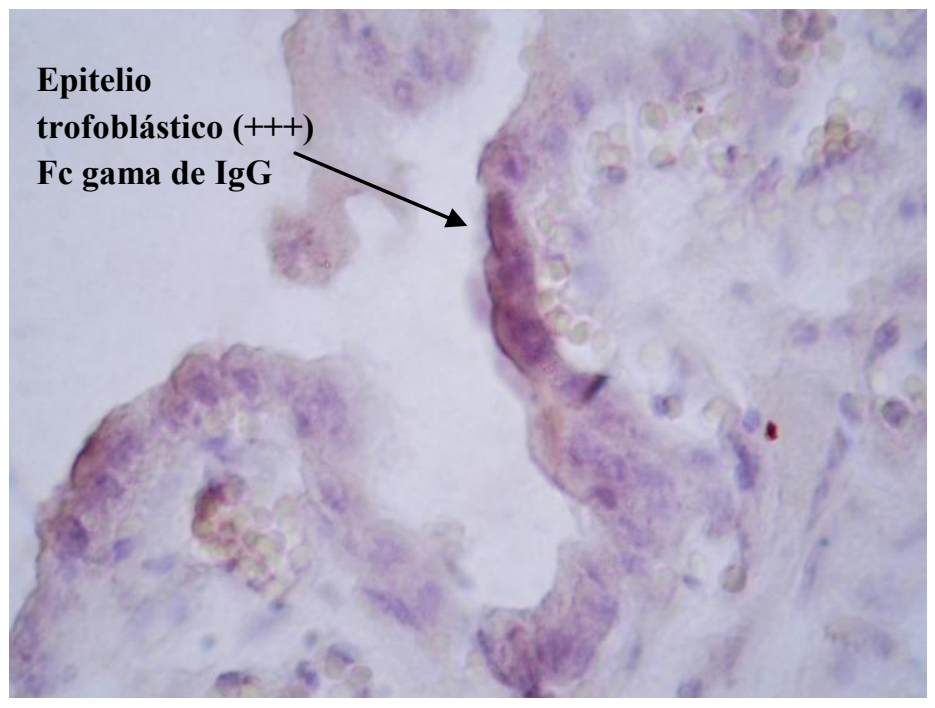

Figura 18: Placenta fetal de 70 días de gestación. Inmunoreacción a $\mathrm{Fc}$ gama en vellosidades fetales. IHQ 100x 
En la gestación a término, encontramos positividad al receptor Fc gama en las vellosidades que conforman la interfase feto materna y ausencia de expresión del receptor en las glándulas endometriales. En el epitelio de las vellosidades fetales se distingue inmunomarcación positiva puntual (+++) al receptor Fc gama de IgG (ver figura 19 y 20 ).

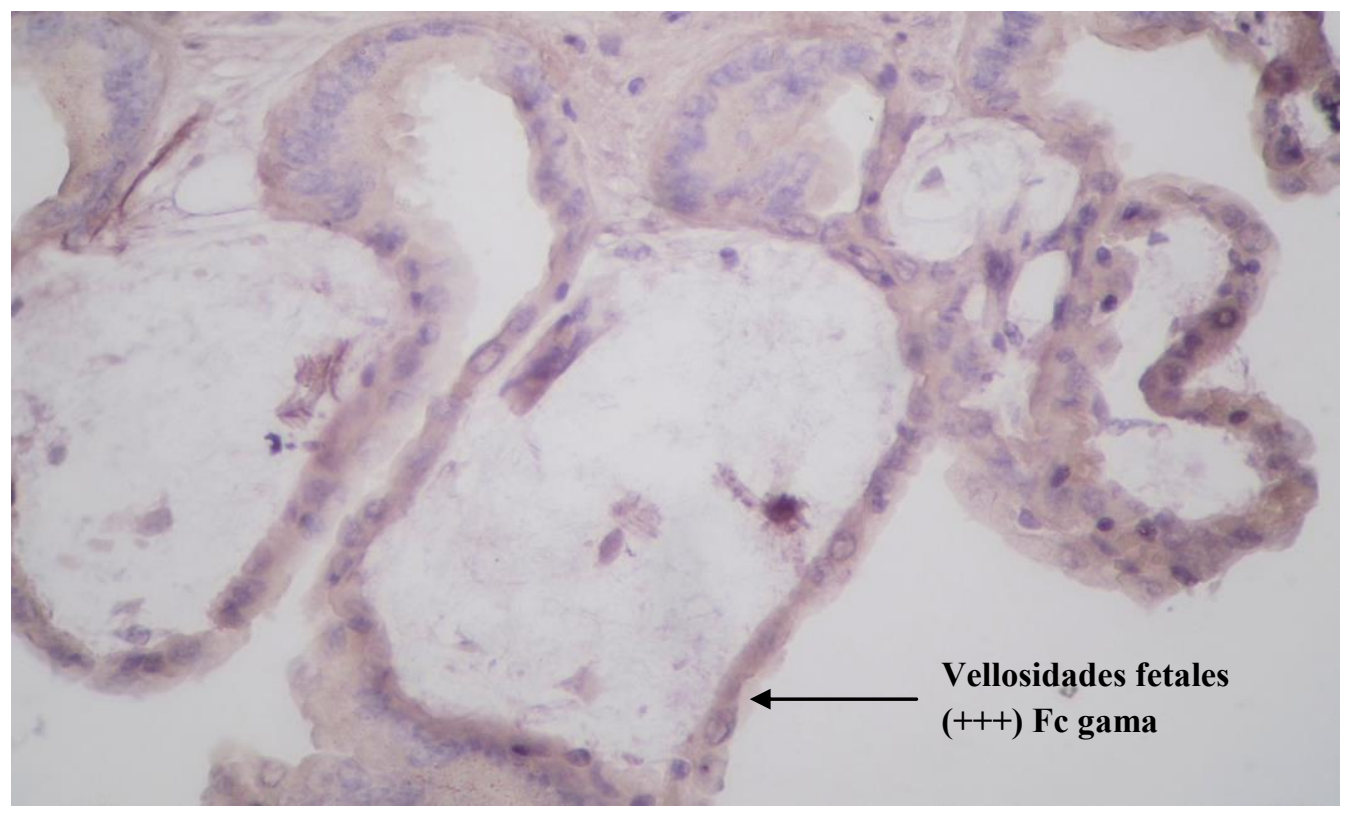

Figura 19: Placenta a término. Inmunomarcación positiva (+++) a Fc gama en vellosidades fetales. IHQ 40x

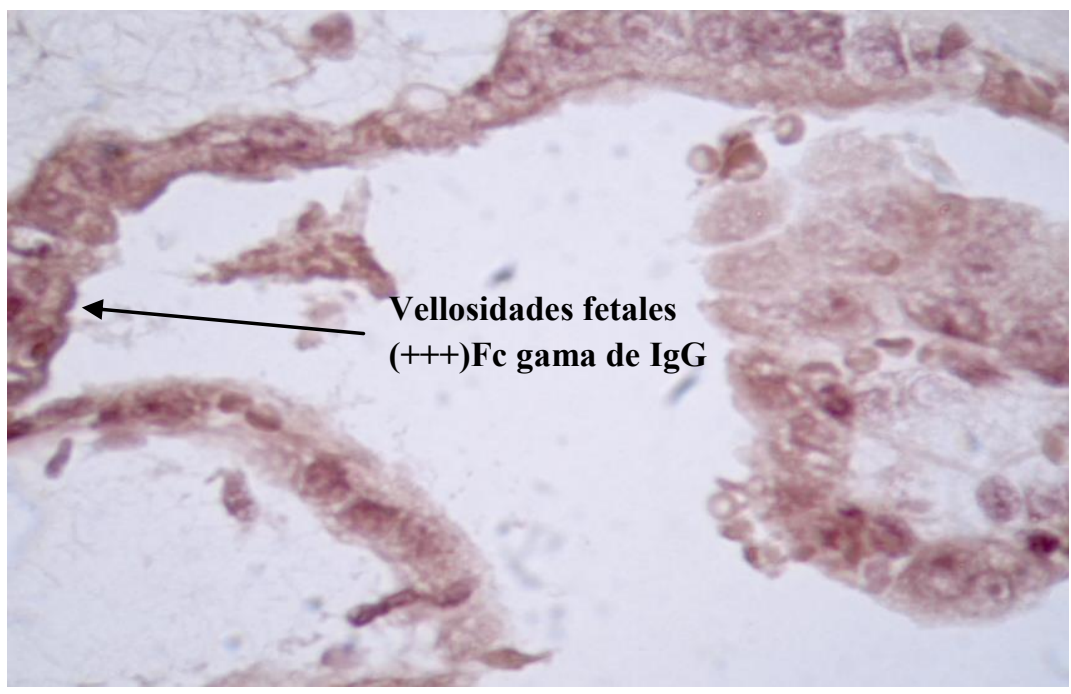

Figura 20: Placenta a término. Inmunomarcación positiva $(+++)$ a Fc gama en vellosidades fetales. IHQ $100 \mathrm{x}$ 


\section{Determinación de anticuerpos IgG asimétricos}

Se determinó la presencia de anticuerpos IgG asimétricos en sueros, en homogenatos de úteros de cerdas vacías y en homogenatos de extractos placentarios maternos y fetales de los distintos períodos gestacionales seleccionados (Tabla 3a, 3b y 3c, Anexo 1).

\section{Determinación de Ac IgG asimétricos en suero}

En la Tabla 4 (Anexo 1) se comparan los porcentajes de Ac IgG asimétricos en suero entre cerdas

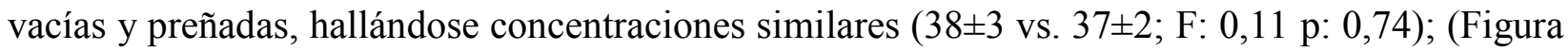
21).

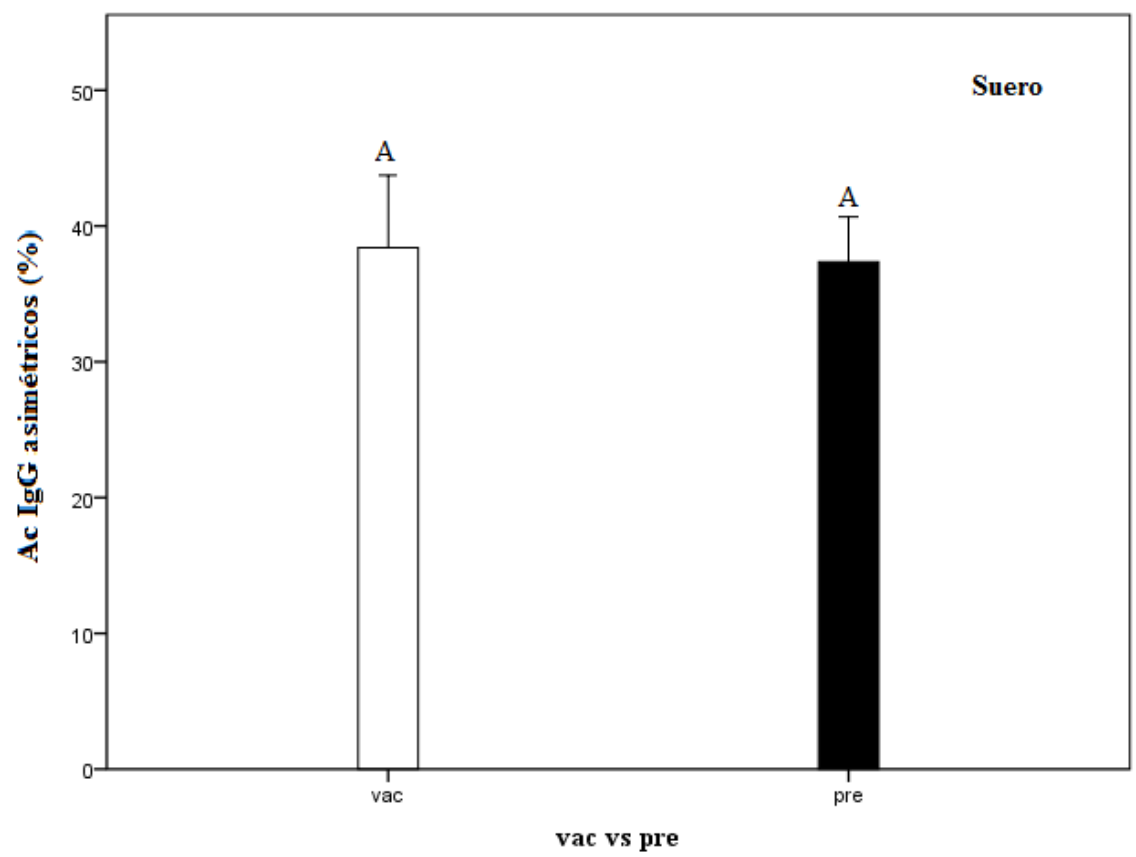

Figura 21: Porcentaje de anticuerpos $\operatorname{IgG}$ asimétricos en sueros en función de si las cerdas estaban vacías (vac) o preñadas (pre).

Se realizó un análisis de la varianza del porcentaje de Ac IgG asimétricos en muestras de suero, hallando resultados similares entre cerdas vacías y de 30 días de gestación $(38 \pm 3$ vs $32 \pm 3$, p: 
0,12). También fueron similares los porcentajes de Ac IgG asimétricos en suero entre cerdas

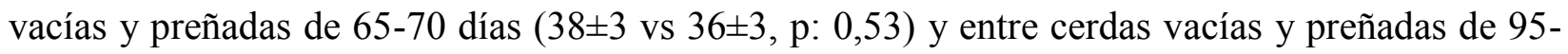

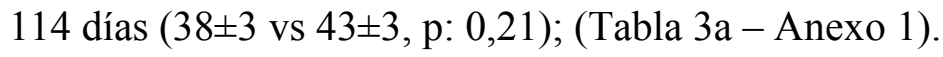

Se realizó un test de Tukey para evaluar las diferencias de medias de los porcentajes de Ac IgG asimétricos dosados en suero entre cerdas vacías y preñadas en los diferentes períodos gestacionales. Se hallaron diferencias significativas solo entre las cerdas de 30 días versus 95-114 días (32 \pm 3 vs $43 \pm 3$, p: 0,01). Para las cerdas de 65-70 días (36 \pm 3$)$ no se encontraron diferencias con los restantes grupos (Figura 22 - Tabla 5 - Anexo 1).

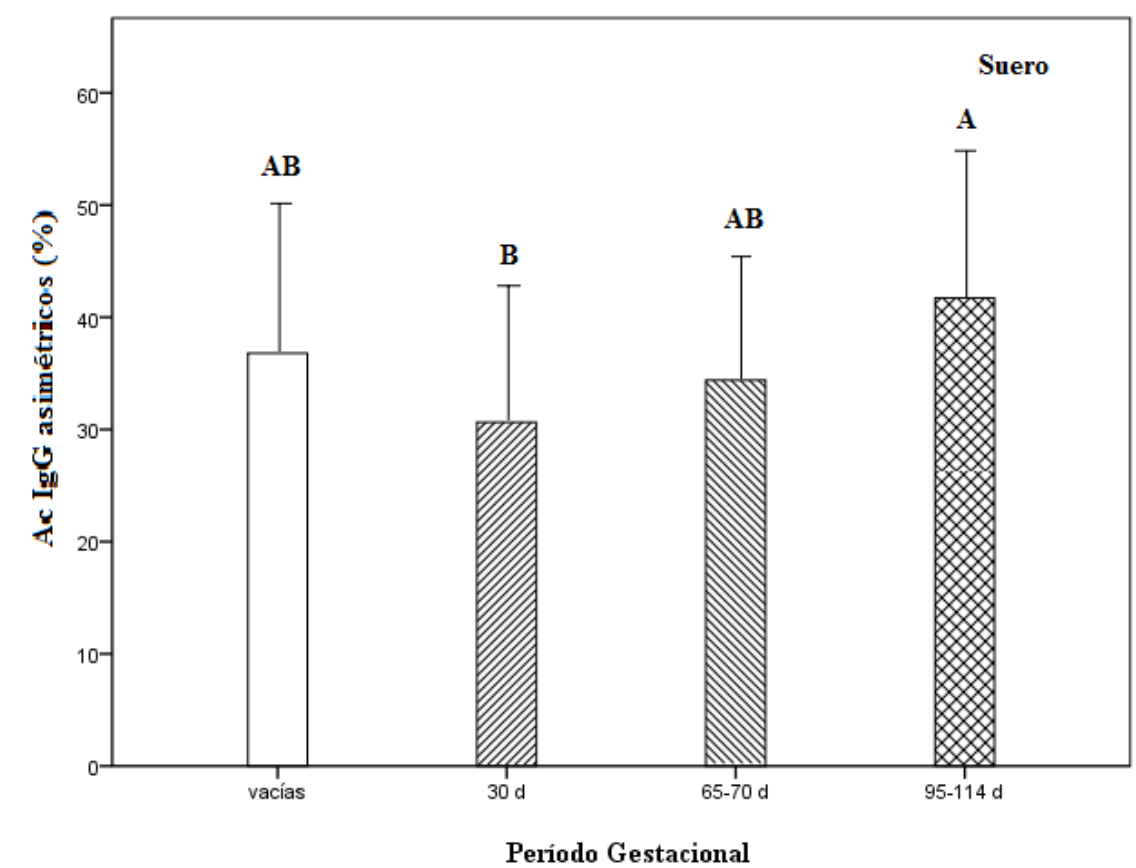

Figura 22: Porcentaje de anticuerpos IgG asimétricos en muestras de suero en función de los períodos gestacionales (vacías, 30 d, 65-70 d, 95-114 d). Barras con diferentes letras denotan diferencias significativas $(\mathrm{p}<0,05)$. 


\section{Determinación de Ac IgG asimétricos en Homogenatos de Placenta Materna}

Se hallaron diferencias significativas en los porcentajes de Ac IgG asimétricos en muestras de homogenatos de placenta materna en los diferentes períodos gestacionales.

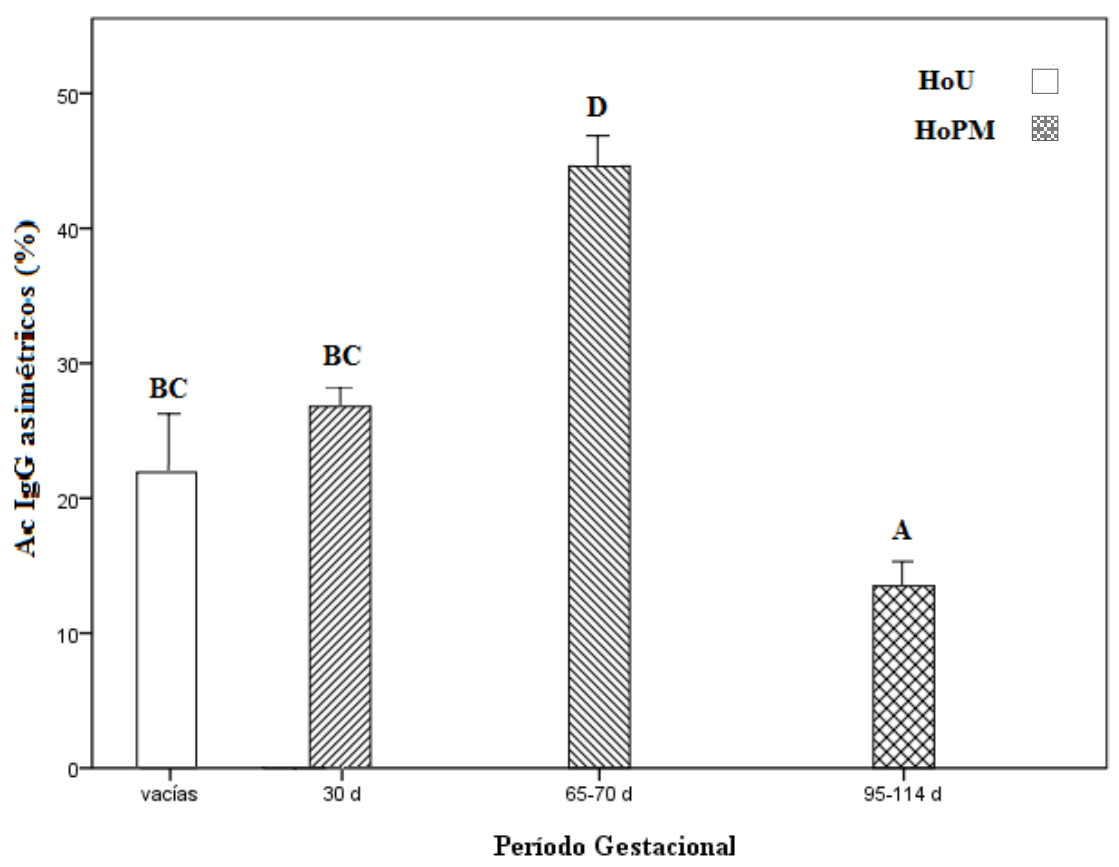

Figura 23: Porcentaje de anticuerpos IgG asimétricos en muestras de HoU (vacías) y en muestras de homogenatos placentarios maternos de los períodos gestacionales seleccionados (30 d, 65-70 d, 95-114 d). Barras con diferentes letras denotan diferencias significativas $(\mathrm{p}<0,05)$.

Se realizó un Test de Tukey, como prueba de comparaciones múltiples, hallándose diferencias significativas en el porcentaje de Ac IgG asimétricos en homogenatos de placenta materna entre cerdas de 65-70 días y de 95-114 días. Se determinarón los siguientes valores de media más menos el error estándar, en muestras de homogenatos de utero no gestante $(20,50 \pm 6)$, en 
homogenatos de placenta porcina de 30 días (27 \pm 2$)$, homogenatos de placenta porcina de 65-70

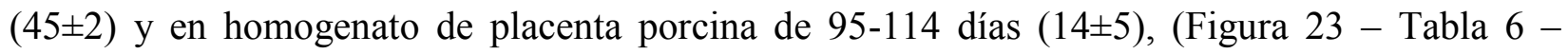
Anexo 1).

\section{Determinación de Ac IgG asimétricos en Homogenatos de Placenta Fetal}

No se observaron diferencias significativas en el porcentaje de Ac IgG asimétricos en homogenatos de placenta fetal entre los distintos períodos gestacionales estudiados (p: 0,4153) 30

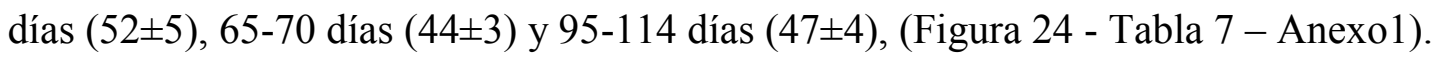

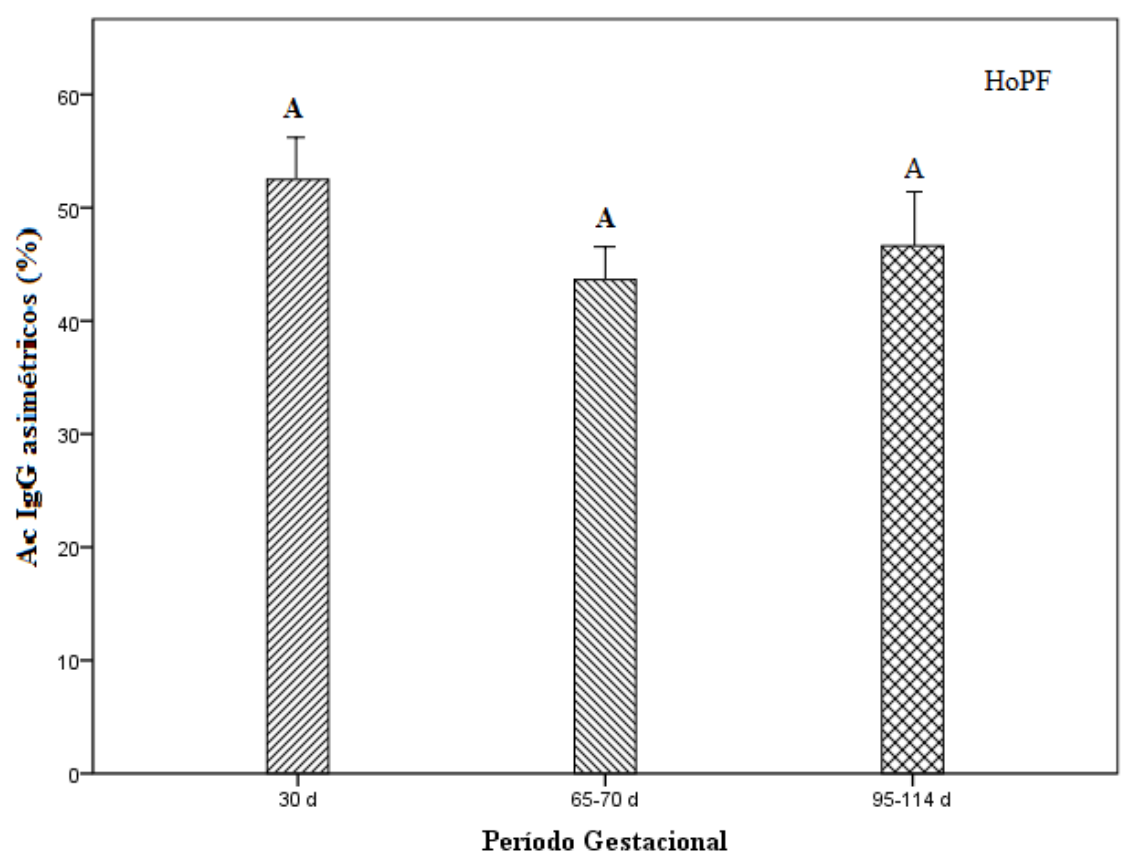

Figura 24: Porcentaje de anticuerpos IgG asimétricos en muestras de HoPF en función de los períodos gestacionales $(30 \mathrm{~d}, 65-70 \mathrm{~d}, 95-114 \mathrm{~d})$. Barras con diferentes letras denotan diferencias significativas $(\mathrm{p}<0,05)$. 


\section{Cuantificación de proteínas totales, albúmina y de IgG}

Se realizó la determinación de proteínas totales, albúmina e $\operatorname{IgG}$ en muestras de suero, HoU, HoPM y HoPF. Se analizaron las variaciones halladas en la concentración de IgG según dos técnicas de precipitación: inmunodifusión radial e inmunoturbidimetría.

\section{Cuantificación de PrT, Alb y de IgG en suero}

En la Tabla 8 se presenta un análisis descriptivo de las variaciones de las concentraciones de Proteínas Totales, en la Tabla 9 de la concentración de Albumina, en la Tabla 10 de la concentración de $\operatorname{IgG}$ determinado mediante Inmunoturbidimetría y en la Tabla 11 de la concentración de $\operatorname{IgG}$ determinado mediante Inmunodifusión Radial en cerdas vacías y en los diferentes períodos gestacionales estudiados (Anexo).

Se encontraron diferencias significativas entre hembras vacías y preñadas en suero para la variable Proteínas Totales (8.681 \pm 395 vs $7.591 \pm 163$, F: 6,52; p: 0,0140) (Figura 25 - Tabla 12Anexo 2). 


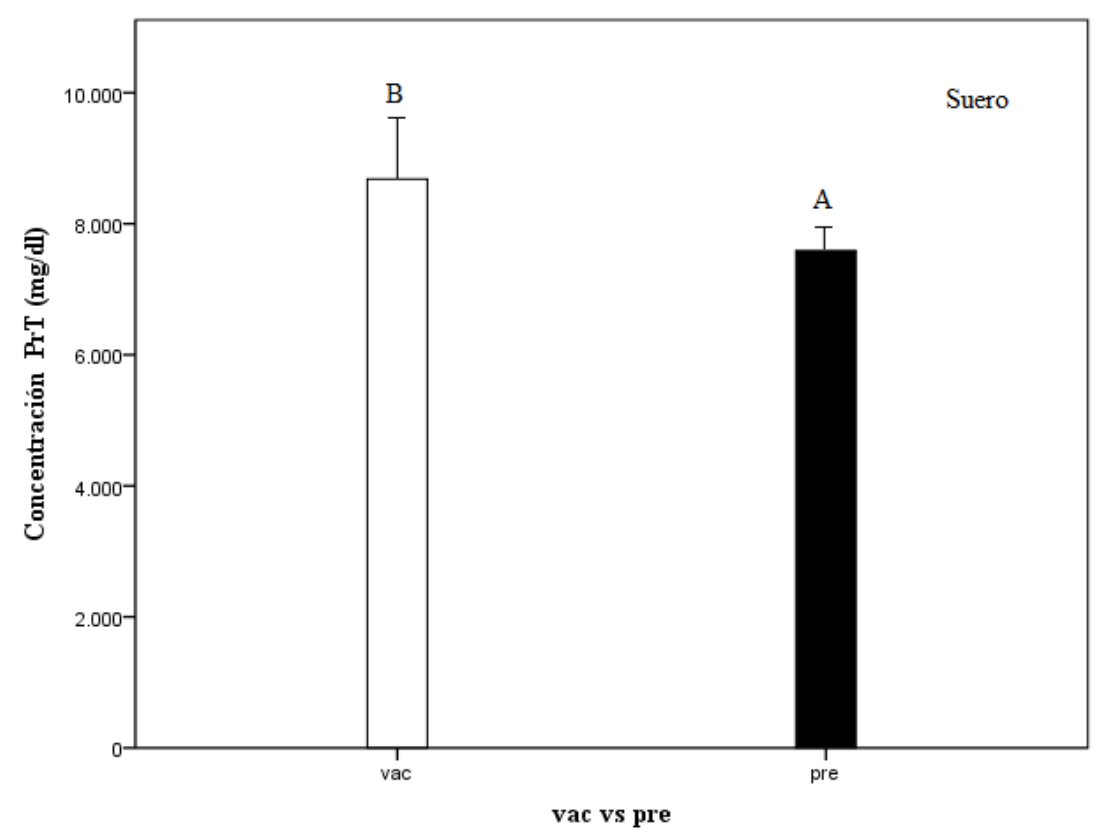

Figura 25: Concentración de Proteínas Totales $(\mathrm{mg} / \mathrm{dl})$ en muestras de suero entre cerdas vacías y preñadas. Barras con diferentes letras denotan diferencias significativas $(p<0,05)$.

Las concentraciones séricas de Proteínas Totales fueron similares entre cerdas de 30 días y de 6570 días $(7.517 \pm 205$ vs $7.968 \pm 330)$. Se hallaron diferencias significativas entre cerdas vacías y de

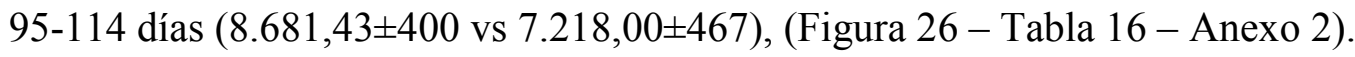




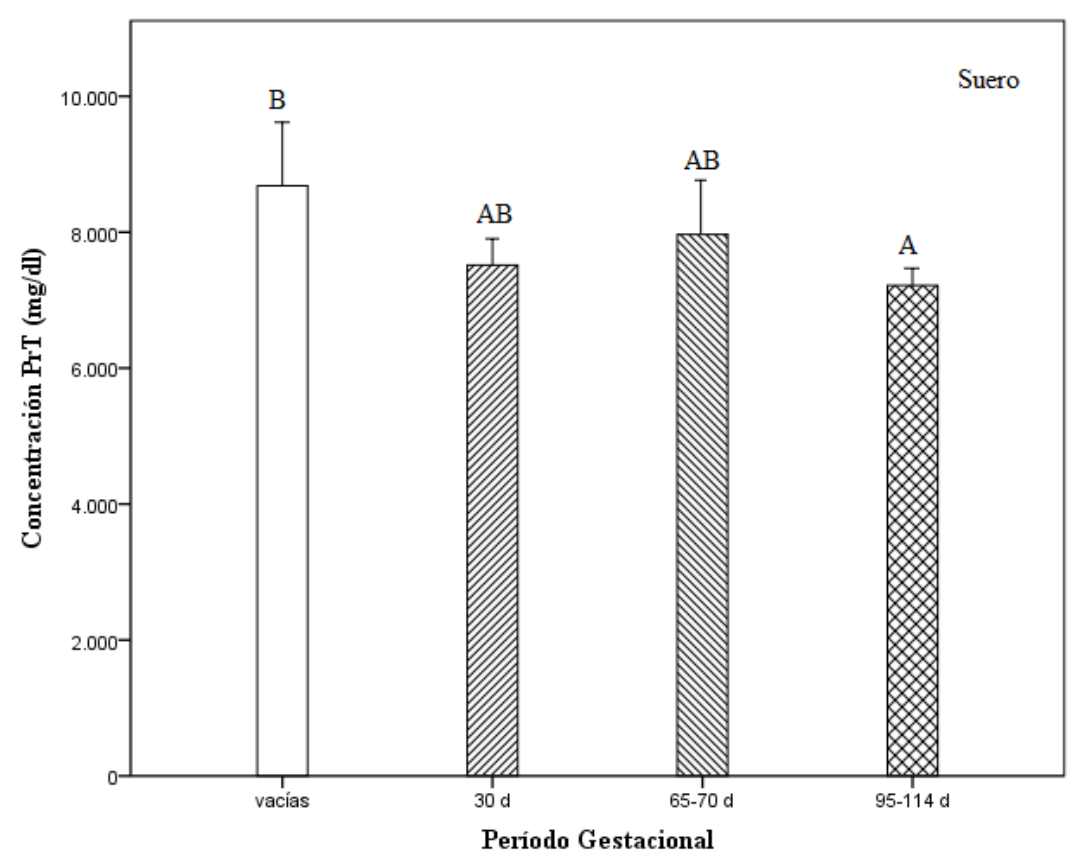

Figura 26: Concentración sérica de Proteínas Totales (mg/dl) entre cerdas vacías y de diferentes períodos gestacionales (vacías, 30 d, 65-70 d, 95-114 d). Barras con diferentes letras denotan diferencias significativas $(\mathrm{p}<0,05)$.

No se encontraron diferencias significativas en suero entre hembras vacías y preñadas para la variable albúmina (3.972 \pm 300 vs $3.706 \pm 133$, p: 0,4210); (F: 0,66), (Tabla 13, Anexo 2).

Las concentraciones séricas de Albúmina fueron similares entre cerdas vacías (3.972 \$306), 30

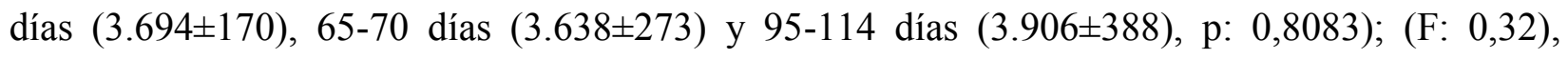
(Tabla 17 - Anexo 2). 
Se encontraron diferencias significativas en suero entre hembras vacías y preñadas para la variable IgG determinado mediante Inmunoturbidimetría ( $731 \pm 57$ vs $603 \pm 27$, p: 0,0483) (F: 4,17) (Figura 27 - Tabla 14 - Anexo 2).

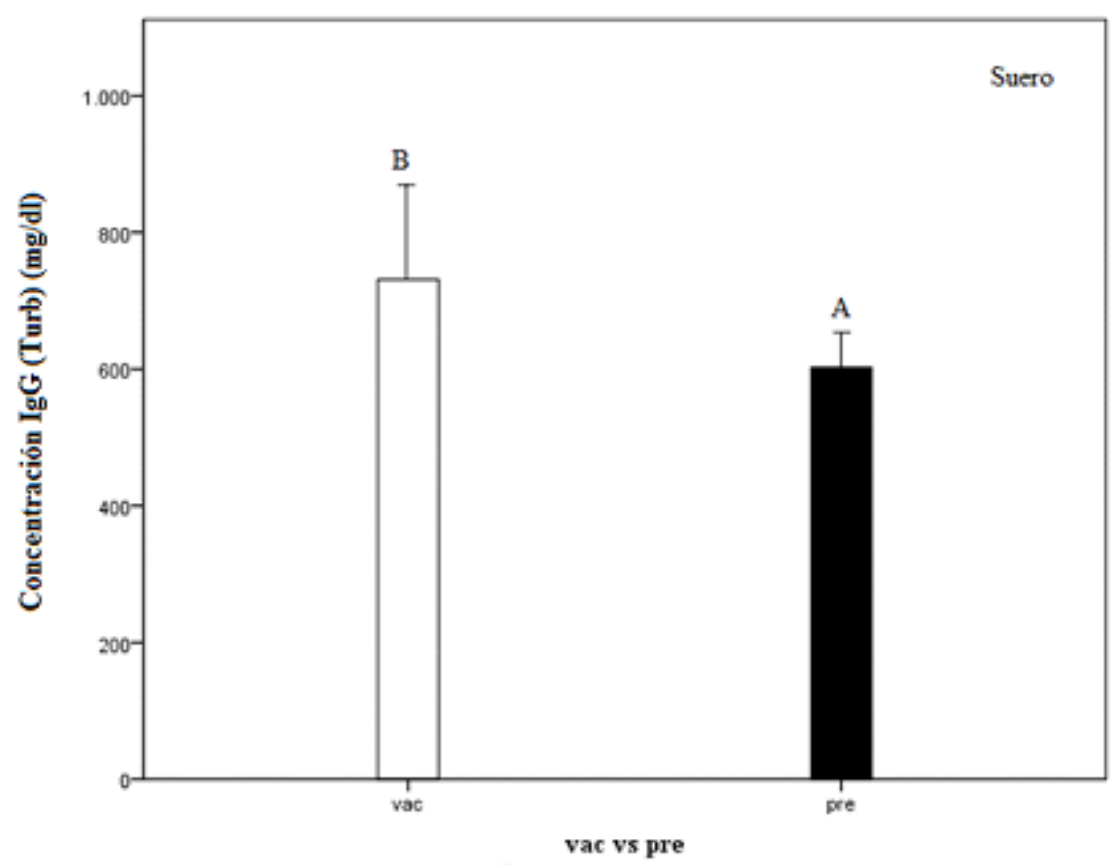

Figura 27: Concentración de $\operatorname{IgG}$ (Turb) $(\mathrm{mg} / \mathrm{dl})$ en muestras de suero entre cerdas vacías y preñadas. Barras con diferentes letras denotan diferencias significativas $(p<0,05)$.

Las concentraciones séricas de IgG determinado mediante Inmunoturbidimetría fueron similares

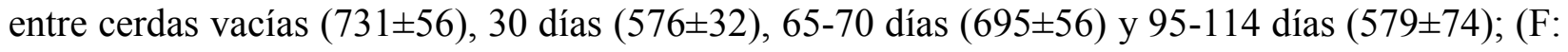
2,60; p: 0,0672, (Tabla $18-$ Anexo 2). 
También se encontraron diferencias significativas en suero entre hembras vacías y preñadas para

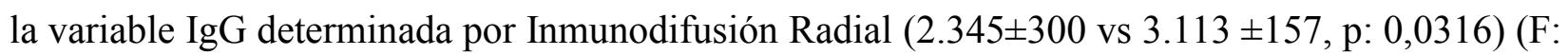
5,16); (Figura 28 - Tabla 15 - Anexo 2).

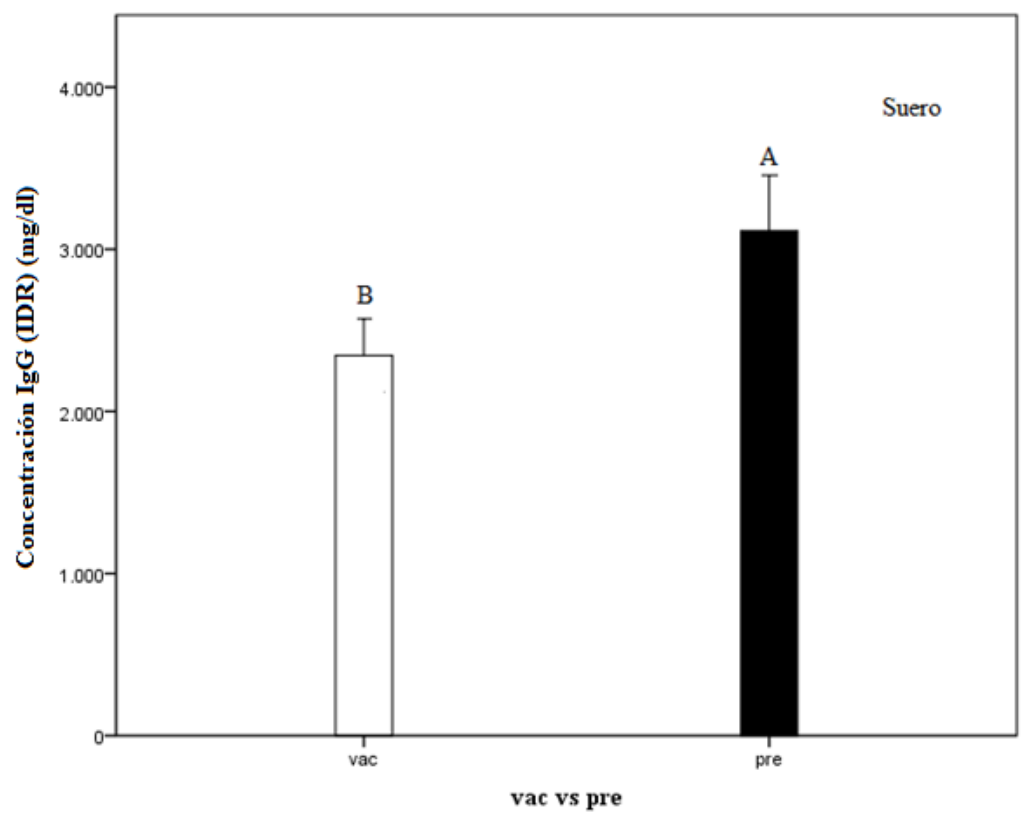

Figura 28: Concentración de IgG determinada por Inmunodifusión Radial (mg/dl) en muestras de suero entre cerdas vacías y preñadas. Barras con diferentes letras denotan diferencias significativas $(\mathrm{p}<0,05)$.

Las concentraciones séricas de IgG determinada por Inmunodifusión Radial fueron diferentes

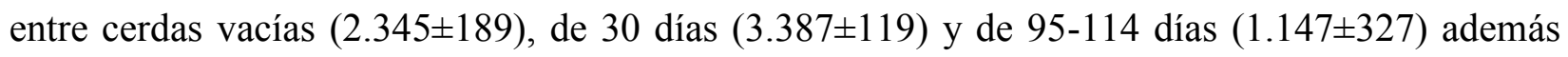

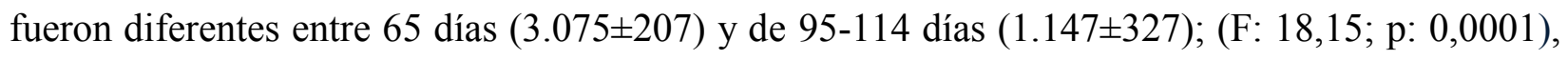
mientras que las concentraciones entre cerdas vacías vs cerdas de 65-70 días fueron similares. (Figura 29 - Tabla 19 - Anexo 2). 


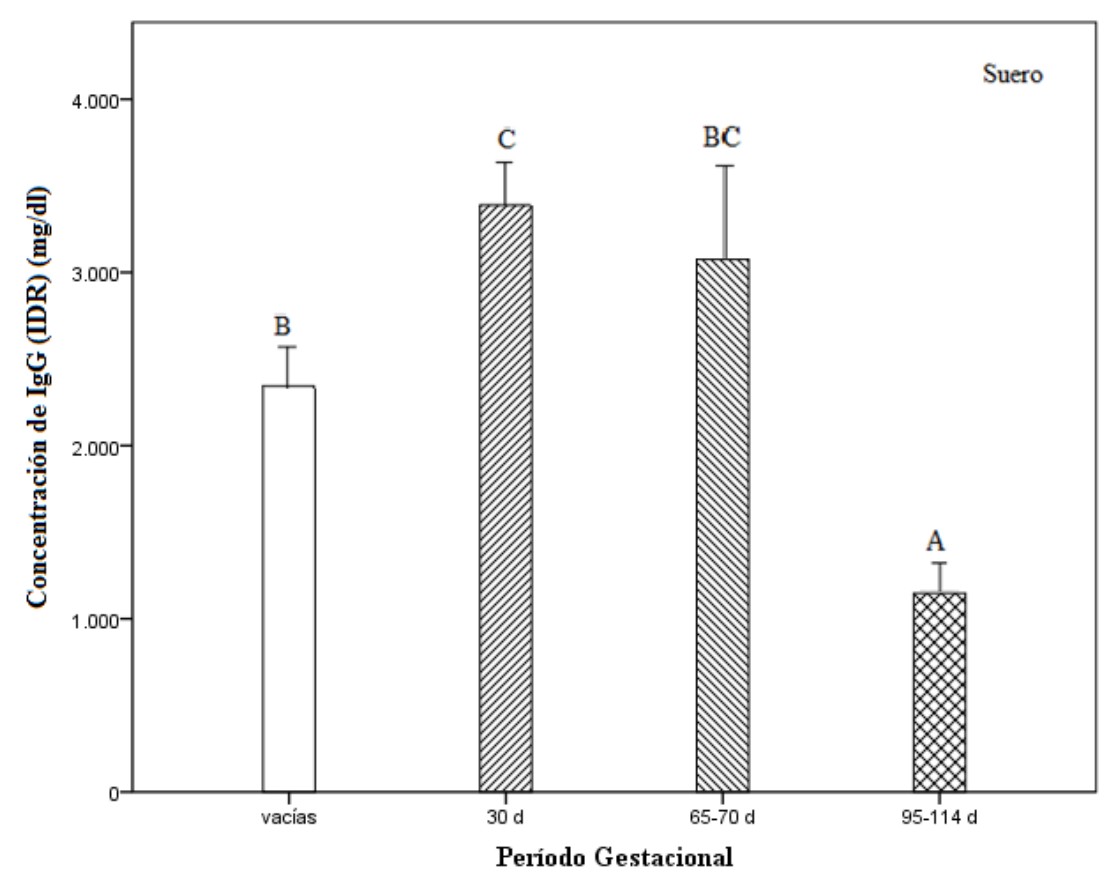

Figura 29: Concentración sérica de IgG determinada por Inmunodifusión Radial en mg/dl entre cerdas vacías y de diferentes períodos gestacionales (vacías, 30 d, 65-70 d, 95-114 d). Barras con diferentes letras denotan diferencias significativas $(\mathrm{p}<0,05)$. 


\section{Correlación y Regresión lineal entre IgG determinada por Inmunodifusión Radial e IgG determinada por Inmunoturbidimetría}

Dada la discordancia de valores hallados en la determinación de IgG por los dos métodos utilizados, se calculó la regresión lineal y correlación entre IgG por Inmunodifusión Radial e IgG por Inmunoturbidimetría. La correlación no fue significativa entre las variables IgG por Inmunoturbidimetría e IgG determinada por Inmunodifusión Radial (r: 0,46; p: 0,13), lo cual explicaría los resultados contradictorios de concentración de IgG determinada por los dos métodos y la regresión lineal obtenida (Figura 30).

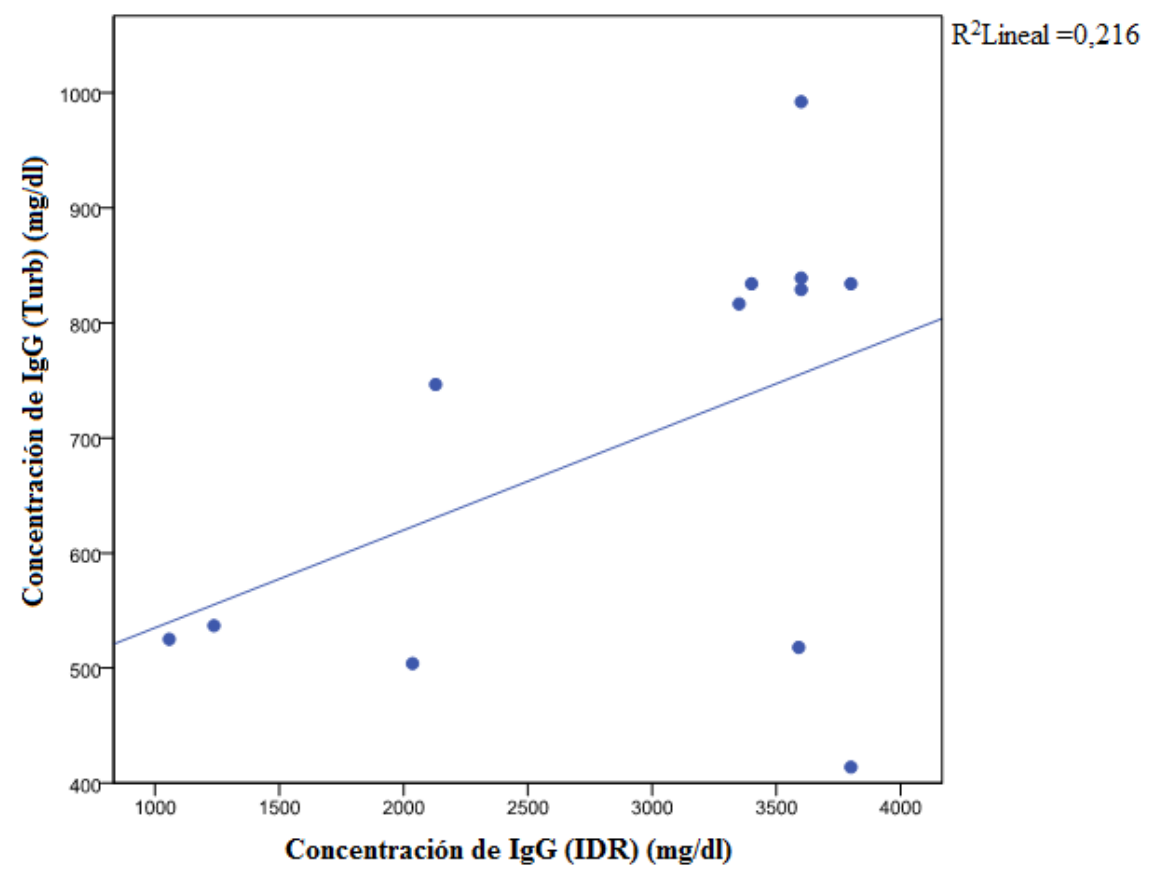

Figura 30: Regresión lineal de IgG (Turb) en función de IgG (IDR) (p: 0,1278, $\mathrm{R}^{2}$ : 0,22). 


\section{Cuantificación de Proteínas Totales y de IgG determinada por Inmunoturbidimetría en}

\section{homogenatos placentarios maternos}

Se determinó la presencia de Proteínas Totales y de IgG determinada por Inmunoturbidimetría en homogenatos de úteros de cerdas vacías y en homogenatos de extractos placentarios maternos de los distintos períodos gestacionales seleccionados.

En la Tabla 20 se presenta el análisis descriptivo de las concentraciones de Proteínas Totales $(\mathrm{mg} / \mathrm{dl})$ en homogenatos de úteros de cerdas vacías y en homogenatos de extractos placentarios maternos de cerdas en los diferentes períodos gestacionales estudiados. En la Tabla 21 se presenta un análisis descriptivo de la concentración de IgG determinada por Inmunoturbidimetría en homogenatos de úteros de cerdas vacías y en homogenatos de extractos placentarios maternos de cerdas en los diferentes períodos gestacionales estudiados (Anexo 2).

No se encontraron diferencias significativas entre las concentraciones de Proteínas Totales en homogenatos de útero de cerdas vacías y el conjunto de homogenatos de extractos placentarios

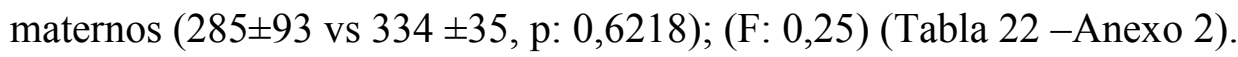

Se encontraron diferencias significativas en la concentración de Proteínas Totales en muestras de homogenatos de extractos placentarios maternos de cerdas de 65-70 días de gestación (598 \pm 66 ) contra el resto de los períodos gestacionales: 30 días $(280 \pm 39)$ y 95-114 días $(271 \pm 49)$ y cerdas

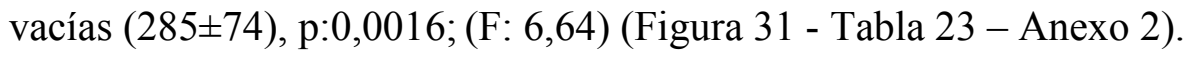




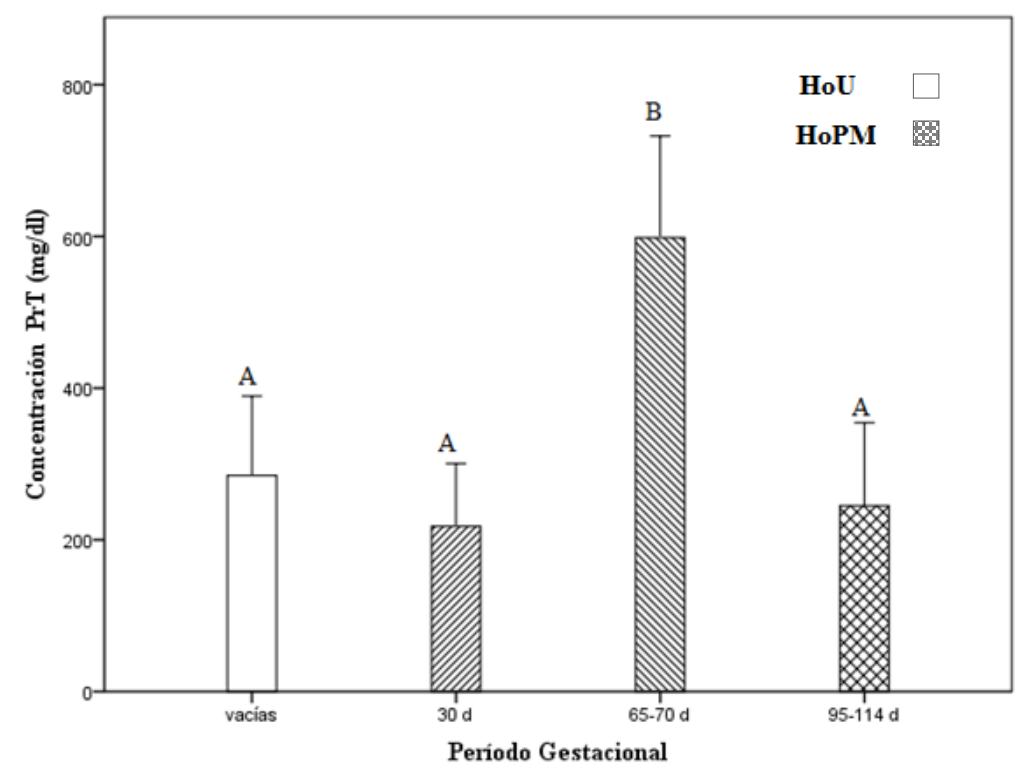

Figura 31: Concentración de $\operatorname{PrT}(\mathrm{mg} / \mathrm{dl})$ en hembras vacías (HoU) y en los diferentes períodos gestacionales (30 d, 65-70 d, 95-114 d). Barras con diferente letras denotan diferencias significativas $(\mathrm{p}<0,05)$.

Se encontraron diferencias significativas en las concentraciones de IgG determinada por Inmunoturbidimetría en homogenatos de útero de cerdas vacías con respecto a los homogenatos de extractos placentarios maternos ( $87 \pm 8$ vs $36 \pm 3$, p: 0,0001). (F: 38,41; p: $<0,0001)$ (Figura 32 Tabla 24 - Anexo 2). 


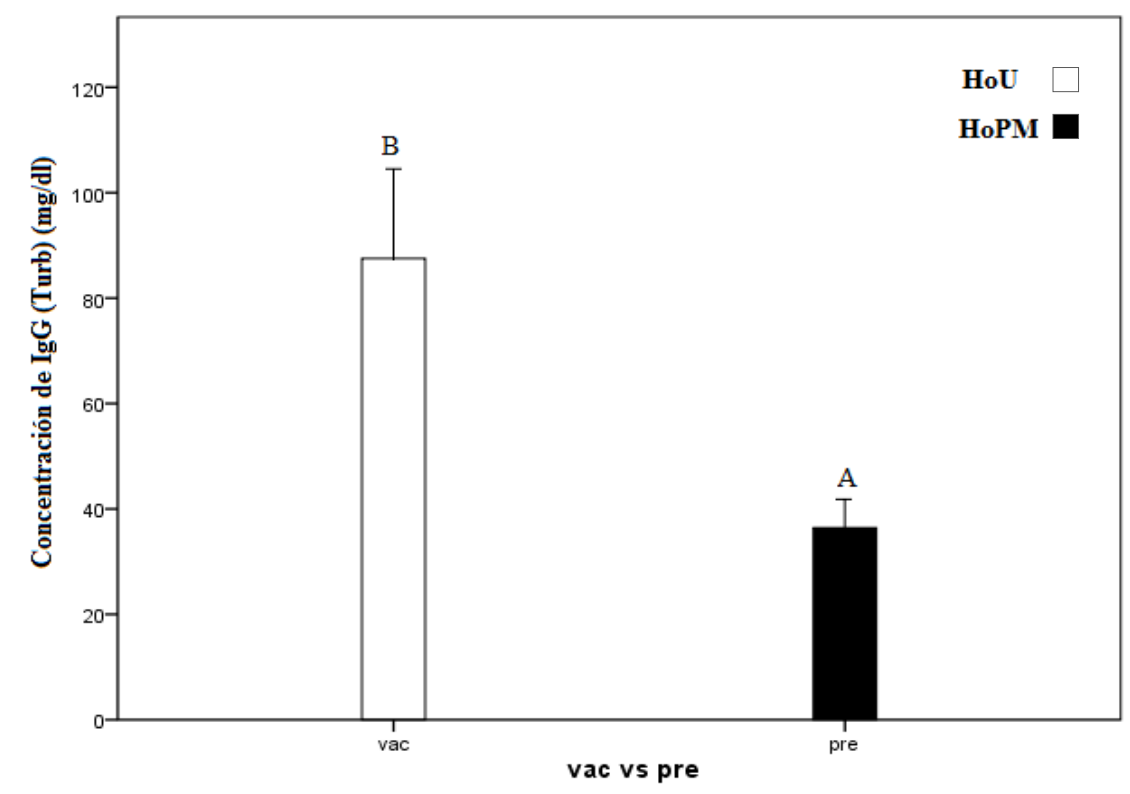

Figura 32: Concentración de $\operatorname{IgG}(\mathrm{Turb})(\mathrm{mg} / \mathrm{dl})$ en homogenatos de útero de cerdas vacías y en homogenatos de extractos placentarios maternos. Barras con diferentes letras denotan diferencias significativas $(\mathrm{p}<0,05)$.

Se realizó un Test de Tuckey para observar las diferencias significativas de las medias. Se encontraron diferencias significativas en las concentraciones de IgG determinada por Inmunoturbidimetría entre cerdas vacías $(87 \pm 8)$ y preñadas en diferentes períodos gestacionales;

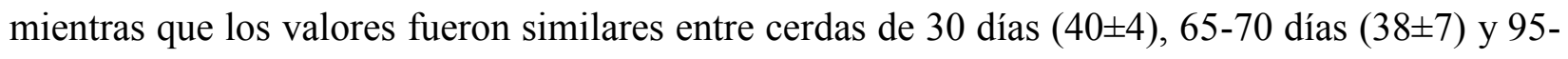

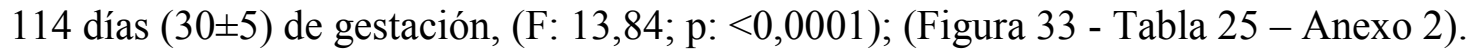




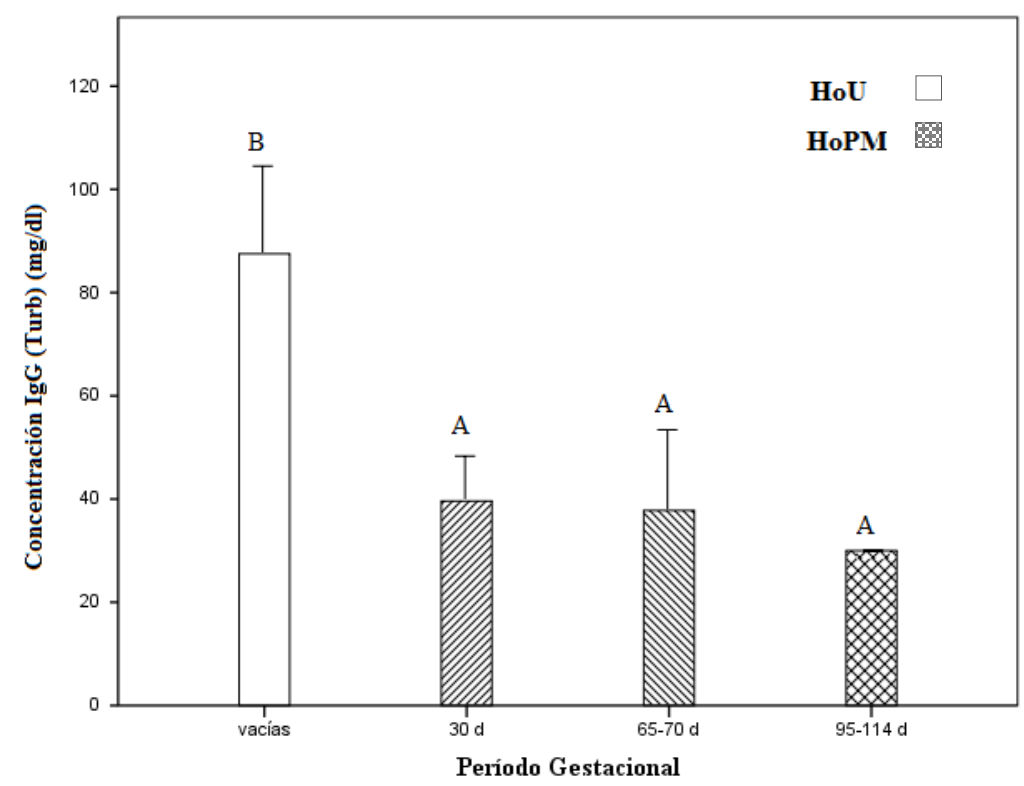

Figura 33: Concentración de $\mathrm{IgG}$ (Turb) (mg/dl) en hembras vacías (HoU) y en los diferentes períodos gestacionales (30 d, 65-70 d, 95-114 d). Barras con diferente letras denotan diferencias significativas $(\mathrm{p}<0,05)$.

Cuantificación de Proteínas Totales y de IgG determinada por Inmunodifusión Radial en homogenatos placentarios maternos

Se determinó la presencia de IgG mediante Inmunodifusión Radial en homogenatos de útero de cerdas vacías y en homogenatos de extractos placentarios maternos de los distintos períodos gestacionales seleccionados.

En la Tabla 26 se presenta el análisis descriptivo de las concentraciones de IgG determinada por Inmunodifusión Radial en homogenatos de útero de cerdas vacías comparado con los resultados de los homogenatos de extractos placentarios maternos de cerdas de 95-114 días de gestación. 
No se encontraron diferencias significativas en la concentración de IgG (IDR) entre cerdas vacías

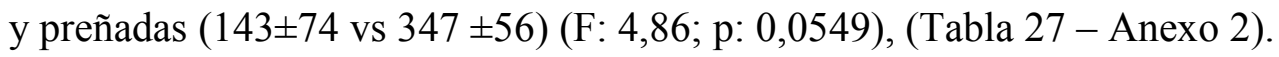

\section{Cuantificación de Proteínas Totales y de IgG mediante Inmunoturbidimetría en homogenatos placentarios fetales}

Se realizó un análisis descriptivo de la concentración de Proteínas Totales en homogenatos placentarios fetales en diferentes períodos gestacionales (Tabla 28, Anexo 2).

En la Tabla 29 se presenta un análisis descriptivo de la concentración de IgG mediante Inmunoturbidimetría en homogenatos placentarios fetales en los diferentes períodos gestacionales estudiados (Anexo 2).

No se encontraron diferencias significativas en la concentración de Proteínas Totales en homogenatos placentarios fetales en los diferentes períodos gestacionales: 30 días (322 \pm 71 , 65-

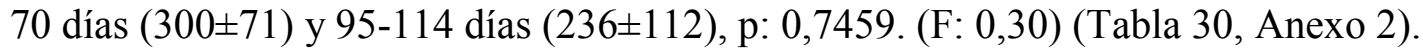

Las concentraciones de IgG mediante Inmunoturbidimetría en homogenatos placentarios fetales

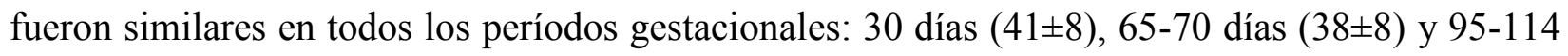

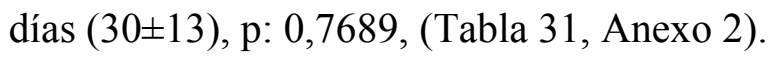

\section{Cuantificación de IgG mediante Inmunodifusión Radial en homogenatos placentarios} fetales

Se realizó un análisis descriptivo de la concentración de IgG (IDR) en homogenatos de cerdas con 95-114 días de preñez (Tabla 32, Anexo 2). Con respecto a los otros períodos evaluados, las concentraciones de IgG no permitieron alcanzar el rango de determinación, debido a la 
sensibilidad del método, por lo tanto no pudieron ser comparados los distintos períodos de gestación estudiados. 


\section{DISCUSIÓN}

En la reproducción, el sistema inmunológico con sus mecanismos celulares y moleculares juega un rol que aún no se comprende en su totalidad. La placenta porcina es un órgano integrado por estructuras de origen fetal y materno, del tipo epiteliocorial y no invasiva, por eso las interacciones entre el epitelio luminal uterino y el trofoblasto son cruciales para el mantenimiento de la gestación.

Surge el interrogante de que ¿por qué el embrión comportándose como un injerto semialogénico, no es rechazado por la madre? Se sabe que la madre produce una activa respuesta inmunológica frente al feto y sin embargo, el rechazo inmunológico no se produce (Barañao, 2010). Diversas investigaciones estudian los mecanismos por los cuales los fetos no son rechazados por su madre.

Está demostrado que el embrión/feto presenta diferentes antígenos de origen materno y paterno, pero no es rechazado en condiciones normales, por lo que el éxito de la preñez depende de las complejas interacciones entre el sistema inmunológico y el resto de los sistemas que componen el organismo materno a fin de preservar la sobrevida de los embriones/fetos. Se piensa que los factores involucrados en la aceptación del aloinjerto fetal y en el mantenimiento del equilibrio inmune durante la preñez dependen del sistema inmune materno y de la síntesis de moléculas moduladoras por parte de la placenta. La placenta, a través de los factores involucrados, que son interdependientes, originaría un estado de tolerancia activa durante la gestación (Barañao, 2010).

La placenta porcina, por su ubicación de barrera entre la madre y los embriones/fetos, es el blanco natural de los sistemas endocrino e inmunitario y de ella depende, a través de las 
interacciones entre el trofoblasto y el epitelio luminal uterino areolar e interareolar, el intercambio de sustancias y nutrientes entre la madre y los embriones a fin de garantizar el éxito de la preñez. Por ello, ha sido caracterizada como un órgano endocrino propio de la gestación que modula la respuesta inmune materna. El sistema endocrino y el sistema inmunológico están estrechamente vinculados, por lo tanto el aumento de los niveles de los esteroides sexuales durante la gestación favorecería la tolerancia materna inhibiendo la acción de células citotoxicas, aumentando la producción de citoquinas antiinflamatorias y por lo tanto favoreciendo la predominancia de una respuesta inmune que beneficiaría a la gestación (Barañao, 2010).

Coincidimos con Chen y col., (2012) en que la interacción inmunológica entre el feto y la madre es una comunicación especial que estaría regulada por la presentación de antígenos del feto, particularmente los presentes en la superficie del trofoblasto, y por el reconocimiento y la reacción a esos antígenos por parte del sistema inmune innato y adquirido de la madre.

En trabajos anteriores realizados en nuestro laboratorio encontramos una gran afinidad por la lectina Con-A (que reconoce residuos $\alpha$-manosa y $\alpha$-Glucosa), en cortes de tejido placentario tanto fetales como maternos de distintos períodos gestacionales, sobre todo en muestras de \pm 55 días de gestación (Koncurat y col., 2004; Zubeldía, 2007; Sanchis y col., 2009). La presencia de dichos residuos en ambas membranas celulares permitirían las interacciones favoreciendo el desarrollo temprano del conceptus y participando en la inhibición de la respuesta inmune materna (Szafranska y col., 2004). Margni (1989) describió que si se someten Ac purificados a cromatografía de afinidad con Con-A - sefarosa se pueden separar los Ac precipitantes (simétricos) de los no precipitantes (o asimétricos), demostrando que un oligosacárido con alto contenido en manosa es el responsable del particular comportamiento 
biológico de los Ac asimétricos que se encuentra unido al fragmento Fab de la molécula de IgG. Otras especies con placenta epiteliocorial, además de la cerda, son la yegua, la burra y los camélidos. Varios estudios han sido realizados para determinar los patrones de glicosilación en las diversas placentas epiteliocoriales a través de su desarrollo, encontrándose que los tejidos uterinos guardan más similitud de expresión de glicanos que los trofoblastos de las diferentes especies (Jones y col.,1997; 2000) sugiriéndose que los glicanos presentes en el trofoblasto son parcialmente controlados por el genotipo del embrión y por las hormonas esteroideas, por lo que suponemos que la respuesta inmunológica que se desarrolla en la interfase feto materna dependerá de la presencia de determinados sacáridos en la superficie de las células trofoblásticas y uterinas en la interfase feto materna. La presencia de residuos $\alpha$-man y $\alpha$-glc determinados con la Con-A en la interfase feto materna en diferentes períodos gestacionales, nos abrió las puertas para comenzar con los estudios de los Ac IgG asimétricos en porcinos.

A partir de nuestros resultados, y al igual que Barañao (2010), pensamos que las citoquinas liberadas por los linfocitos Th2 y la respuesta inmune humoral, desarrollada por los linfocitos B maternos en su doble papel: como células presentadoras de antígenos y como células productoras de anticuerpos, podría ser uno de los factores que permiten la aceptación del aloinjerto fetal durante la gestación porcina mediante un mecanismo de tolerancia materno-fetal.

Pocos estudios evalúan el rol de la respuesta inmune humoral, particularmente la síntesis de anticuerpos, teniendo en cuenta el papel de las diferentes clases de anticuerpos IgG que se producen durante la preñez porcina. Tampoco se conocen los factores que regulan la expresión de los receptores de las IgG ni en el útero ni en la placenta porcina. 
Por lo expuesto, el objetivo de este trabajo fue comprobar la existencia de los anticuerpos asimétricos de la clase IgG en porcinos; identificar la presencia de los distintos tipos de $\operatorname{IgG}$ (simétricos y asimétricos) y de su receptor en tejidos placentarios fetales y maternos, a fin de comprender el rol que podría desempeñar el sistema inmune humoral durante la gestación porcina. Para tal fin, se decidió emplear la técnica de inmunofluorescencia según Bowen y col., (1996) para la determinación de IgG. Durante los primeros ensayos se comprobó que los tejidos placentarios porcinos autofluorescen durante la gestación porcina temprana en los períodos gestacionales seleccionados en esta tesis, lo que coincide con lo reportado por Keys y col (1989). Por ello se decidió realizar las experiencias a través de una técnica de inmunohistoquímica directa empleando peroxidasa (HRP: horse radish peroxidase).

Para el dosaje de las concentraciones de IgG se emplearon dos técnicas, porque no encontramos información acerca de los valores esperables durante la gestación porcina. Hallamos resultados dispares entre ellas; si bien la inmunoturbidimetría es una técnica sensible que se utiliza para determinar IgG en suero, en medicina humana, los valores que obtuvimos en cerdas siempre fueron menores a los obtenidos por IDR.

No encontramos diferencias significativas en las concentraciones séricas de proteínas totales durante la preñez porcina, ya que se mantuvieron en rangos fisiológicos normales. Se supone que si aumentan, en general, es por incremento de la síntesis de globulinas; y, la elevación de las globulinas se observa en estados de respuesta contra agentes infecciosos, en procesos inflamatorios crónicos, en enfermedades inmunomediadas, en cáncer o luego de vacunaciones (Tizard, 2009). Se sabe que la madre mantiene la habilidad de resistir infecciones durante la gestación (Wooding y Burton, 2008), por lo que nuestros resultados demostrarían que la respuesta 
inmune humoral no se modifica cuantitativamente de manera ostensible durante la gestación porcina.

Tampoco encontramos diferencias en las concentraciones de albúmina entre los diferentes períodos gestacionales estudiados; lo cual refleja que el equilibrio osmótico se mantiene durante la preñez porcina, dado que la albúmina es la proteína más abundante (representa en porcinos alrededor del $50 \%$ ) en el plasma (Cunningham y Klein, 2009).

La IgG es una de las cinco clases de anticuerpos producidos por el cerdo, constituye la proteína mayoritaria, alrededor del $80-85 \%$, de las globulinas en suero (Butler y col., 2005; Butler y col., 2009b; Sánchez Vizcaíno, 2010) y es, en número, el efector humoral predominante que desempeña la función de anticuerpo. Toda respuesta inmune que cursa con producción de anticuerpos del isotipo IgG precipitantes, fijadores de complemento, depuradores de Antígenos, está acompañada por otra población de anticuerpos, denominados Ac IgG asimétricos, también del isotipo IgG con los mismos subtipos que los precipitantes pero que poseen un comportamiento inmunoquímico y biológico diferente (Margni, 1989).

En nuestro trabajo no encontramos diferencias significativas en el porcentaje de Ac $\operatorname{IgG}$ asimétricos, en suero, entre cerdas vacías y preñadas. Pero sí hallamos diferencias en el porcentaje de Ac IgG asimétricos entre los diferentes períodos de gestación estudiados; sin embargo, esas diferencias no modificaron significativamente la concentración de proteínas totales ni de albúmina, sólo se registró en la fracción de las globulinas. Esa diferencia en el porcentaje de Ac IgG simétricos y asimétricos hallada en suero entre los distintos períodos gestacionales, podría ser uno de los factores que regulan la respuesta inmune materna. 
Así, solo a los 30 días de preñez, encontramos una disminución de Ac IgG asimétricos en sueros, mientras que, al final de la preñez, en el período de 95-114 días, hallamos un aumento. Probablemente la disminución sérica de Ac IgG asimétricos al inicio de la gestación se deba al pasaje de dichos Ac a la interfase feto materna, a fin de preservar el aloinjerto fetal. Mientras que, el aumento de Ac IgG asimétricos séricos al final de la preñez reflejaría un mecanismo de compensación a fin de subsanar la caída brusca de la concentración de IgG en suero, que se produce cuando la mayoría de las IgG se concentran en las glándulas mamarias a fin de formar parte del calostro (Watson, 1980; Wagstrom y col., 2000). Además, cuando determinamos las concentraciones de IgG séricas mediante Inmunodifusión radial e Inmunoturbidimetría, técnicas que no discriminan entre Ac IgG simétricos y asimétricos, encontramos un brusco descenso de IgG hacia el final de la gestación; probablemente porque las IgG que formarán parte del calostro pertenezcan al tipo de Ac IgG simétricos, funcionales biológicamente, a fin de brindar protección inmediata al neonato contra los microorganismos ambientales.

Estudios previos en humanos determinaron que durante el primer trimestre de la gestación los niveles de IgG en suero fetal estaban muy bajos, aumentando durante el segundo trimestre a valores aproximados de un 5 a un $10 \%$ de los valores maternos, mientras que al finalizar la gestación los valores de $\operatorname{IgG}$ fetales superaban a los valores maternos alcanzando niveles de $11,98 \pm 2,18 \mathrm{~g} / 1$. Mientras que la concentración de $\operatorname{IgG}$ en suero materno al término de la gestación disminuye a niveles de 60 a $70 \%$ de la concentración que se observaba al principio de la preñez (Li y col., 2014). 
Fue difícil de correlacionar las concentraciones de IgG dosadas mediante Inmunoturbidimetría en suero con los valores de Ac IgG asimétricos, ya que encontramos valores muy bajos en comparación a los detectados mediante Inmunodifusión radial; tampoco hallamos diferencias, con la técnica de Inmunoturbidimetría en las concentraciones de $\operatorname{IgG}$ entre los períodos gestacionales y en lo único en que concuerdan las dos técnicas es en que detectamos diferencias entre cerdas vacías y preñadas, con una disminución de $\operatorname{IgG}$ al final de la preñez.

Con respecto a la determinación de proteínas totales en los homogenatos placentarios maternos, los valores encontrados se corresponden con los hallados anteriormente en nuestro laboratorio (Koncurat y col., 2003b). La técnica de obtención de estos homogenatos consistió en una ruptura mecánica grosera del tejido placentario, una centrifugación para eliminar los restos de tejido y por último una filtración de los sobrenadantes obtenidos para poder dosar las proteínas solubles liberadas por la lisis celular, lo cual explicaría la baja concentración de proteínas halladas. De todas maneras se hallaron diferencias significativas en las concentraciones de proteínas totales en los homogenatos placentarios maternos en los distintos períodos gestacionales estudiados, particularmente aumentaron las proteínas totales a los 65-70 días de preñez, lo que coincide con el aumento registrado de Ac asimétricos en ese período y que reflejaría el requerimiento de proteínas por el tejido placentario materno, particularmente de $\operatorname{IgG}$, a mediados de la gestación.

En trabajos previos hallamos que, hasta alrededor de los 60 días de preñez, el crecimiento del embrión (determinado mediante el peso expresado en g) es lineal, para luego adoptar una función de tipo potencial (Zubeldía, 2007); lo que concuerda con estudios realizados por Merkis $y$ col., 2006, quienes señalan que a partir de ese período, en cerdas mestizas de nuestra región, se 
evidencia un marcado desarrollo de vasos de mayor calibre que se acompaña con un aumento de las arborizaciones de las interdigitaciones placentarias, lo que redundaría en una mayor eficiencia del transporte de nutrientes, y a consecuencia de ello el feto podría aumentar su masa en forma potencial.

Entonces, el aumento de Ac IgG asimétricos que se registró a los 65-70 días de preñez en los homogenatos de placenta materna, coincide con el período en que la placenta deja de aumentar en peso y volumen y alcanza su meseta de crecimiento durante la preñez porcina (Wilson and Ford, 2001; Merkis y col., 2005; Bazer y Johnson, 2014), lo que nos hace pensar que las IgG sintetizadas por la madre se concentran en la placenta materna, particularmente en la interfase feto materna, a fin de proteger al feto del sistema inmunológico materno. Porque si bien la placenta no aumenta en peso y volumen, sí continúa la remodelación celular de su estructura, particularmente de las vellosidades que conforman la interfase a través de mecanismos apoptóticos (Cristofolini, 2010; Merkis y col., 2010), por lo cual sería necesaria la presencia de IgG en las nuevas células expuestas en la interfase para impedir el rechazo. El porcentaje de Ac IgG asimétricos desciende significativamente a término en los homogenatos de placenta materna porque las $\operatorname{IgG}$ maternas se concentran en las glándulas mamarias.

No hallamos diferencias en la concentración de proteínas totales entre cerdas vacías (homogenatos de útero vacío) y preñadas (homogenatos de placenta materna). Tampoco encontramos en dichos homogenatos variaciones en la concentración de IgG determinada mediante Inmunodifusión radial, aunque llama la atención la alta concentración de IgG determinada por esta técnica en los extractos maternos. Por el contrario, cuando determinamos concentraciones de IgG mediante Inmunoturbidimetría, si bien no encontramos diferencias entre 
los períodos gestacionales, si hallamos diferencias entre los homogenatos de útero de cerdas vacías y los homogenatos de placenta materna, detectando los valores más altos de IgG en cerdas vacías, probablemente porque las IgG dosadas hayan sido Ac simétricos que podrían mediar el rechazo.

Con respecto a los homogenatos de placenta fetal, llama la atención el alto porcentaje de Ac IgG asimétricos determinados en esos extractos en todos los períodos gestacionales estudiados, dado que el feto recién comienza a sintetizar sus primeros Ac a partir de los 50 días de preñez (Šinkora y col., 2003; Rothkötter, 2009; Butler y col., 2009a). Por lo tanto postulamos que estos Ac deben haber sido producidos por la madre.

No se hallaron diferencias en la concentración de proteínas totales entre los homogenatos de útero de cerda vacía y los homogenatos fetales de cerdas preñadas, pero sí entre los períodos gestacionales, encontrando un aumento significativo a los 30 días y una disminución de proteínas totales a los 65-70 días de preñez. Se sabe que al inicio de la gestación la placenta fetal crece en forma exponencial, a fin de brindar el soporte estructural a la implantación de los embriones/fetos para lo cual requiere de proteínas, y que, al igual que la placenta materna, sufre cambios morfológicos que permiten el desarrollo del feto manteniendo la continuidad estructural de la interfase feto materna. Nosotros encontramos hacia los 65-70 días de gestación que se produce una disminución notoria de proteínas totales en la placenta fetal y un aumento significativo en la placenta materna, por lo que las mayores remodelaciones placentarias en este período estarían a cargo de la placenta materna. Pero, a pesar de la disminución notoria de proteínas totales en este período en los homogenatos de placenta fetal, no encontramos diferencias significativas en el porcentaje de Ac IgG asimétricos entre los distintos períodos gestacionales, por el contrario los Ac 
IgG asimétricos se mantienen elevados durante toda la gestación en placenta fetal; tampoco encontramos diferencias en las concentraciones de $\operatorname{IgG}$ dosadas por las dos técnicas en este período, por lo que especulamos que la disminución de proteínas totales observada en los homogenatos de placenta fetal no se realiza a expensas de las IgG y que, además, las IgG presentes en la placenta fetal podrían ser Ac Ig G asimétricos, de origen materno, necesarios en la interfase a fin de proteger al aloinjerto fetal.

Según nuestro conocimiento, nuestros trabajos fueron los primeros en demostrar anticuerpos asimétricos en cerdos y, particularmente, en la gestación porcina (Gentile y col., 2004).

Para Gutiérrez y col., 2001, quienes trabajaron en ratones, los anticuerpos IgG asimétricos glicosilados y funcionalmente univalentes influyen en el balance entre la madre y los fetos, desempeñando un papel importante en la sobrevida fetal en el claustro materno. Varios autores (Margni y Malan Borel, 1998; Zenclussen y col., 2001; Canellada y col., 2002) han detectado un aumento de Ac asimétricos en suero al final de la preñez, en gestaciones humanas y murinas. Por el contrario, nosotros no observamos diferencias significativas en el porcentaje de Ac IgG asimétricos en el suero entre cerdas vacías y preñadas, pero sí detectamos diferencias entre los períodos gestacionales, los Ac asimétricos disminuyen a los 30 días de preñez y aumentan al final de la preñez, probablemente esto se deba al tipo diferente de placentas, ya que la cerda posee una placenta epiteliocorial y no invasiva que modularía el traspaso de las IgG, tanto simétricas como asimétricas.

Actualmente, Gu y col., 2015, demostraron que la placenta humana puede producir $\operatorname{IgG}$ glicosiladas en uno solo de sus fragmentos Fab (Ac IgG asimétricos), proponiendo que dichas 
IgG interactúan con otros Ac y ciertos leucocitos para direccionar la respuesta inmune local y permitir la unión entre dos entidades genéticamente diferentes.

Cuando comparamos los valores de Ac IgG asimétricos obtenidos en todas las muestras dosadas, ya sea de suero, homogenato de placenta fetal u homogenato de placenta materna, encontramos los valores más bajos de Ac IgG asimétricos en los homogenatos de placenta, excepto en el período 65-70 días de gestación.

Es de suponer que las IgG halladas en los extractos placentarios fetales y maternos son mayoritariamente del tipo de IgG asimétricas para proteger al aloinjerto fetal, porque si se tratara de IgG simétricas desencadenarían la destrucción de los tejidos. Por lo tanto, hipotetizamos que la mayoría de las IgG detectadas serían Ac IgG asimétricos sintetizados por los linfocitos B de la madre y que existiría un tipo especial de transporte a través del epitelio uterino luminal hacia la placenta fetal, tal como acontece a partir de los 92-95 días de preñez cuando las IgG se concentran en las glándulas mamarias (Huang y col., 1992; Salmon y col., 2009).

Solamente en los extractos placentarios fetales se hallaron valores altos de Ac IgG asimétricos, los que se mantienen constantes durante toda la preñez y son detectados a partir de 30 días de preñez.

Actualmente, en estudios realizados en placentas humanas encontraron que un porcentaje de los Ac IgG estaban glicosilados en solo uno de los fragmentos Fab de la molécula. Postulan que dichos Ac IgG asimétricos podrían reaccionar con las células inmunes y otros Ac para favorecer la evasión del sistema inmune materno en la placenta (Li y col., 2014). 
A partir de nuestros resultados postulamos que un mecanismo a través del cual la cerda protege a sus embriones/fetos es por transcitosis de las IgG (Dickinson y col., 1999); Stirling $y$ col., 2005), la que se realizaría a través de la placenta materna. Creemos que las IgG quedan atrapadas en la interfase feto materna, en el espacio existente entre en el epitelio uterino gestante (vellosidades de la placenta materna) y las células epiteliales trofoblásticas, las que, junto con el corion, forman la placenta fetal. Este mecanismo explicaría la presencia de las IgG que nosotros observamos mediante IHQ en cortes histológicos de placenta fetal en individuos que aún no tienen la capacidad de sintetizar moléculas de IgG.

Para que las IgG puedan trasladarse a través de los tejidos es necesario que se encuentren unidas a su receptor, especialmente al FcRn. Está demostrado que los FcRn se encuentran presentes en los tejidos (Stirling y col., 2005; Ye y col., 2008). Nosotros detectamos expresión positiva del receptor Fe de las $\operatorname{IgG}$ en los cortes histológicos de placentas tanto maternas como fetales, a los 30 días de preñez. Sólo la presencia del FcRn permite la transcitosis de las IgG a través de los epitelios y este mecanismo nos permite explicar la presencia de IgG detectada por inmunohistoquímica sobre cortes histológicos, en períodos en los cuales el feto aún no posee la capacidad de sintetizar IgG. Lo expuesto concordaría con lo postulado por Li y col., 2014, quienes determinaron que en la especie humana se producirían dos mecanismos moleculares diferentes luego de la internalización de la IgG en las células del sincitiotrofoblasto, uno de ellos permitiría el transporte de la IgG a la sangre fetal unida a su FcRn y el segundo mecanismo molecular que se produce en el citoplasma permitiría que las IgG glicosiladas producidas por la placenta forme complejos inmunes con los anticuerpos anti- $\mathrm{MCH}$ paternos y fetales, bloqueando su acción, constituyendo un mecanismos de evasión inmune de la placenta impidiendo que los 
anticuerpos maternos puedan cruzar la barrera placentaria e indirectamente protegiendo al feto del rechazo inmune.

Concluimos que durante la preñez porcina, la presencia de moléculas de IgG y de su receptor Fc en la interfase feto materna desde los 30 días de gestación, particularmente las IgG asimétricas que llegarían por transcitosis desde el epitelio materno, cumplirían un rol de protección inmunológica del feto, por lo que se destaca el papel que desempeña el sistema inmune humoral en la gestación porcina. 


\section{CONCLUSIONES}

- Se describe por primera vez el hallazgo de anticuerpos asimétricos de la clase IgG en porcinos.

- No se hallaron diferencias significativas en la concentración de Ac IgG asimétricos en suero entre cerdas preñadas en diferentes períodos gestacionales y cerdas vacías, dado el tipo de placenta no invasiva y epiteliocorial que presenta la cerda.

- Se hallaron diferencias significativas en la concentración de anticuerpos asimétricos en suero entre cerdas preñadas de 30 días de gestación y cerdas de 95 días de gestación.

- En homogenatos de placenta materna se encontró solo a los 65-70 días de preñez alta concentración de Ac IgG asimétricos.

- En homogenatos de placenta materna se encontró una disminución marcada de la concentración de Ac IgG asimétricos a los 95-114 días.

- Únicamente en los homogenatos de placenta fetal se hallaron valores altos de Ac IgG asimétricos a concentraciones constantes durante toda la preñez.

- Se detectó la expresión de las IgG a partir de los 30 días de preñez sobre cortes histológicos de placenta materna y fetal.

- Se detectó la expresión del receptor Fe de la IgG a partir de los 30 días de preñez sobre cortes histológicos de placenta materna y fetal.

- Se postula que las IgG que se detectan en los cortes histológicos de placenta materna y fetal serían de origen materno y que por transcitosis alcanzaron la interfase feto materna.

- Se postula que la respuesta inmune humoral que se instala durante la gestación, efectivizada por los anticuerpos IgG asimétricos, protege al embrión/feto del reconocimiento materno 
ante la exposición de sus antígenos considerados como no propios por la hembra gestante, lo cual permite una gestación exitosa en porcinos. 


\section{BIBLIOGRAFÍA}

1. Amoroso EC. Placentation. Autor: Marshall FHA. En: Marshall's Physiology of Reproduction. 3ra Edición. Longmans Green, Londres, Ed. Parkes AS, 1952, Vol 2, p. 127-331.

2. Akilesh S, Christianson G, Roopenian D, Shaw A. Neonatal FcR expression in bone marrow-derived cells functions to protect serum IgG from catabolism. J Immunol. 2007; 179:4580-88.

3. Apicella C, Rey Roldan E, Chiappetta DA, Molinari C, Bregni C, Dokmetjian J, Gentile MT. Asymmetric IgG antibodies induced by different immunotherapies in a murine model of allergy. Immunol Invest. 2009; 38:572-88.

4. Barañao RI. Inmunología de la gestación. Reproducción. 2010; 25:168-84.

5. Bazer FW, Johnson GA. Pig blastocyst-uternine interactions. Differentiation. 2014; $87: 52-65$

6. Bazer FW, Spencer TE, Johnson GA. Interferons and uterine receptivity. Semin Reprod Med. 2009a; 27:90-102.

7. Bazer FW, Spencer TE, Johnson GA, Burghardt WG. Comparative aspects of implantation. Reproduction. 2009b; 138:195-209.

8. Bazer FW, Thatcher WW. Theory of maternal recognition of pregnancy in swine based on estrogen controlled endocrine versus exocrine secretion of prostaglandin F2 $\alpha$ by the uterine endometrium. Prostaglandins. 1977; 14:111-29.

9. Bazer FW, Wu G, Johnson GA, Wang X. Environmental factors affecting pregnancy: Endocrine disrupters, nutrients and metabolic pathways. Mol Cell Endocrinol. 2014; Article in press. 
10. Blomberg L, Hashizume K, Viebahn C. Blastocyst elongation, trophoblastic differentiation, and embryonic pattern formation. Reproduction. 2008; 135:181-95.

11. Bosch RA, Alanis GA, Allende RA, Blanch MS, Bosch P, Callejas S. Mortalidad embrionaria basal en las especies domésticas de interés productivo. En: Actualización en temas de reproducción animal. 1ra Edición. Compilador, Bosch RA. Ed. Universidad Nacional de Río Cuarto. Río Cuarto. 2001; p. 150-52.

12. Bowen JA, Bazer FW, Burghardt RC. Spatial and temporal analyses of integrin and muc1 expression in porcine uterine epithelium and trophoectoderm in vivo. Biol Reprod. 1996; 55:1098-106.

13. Brunori J. Producción de cerdos en la Argentina. Situación, oportunidades y desafíos. INTA Marcos Juarez. [Online]. [Citado el 5 de Noviembre de 2014]. Disponible desde: http://www.aapa.org.ar/congresos/2011/

14. Burton GJ, Waston AL, Hempstock J, Skepper J, Jauniaux E. Uterine glands provide histiotrophic nutrition for the human fetus during the first trimester of pregnancy. J Clin Endocrinol Metab. 2002; 15:2954-59.

15. Butler JE, Howard C. Summary of the comparative immunoglobulin workshop (CIgW) on immunoglobulins (Igs) and Fc receptors. Vet Immunol Immunopathol. 2002; 87:48184.

16. Butler JE, Lager KM, Splichal I, Francis D, Kacskovics I, Šinkora M, Wertz N, Sun J, Zhao Y, Brown WR, DeWald R, Dierks S, Muyldermans S, Lunney JK, McCray PB, Rogers CS, Welsh MJ, Navarro P, Klobasa F, Habe F, Ramsoondar J. The piglet as a 
model for B cell and immune system development. Vet Immunol Immunopathol. 2009a; 128:147-70.

17. Butler JE, Šinkora M, Wertz N, Holtmeier W, Lemke C. Development of the neonatal B and $\mathrm{T}$ cell repertoire in swine: implications for comparative and veterinary immunology. Vet Res. 2006a; 37:417-41.

18. Butler JE, Sun J, Werts N, Šinkora M. Antibody repertoire development in swine. Dev Comp Immunol. 2006b, 30:199-221.

19. Butler JE, Weber P, Šinkora M, Sun J, Ford SJ, Christenson R. Antibody repertoire development in fetal and neonatal piglets. II. Characterization of heavy chain CDR3 diversity in the developing fetus. J Immunol. 2000; 165:6999-7011.

20. Butler JE, Wertz N. The porcine antibody repertoire: variations on the textbook theme. Front Immunol. 2012; 3:153.

21. Butler JE, Wertz N, Deschacht N, Kacskovics I. Porcine IgG: structure, genetics, and evolution. Immunogenetics. 2009b; 61:209-30.

22. Butler JE, Wertz N, Sun J, Wang H, Lemke C, Chardon P, Puimi F, Wells K. The preimmune variable kappa repertoire of swine is selectively generated from certain subfamilies of Vk2 and one Jk gene. Vet Immunol Immunopathol. 2005; 108:127-37.

23. Butler JE, Zhao Y, Šinkora M, Wertz N, Kacskovics I. Immunoglobulins, antibody repertoire and B cell development. Dev Comp Immunol. 2008; 33:321-33.

24. Canellada A, Alvarez I, Berod L, Gentile MT. Estrogen and progesterone regulate the IL6 signal transduction pathway in antibody secreting cells. J Biochem Mol. 2008; 111:25561. 
25. Canellada A, Gentile MT, Dokmetjian J, Margni RA. Occurrence, properties, and function of asymmetric IgG molecules isolated from non-immune sera. Immunol Invest. 2002; $31: 107-20$.

26. Cervenak J, Kacskovics I. The neonatal Fc Receptor plays a crucial role in the metabolism of IgG in livestock animals. Vet Immunol Immunophatol. 2009; 128:1-3.

27. Chen SJ, Liu YL, Sytwu HK. Immunologic regulation in pregnancy: from mechanism to therapeutic strategy for immunomodulation. Clin Dev Immunol. 2012; Article ID 258391, 10 pages doi:10.1155/2012/2583912012:258391.

28. Cortés M, Canellada A, Miranda S, Dokmetjian J, Gentile MT. Placental secreted factors: their role in the regulation of anti- $\mathrm{CH}$ antibodies and amelioration of collagen induced arthritis in rats. Immunol Lett. 2008; 119:42-48.

29. Cristofolini AL. Estudio de la remodelación celular durante la placentación porcina. Tesis doctoral. Facultad de Agronomía y Veterinaria, Universidad Nacional de Río Cuarto. 2010.

30. Croy BA, Wessels J, Linton N, Tayade C. Comparison of immune cell recruitment and function in endometrium during development of epitheliochorial (pig) and hemochorial (mouse and human) placentas. Placenta. 2009; 23:526-31.

31. Cunningham JG, Klein BG. En: Fisiología Veterinaria. 4ta Edición. Barcelona, España, Ed. Elsevier, 2009, p. 13-33.

32. Dantzer V. Electron microscopy of the initial stages of placentation in the pig. Anat Embryol. 1985; 172:281-93.

33. Dantzer V, Bjorkman N. Placentación. En: Dellman, D. Histología Veterinaria. 2 da Edición. Zaragoza, España, Ed. Acribia, 1994, p. 291-306. 
34. Dantzer V, Leiser R. Microvascularization of regular and irregular areolae of the areolagland subunit of the porcine placenta: structural and functional aspects. Anat Embryol. 1993a; 188:257-67.

35. Dantzer V, Leiser R. Initial vascularization in the pig placenta. I. Demostration of nonglandular areas by histology and corrosion casts. Anat Rec. 1993b; 238:177-90.

36. Dickinson BL, Badizadegan K, Wu Z, Ahouse JC, Zhu X, Simister NE, Blumberg RS, Lencer WI. Bidirectional FcRn-dependent IgG transport in a polarized human intestinal epithelial cell line. J Clin Invest. 1999; 104:903-11.

37 Dimova T, Mihaylova A, Spassova P, Georgieva R. Establisment of the porcine epitheliochorial placenta is associated with endometrial T-Cell recruitment. J Reprod Immunol. $2007 ; 57: 250-61$.

38. Di Rienzo JA, Casanoves F, Balzarini MG, Gonzales L, Tablada EM, Robledo CW. InfoStat. Grupo InfoStat. Facultad de Ciencias Agrarias. Universidad Nacional de Córdoba. 2011.

39. Dubinsky V, Junovich G, Gentile MT, Gutiérrez G. IL 6 as a regulatory factor of the humoral response during pregnancy. Am J Reprod Immunol. 2008; 60:197-203.

40. Edwards AK, Wessels JM, Kerr A, Tayade C. An overview of molecular and cellular mechanisms associated with porcine pregnancy success or failure. Reprod Dom Anim. $2012 ; 47: 394-401$.

41. Eguchi-Ogawa T, Wertz N, Sun X, Puimi F, Uenishi U, Wells K, Chardon P, Tobin G, Butler J. Antibody repertoire development in fetal and neonatal piglets. XI. The relationship of variable heavy chain gene usage and the genomic organization of the variable heavy chain locus. J Immunol. 2010; 184:3734-42. 
42. Engelhardt H, Croy BA, King GJ. Evaluation of natural killer cell recruitment to embryonic attachment sites during early porcine pregnancy. Biol Reprod. 2002a; 66:1185-92.

43. Engelhardt H, Croy BA, King GJ. Conceptus influences the distribution of uterine leukocytes during early porcine pregnancy. Biol Reprod. 2002b; 66:1875-80.

44. Engelhardt H, King GJ. Uterine natural killer cells in species with epitheliochorial placentation. Nat Immunol. 1996; 15:115-31.

45. Escobar Medina F. Tamaño de la camada de la cerda. Veterinaria Zacatecas. Publicación de la Unidad Académica de Medicina Veterinaria y Zootecnica. Universidad Autónoma de Zacatecas, Mexico. 2004; 2:137-46.

46. Franczak A, Kotwica G. Secretion of estradiol-17 $\beta$ by porcine endometrium and myometrium during early pregnancy and luteolysis. Theriogenology. 2008; 69:283-89.

47. García S. El Mercado de carne de cerdo en Argentina y en el mundo. Fericerdo, Ed INTA E.E.A. Marcos Juárez. Asociación Argentina de Productores de Porcinos 2007; 1-6 [Online]http://www.produccion-animal.com.ar/produccion_porcina/00-carne_porcina/75mercado.pdf Martes/ Sofía Garcia.pdf

48. Garro AC, Gentile MT, De León R, Koncurat MA. Inmunoglobulinas G asimétricas en sueros y extractos placentarios maternos porcinos. IV Jornadas Asociación Argentina de Inmunología Veterinaria, Río Cuarto, Córdoba, Argentina. 2011, p. 80.

49. Garro AC, Gómez B, Alonso G, Hernández M y Koncurat M. IgG and Fc receptor in porcine placenta. III Latin - American Symposium on Maternal - Fetal Interaction and placenta: Basic \& Clinical Research. Los Cocos, Córdoba, Argentina, 2007, p. 89-90. 
50 Geneser F. Órganos de la reproducción. En: Histología. 3ra Edición. Madrid, España, Ed. Panamericana SA, 2008, p. 663-74.

51. Gentile MT, Llambias P, Dokmetjian J, Margni RA. Effect of pregnancy and placental factors on the quality of humoral immune response. Immunol Lett. 1998; 62:151-57.

52. Gentile MT, Margni R, Williamson DM, Garro AC, Alonso G, Bruni M, Riesco O, Yaful GN y Koncurat MA. Presencia de IgG asimétricos en sueros porcinos. Estudio preliminar. Jornada de Ciencia y Técnica, Facultad de Ciencias Veterinarias, Universidad Nacional de La Pampa, 2004.

53. Ghetie V, Sally Ward E. Multiple roles for the major histocompatibility complex class Irelated receptor FcRn. Annu Rev Immunol. 2000; 18:739-66.

54. Gómez Esperanza L, Blanco M, Domenech A. Inmunidad en el feto y en neonato. En: Manual de Inmunología Veterinaria. 1 Edición. Madrid, España, Ed. Prentice Hall Pearson, 2007, p. 492-97.

55. Gray C, Bartol F, Tarleton B, Wiley A, Johnson G, Bazer F, Spencer T. Developmental biology of uterine glands. Biol Reprod. 2001; 65:1311-23.

56. Gu J, Lei Y, Huang Y, Zhao Y, Li J, Huang T, Zhang J, Wang J, Deng X, Chen Z, Korteweg C, Deng R, Yan M, Xu Q, Dong S, Cai M, Luo L, Huang G, Wang Y, Li Q, Lin C, Su M, Yang C, Zhuang Z. Fab fragment glycosylated IgG may play a central role in placenta immune evasion. Hum Reprod. 2015; 30:380-91.

57. Gutiérrez G, Junovich G, Dubinsky V, Pasqualini RS, Gentile MT. El rol de la interleuquina 6 en el éxito gestacional. SAEGRE. 2008; 15:43-47. 
58. Gutiérrez G, Malal Borel I, Margni RA. The placental regulatory factor involved in the asymmetric IgG antibody synthesis responds to IL-6 features. J Reprod Immunol. 2001; 49:21-32.

59. Hafez ESE, Hafez B. En: Reproducción e inseminación artificial en animales. Hafez ESE, Hafez B. 7ma Edición. México, Ed. McGraw-Hill Interamericana, 2003, p. 85.

60. Huang SC, Hu ZI, Hasler-Rapaez J, Rapaez J. Preferential mammary storage and secretion of immunoglobulin gama (IgG) subclasses in swine. J Reprod Immunol. 1992; 21:1528.

61. Johansson S, Dencker L, Dantzer V. Immunohistochemical localization of retinol binding proteins at the materno - fetal interface of the porcine epitheliochorial placenta. Biol Reprod. $2001 ; 64: 60-68$.

62. Jones CJP, Dantzer V, Leiser R, Krebs C, Stoddart RW. Localisation of glycans in the placenta: a comparative study of epitheliochorial, endotheliochorial, and haemomonochorial placentation. Microsc Res and Tech. 1997; 38:100-114.

63. Jones CJP, Wooding FBP, Abd-Elnaeim, Leiser R, Dantzer V, Stoddart RW. Glycosylation in the near-term epitheliochorial placenta of the horse, donkey and camel: comparative study of interbreeding and non-interbreeding species. J Reprod Fert. 2000; 118:397405.

64. Joyce MM, Burghardt JR, Burghardt RC, Hooper RN, Bazer FW, Johnson GA. Uterine MHC class I molecules and beta 2-microglobulin are regulated by progesterone and conceptus interferons during pig pregnancy. J Immunol. 2008; 181(4):2494-505.

65. Joyce MM, Burghardt RC, Geiser RD, Burghardt JR, Hooper RN, Ross JW, Ashworth MD, Johnson GA. Pig conceptus secrete estrogen and interferons to differentially regulate 
uterine STAT 1 in a temporal and cell-type specific manner. Endocrinology. 2007; $148: 4420-431$

66. Ka H, Al Ramadan S, Erikson DW, Johnson GA, Burghardt RC, Spencer TE, Jaeger LA, Bazer FW. Regulation of expression of fibroblast growth factor 7 in the pig uterus by progesterone and estradiol. Biol Reprod. 2007; 77:172-80.

67. Kacskovics I. Fc receptors in livestock species. Vet Immunol Immunopathol. 2004; 102:351-62.

68. Kacskovics I, Cervenak J, Erdei A, Goldsby RA, Butler JE. Recent advances using FcRn overexpression in transgenic animals to overcome impediments of standard antibody technologies to improve the generation of specific antibodies. Landes Bioscience. 2011; 89:431-439.

69. Kelemen K, Bognar I, Paal M, Szekeres-Bartho J. A progesterone-induced protein increases the synthesis of asymmetric antibodies. Cell Immunol. 1996; 167:129-34.

70. Keys JL, King GJ, Laforest JP. Autofluorescence of the porcine endometrium during early pregnancy. Biol Reprod. 1989; 40:220-22.

71. Koncurat MA. Estudio inmunoendocrino de la preñez porcina. Papel de la placenta. Tesis doctoral. Facultad de Agronomía y Veterinaria, Universidad Nacional de Río Cuarto. 2003a.

72. Koncurat MA, Riesco OF, Garro AC, Yaful GN, Lacolla DV, Bruni MA, Williamson DM. Detección de inmunoglobulina $\mathrm{G}$ en sueros, tejidos y extractos placentarios porcinos. Ciencia Veterinaria. 2003b; 5:1-9. 
73. Koncurat MA, Merkis C, Zubeldía D, Chanique A, Cristofolini A, Franchino M, Abate Cano L, Sanchis G, Falco P, Vivas A. Detection of glycoconjugates in the placenta porcine in different gestational periods. Int J Morphol. 2004; 22(1):35-36.

74. Koncurat MA, Riesco OF, Vélez C, Williamson DM. Determinación de la concentración de IL-18, IL-15, IL-12, IL-6 e IFNr en homogenatos placentarios maternos, fetales y suero a través de la gestación porcina. XXII Reunión Latinoamericana de Producción Animal, 2011, Montevideo, Uruguay.

75. Li J, Korteweg C, Qiu Y, Luo j, Chen Z, Huang G, Li W, Gu J. Two ultrastructural distribution patterns of immunoglobulin $\mathrm{G}$ in human placenta and functional implications. Biol Reprod. 2014: Papers in press.

76. Malan Borel I, Gentile MT, Angelucci J, Pividori J, Guala MC, Binaghi RA, Margni RA. IgG asymmetric molecules with antipaternal activity isolated from sera and placenta of pregnant human. J Reprod Immunol. 1991; 20:129-40.

77. Male D, Brostoff J, Roth D, Roitt IM. Anticuerpos. En: Inmunología. Fundamentos. 7ma Edición. España, Madrid, Ed. Panamericana SA, 2007, p. 59-78.

78. Margni RA. Anticuerpos IgG asimétricos. Estudios estructurales, inmunoquímicos y biológicos. Medicina. 1989; 49:147-54.

79. Margni RA, Binaghi RA. Purification and properties of non-precipitating rabbit antibodies. Immunology. 1972; 22:57-63.

80. Margni RA, Malan Borel I. Paradoxical behavior of asymmetric IgG antibodies. Immunol Rev. 1998; 163:77-87. 
81. Margni RA, Malan Borel I. Role of asymmetric IgG in fetal maintenance. Curr Trends Immunol. 1999; 2:153-63.

82. Marrable AW. En: The embryonic pig: a chronological account. Great Britain, Ed. Exeter, Pitman Medical Publishing, 1971, p. 30-51.

83. McConico A, Butters K, Lien K, Knudsen B, Wu X, Platt J, Ogle B. In utero cell transfer between porcine littermates. Reprod Fertil Dev. 2011; 23:297-302.

84. Merkis CI, Cristofolini AL, Franchino M, Moschetti E, Koncurat MA. Relación entre área total y área epitelial de vellosidades placentarias porcinas en diferentes estadíos gestacionales. InVet. 2005; 7:47-54.

85. Merkis CI, Cristofolini A, Franchino M, Sanchis E, Moschetti E, Koncurat MA. Angiogénesis placentaria durante la gestación porcina. Red Vet. 2006; 7:1-4. [Online] http://www.veterinaria.org/revistas/redvet

86. Merkis CI, Cristofolini A, Sanchis E, Koncurat M. Expression of death cellular receptors FAS/CD95 during porcine placentation. Int J Morphol. 2010; 28:829-34.

87. Ministerio de Agricultura, Ganadería y Pesca. Diciembre 2011. Anuario 2011, Porcinos, p. 22. [Online] http://www.minagri.gob.ar

88. Ministerio de Agricultura, Ganadería y Pesca. Noviembre 2014. Anuario 2013, Porcinos, [Online] http://www.minagri.gob.ar

89. Ministerio de Agricultura, Ganadería y Pesca (Minagri). Dirección de Ovinos, Porcinos, Aves de Granja y Pequeños Rumiantes - DNPG. Informe porcinos Nº 4. Junio 2012. [Online] http://www.minagri.gob.ar

90. Ministerio de la Producción de la Provincia de La Pampa, Estadística y Censos, noviembre 2014. http://www.estadisticalapampa.gov.ar/ 
91. Mostov KE. Transepithelial transport of immunoglobulins. Annu Rev Immunol. 1994; 12: 63-84.

92. Paños Adillo G. Receptores porcinos celulares. Aplicación como marcadores biológicos. Tesis doctoral. Universidad Nacional de Córdoba, España. 2003.

93. Pennimpede EF, Gómez CM, Stanchi NO. Introducción a la Inmunobiología. 1 ed. Ed. de la UNLP. La Plata, Argentina, 2004, p. 303-17.

94. Perry JS. The mammalian fetal membranes. J Reprod Fertil. 1981; 62:321-35.

95. Pope WF. Embrionic mortality in swine. En: Embrionic mortality in domestic species. Ed. Zavy MT and Geisert RD. Boca Ratón, Fl, Estados Unidos, 1994, p. 53-77.

96. Pope WF, Wilde M, Xie S. Effects of electrocautery of nonovulated day 1 follicles on subsequent morphological variation among day 11 porcine embryos. Biol Reprod. 1988; 39:882-87.

97. Rabinovich AG. Inmunobiología del embarazo: mecanismos celulares y moleculares involucrados en el mantenimiento de la unidad maternofetal. Inmunopatología Molecular: Nuevas Fronteras de la Medicina. 1ra Edición. Madrid, España, Ed. Panamericana SA, 2004, p.352-58.

98. Raghavan M, Bjorkman P. Fc receptors and their interactions with immunoglobulins. Cell Dev Biol. 1996; 12:181-220.

99. Ramsoondar JJ, Christopherson RJ, Guilbert LL, Dixon WT, Ghahary A, Ellis S, Wegmann TG, Piedrahita JA. Lack of class I major histocompatibility antigens on trophoblast of periimplantation blastocyst and term placenta in the pig. Biol Reprod. 1999; 60:387-97. 
100. Rothkötter H. Anatomical particularities of the porcine immune system - a physician's view. Dev Comp Immunol. 2009; 33:267-72.

101. Salmon H, Berri M, Gerdts V, Meurens F. Humoral and cellular factors of maternal immunity in swine. Dev Comp Immunol. 2009; 33:384-93.

102. Sánchez-Vizcaíno, JM. Células del Sistema Inmune. Inmunoglobulinas porcinas. En: Sanchez-Vizcaíno, JM Curso de introducción a la inmunología porcina. 3ra Edición. 2010. http://sanidadanimal.info/cursos/inmunologia3/

103. Sanchis EG, Merkis CI, Koncurat MA. Detección de glicoconjugados en las vellosidades placentarias porcinas de diferentes períodos gestacionales. Red Vet. 2009; 10(12):1-15.

104. Senger PL. Placentation, the Endocrinology of gestation and Parturition. 2da Edición Washington: Current Conceptions Inc, 2003, p. 304-25.

105. Šinkora J, Butler JE. The ontogeny of the porcine immune system. Dev Comp Immunol. $2009 ; 33: 273-83$.

106. Šinkora M, Butler JE, Holtmeier W, Šinkorova J. Lymphocyte development in fetal piglets: facts and surprises. Vet Immunol Immunopathol. 2005; 108:177-84.

107. Šinkora M, Sun J, Šinkorova J, Christenson RK, Ford SP, Butler JE. Antibody repertoire development in fetal and neonatal piglets. VI. B cell lymphogenesis occurs at multiple sites with differences in the frequency of in-frame rearrangements. J Immunol. 2003; 170:1781-88.

108. Song G, Bailey D, Dunlap K, Burghardt R, Spencer T, Bazer F, Johnson G. Cathepsin B, cathepsin $\mathrm{L}$, and cystatin $\mathrm{C}$ in the porcine uterus and placenta: potential roles in endometrial/placental remodeling and in fluid-phase transport of proteins secreted by uterine epithelia across placental areolae. Biol Reprod. 2010; 82:854-64. 
109. Spencer TE, Bazer FW. Conceptus signals for establishment and maintenance of pregnancy. Reprod Biol Endocrinol. 2004a; 2:1-15.

110. Spencer TE, Bazer FW. Uterine and placental factors regulating conceptus growth in domestic animals. J Anim Sci. 2004b; 82 (E. Suppl):4-13.

111. Stirling C, Charleston B, Takamatsu H, Claypool S, Lencer W, Blumberg R, Wileman T. Characterization of the porcine neonatal Fc receptor- potential use for trans-epithelial protein delivery. J Immunol. 2005; 114:542-53.

112. Stroband H, Van der Lende T. Embryonic and uterine development during pregnancy. J Reprod Fertil. 1990; 40:261-77.

113. Szafranska B, Majewska M, Panasiewicz G. N-Glycodiversity of the pregnancyassociated glycoprotein family (PAG) produced in vitro by trophoblast and trophectoderm explants during implantation, placentation and advanced pregnancy in the pig. Biol Reprod. 2004; 4(1):67-89.

114. Tennant LM, Renard C, Chardon P, Powell PP. Regulation of porcine classical and nonclassical MHC class I expression. Immunogenetics. 2007; 181:2494-505.

115. Tizard IR. Órganos del Sistema Inmune. En: Tizard IR. Introducción a la Inmunología Veterinaria. 8 va. Edición. Barcelona, España, Ed. Elsevier, 2009, p. 113-27.

116. Trolliet J. Productividad numérica de la cerda. Factores y componentes que la afectan. 2005. [Online] http://www.produccion-animal.com.ar/produccion_porcina

117. United States Department of Agriculture. 2011. [Citado el 5 de Noviembre de 2014] [Online] http://www.usda.gov

118. Vallet JL, Freking BA. Differences in placental structure during gestation associated with large and small pig fetus. J Anim Sci. 2007; 85:3267-75. 
119. Van der Lende T, Van Rens B. Critical periods for fetal mortality in gilts identified by analyzing the length distribution of mummified fetuses and frequency of non-freshstillborn piglets. Anim Reprod Sci. 2003; 75:141-50.

120. Wagstrom EA, Yoon K-J, Zimmerman JJ. Immune components in porcine mammary secretions. Viral Immunol. 2000; 13:383-97.

121. Watson DL. Immunological functions of the mammary gland and its secretion; comparative review. Aust J Biol Sci. 1980; 33:4013-22.

122. Wilson ME, Ford SP. Comparative aspects of placental efficiency. Reproduction 2001; 58:223-32.

123. Wilson ME, Sonstegard TS, Smith TP, Fahrenkrug SC, Ford SP. Differential gene expression during elongation in the preimplantation pig embryo. Genesis. 2000; 26:9-14.

124. Williamson D. Estudio de la presencia de integrinas y su relación con los niveles de esteroides e interleuquinas, durante la placentación porcina. Tesis doctoral. Facultad de Ciencias Veterinarias. Universidad Nacional de La Plata. 2010.

125. Williamson DM, Riesco OF, Vélez C, Koncurat MA. Determinación de la concentración de IFN-r, IL-6, IL-12, IL-15 e IL-18 en suero, extractos placentarios maternos y fetales a través de la gestación porcina. Ciencia Veterinaria. 2011; 13:31-41.

126. Wooding P, Burton G. Eutheria: Epitheliochorial placentation pig and horse. En: Comparative Placentation. Structures, Functions and Evolution. 1ra Edición. Berlín, Alemania, Ed. Springer, 2008. p. 105-14.

127. Xia P, Liu X, Zhang Z, Duan E, Lu X, Zhao J, Cui B. Molecular cloning and characterization of a porcine Fc gamma RIIb sub-isoform (FcyRIIb1). Vet Immunol Immunopathol. $2011 ; 141: 144-50$. 
128. Ye L, Tuo W, Liu X, Simister NE, Zhu X . Identification and characterization of an alternatively spliced variant of the MHC class I-related porcine neonatal Fc receptor for IgG. Dev Comp Immunol. 2008; 32(8):966-79.

129. Zenclussen AC, Gentile MT, Kortebani A, Mazzolli R, Margni RA. Asymmetric antibodies and pregnancy. J Reprod Immunol. 2001; 45:289-94.

130. Zubeldía D. Estudio ultraestructural y de residuos glicosilados en la placenta porcina. Tesis de maestría. Facultad de Agronomía y Veterinaria. Universidad Nacional de Río Cuarto, 2007. 


\section{ANEXO 1}

\section{Determinación de anticuerpos IgG asimétricos}

Tabla 3a. Porcentaje de anticuerpos IgG asimétricos en sueros en cerdas vacías (0) y preñadas en diferentes períodos gestacionales. Se consignan los valores de n, media (mg/dl), desvío estándar (D.E.), error estándar (E.E.), valores mínimos y máximos y percentiles 5 y 95.

\begin{tabular}{|r|r|r|r|r|r|r|r|r|}
\hline $\begin{array}{r}\text { Período } \\
\text { Gestacional }\end{array}$ & $\mathrm{n}$ & Media & D.E. & E.E. & Mín. & Máx. & $\mathrm{P}(0,5)$ & $\mathrm{P}(95)$ \\
\hline 0 & 25 & 38,34 & 13,32 & 2,66 & 17,18 & 59,70 & 19,50 & 57,80 \\
\hline 30 días & 19 & 32,15 & 12,14 & 2,78 & 16,90 & 53,00 & 16,90 & 53,00 \\
\hline $65-70$ días & 21 & 36,02 & 11,17 & 2,44 & 18,60 & 51,44 & 18,65 & 51,40 \\
\hline $95-114$ días & 21 & 43,31 & 13,40 & 2,92 & 13,00 & 65,80 & 22,80 & 60,00 \\
\hline
\end{tabular}

Tabla 3b. Porcentaje de anticuerpos IgG asimétricos en homogenatos de placenta materna en diferentes períodos gestacionales. Se consignan los valores de n, media (mg/dl), desvío estándar (D.E.), error estándar (E.E.), valores mínimos y máximos y percentiles 5 y 95.

\begin{tabular}{|r|r|r|r|r|r|r|r|r|}
\hline $\begin{array}{r}\text { Período } \\
\text { Gestacional }\end{array}$ & $\mathrm{N}$ & Media & D.E. & E.E. & Mín & Máx & $\mathrm{P}(05)$ & $\mathrm{P}(95)$ \\
\hline vacía & 4 & 20,50 & & 5,94 & & & & \\
\hline 30 días & 24 & 26,82 & 7,63 & 1,56 & 16,19 & 46,72 & 16,34 & 42,00 \\
\hline $65-70$ días & 23 & 44,62 & 11,32 & 2,36 & 26,48 & 65,67 & 28,00 & 65,67 \\
\hline $95-114$ días & 4 & 13,50 & 3,87 & 1,94 & 9,00 & 18,00 & 9,00 & 18,00 \\
\hline
\end{tabular}


Tabla 3c. Porcentaje de anticuerpos IgG asimétricos en homogenatos de placenta fetal en diferentes períodos gestacionales. Se consignan los valores de n, media $(\mathrm{mg} / \mathrm{dl})$, desvío estándar (D.E.), error estándar (E.E.), valores mínimos y máximos y percentiles 5 y 95.

\begin{tabular}{|r|r|r|r|r|r|r|r|r|}
\hline $\begin{array}{r}\text { Período } \\
\text { Gestacional }\end{array}$ & $\mathrm{n}$ & Media & D.E. & E.E. & Mín & Máx & $\mathrm{P}(05)$ & $\mathrm{P}(95)$ \\
\hline 30 días & 4 & 52,28 & 7,27 & 3,64 & 44,00 & 61,63 & 44,00 & 61,63 \\
\hline 65-70 días & 11 & 43,66 & 9,72 & 2,93 & 32,00 & 55,40 & 32,00 & 55,40 \\
\hline $95-114$ días & 8 & 46,69 & 13,63 & 4,82 & 24,00 & 64,18 & 24,00 & 64,18 \\
\hline
\end{tabular}

Tabla 4. Porcentaje de anticuerpos IgG asimétricos en sueros de cerdas preñadas $(\mathrm{P})$ y vacías (V). Se consignan los valores de n, media (mg/dl), desvío estándar (D.E.), error estándar (E.E.), valores mínimos y máximos y mediana en sueros, teniendo en cuenta si las cerdas estaban vacías o preñadas.

\begin{tabular}{|r|r|r|r|r|r|r|r|r|}
\hline Vac vs. Pre & $\mathrm{n}$ & Media & D.E. & E.E. & Mín & Máx & $\mathrm{P}(05)$ & $\mathrm{P}(95)$ \\
\hline Vac & 25 & 38,34 & 13,32 & 2,66 & 17,18 & 59,70 & 19,50 & 57,80 \\
\hline Pre & 61 & 37,32 & 12,93 & 1,66 & 13,00 & 65,80 & 17,00 & 59,00 \\
\hline
\end{tabular}


Tabla 5: Concentración de anticuerpos IgG asimétricos en sueros de cerdas vacías y en sueros de cerdas en diferentes períodos gestacionales. Se consignan los valores de $\mathrm{n}$, media (mg/dl), error estándar (E.E.), y se marcan las diferencias significativas halladas (Figura 15). (Test: Tukey Al$\mathrm{fa}=0,05 \mathrm{DMS}=10,09672$. Error: 158, 5552 gl: 82 ).

\begin{tabular}{|r|r|r|r|rr|}
\hline Período Gestacional & $\mathrm{n}$ & Medias & E.E. & Test de Tukey \\
\hline Vacías & 25 & 38,34 & 2,52 & $\mathrm{~A}$ & $\mathrm{~B}$ \\
\hline 30 días & 19 & 32,15 & 2,89 & & $\mathrm{~B}$ \\
\hline $65-70$ días & 21 & 36,02 & 2,75 & $\mathrm{~A}$ & $\mathrm{~B}$ \\
\hline $95-114$ días & 21 & 43,31 & 2,75 & \multicolumn{2}{|c|}{$\mathrm{A}$} \\
\hline
\end{tabular}

${ }^{*}$ Letras distintas indican diferencias significativas $(p<=0,05)$.

Tabla 6: Concentración de anticuerpos IgG asimétricos en HoU y en HoPM de cerdas en diferentes períodos gestacionales. Se consignan los valores de n, media (mg/dl), error estándar (E.E.), y se marcan las diferencias significativas halladas (Figura 16). (Test de Tukey: Alfa $=0,05$ DMS=8,87009. Error: 87,5799 gl: 48).

\begin{tabular}{|c|c|c|c|c|}
\hline Período Gestacional & $\mathrm{n}$ & Medias & E.E. & Test de Tukey \\
\hline vacía & 4 & 20,50 & $\overline{5,94}$ & B \\
\hline 30 días & 24 & 26,82 & 1,91 & B \\
\hline 65-70 días & 23 & 44,62 & 1,95 & $\mathrm{D}$ \\
\hline 95-114 días & 4 & 13,50 & 4,68 & A \\
\hline
\end{tabular}

*Letras distintas indican diferencias significativas $(p<=0,05)$. 
Tabla 7: Concentración de anticuerpos IgG asimétricos en HoPF de cerdas en diferentes períodos gestacionales. Se consignan los valores de n, media (mg/dl), error estándar (E.E.), y se marcan las diferencias significativas halladas (Figura 17). (Test de Tukey: Alfa=0,05 DMS=14,76318. Error: 120, 2106 gl: 20).

\begin{tabular}{|r|r|r|r|l|}
\hline Período Gestacional & $\mathrm{n}$ & Medias & E.E. & Test de Tukey \\
\hline 30 días & 4 & 52,28 & 5,48 & $\mathrm{~A}$ \\
\hline $65-70$ días & 11 & 43,66 & 3,31 & $\mathrm{~A}$ \\
\hline $95-114$ días & 8 & 46,69 & 3,88 & $\mathrm{~A}$ \\
\hline
\end{tabular}

*Letras distintas indican diferencias significativas $(p<=0,05)$. 
Anexo

\section{ANEXO 2}

\section{Cuantificación de proteínas totales, albúmina y de IgG en suero}

Tabla 8. Concentración de PrT en sueros de cerdas vacías (0) y en los diferentes períodos gestacionales. Se consignan los valores de n, media (mg/dl), desvío estándar (D.E.), valores mínimos y máximos y percentiles 5 y 95.

\begin{tabular}{|r|r|r|r|r|r|r|r|r|}
\hline $\begin{array}{r}\text { Período } \\
\text { Gestacional }\end{array}$ & PrT & $\mathrm{n}$ & Media & D.E. & Mín & Máx & P(05) & P(95) \\
\hline Vacías & PrT & 8 & $8.458,75$ & $1.307,06$ & $6.900,00$ & $9.950,00$ & $6.900,00$ & $9.950,00$ \\
\hline 30 días & PrT & 26 & $7.517,31$ & 981,92 & $5.700,00$ & $8.850,00$ & $5.900,00$ & $8.800,00$ \\
\hline 65- 70 días & PrT & 10 & $7.968,00$ & $1.260,13$ & $5.700,00$ & $9.660,00$ & $5.700,00$ & $9.660,00$ \\
\hline $95-114$ días & PrT & 5 & $7.218,00$ & 278,60 & $7.000,00$ & $7.700,00$ & $7.000,00$ & $7.700,00$ \\
\hline
\end{tabular}

Tabla 9. Concentración de Alb en sueros de cerdas vacías (0) y en los diferentes períodos gestacionales. Se consignan los valores de n, media (mg/dl), desvío estándar (D.E.), valores mínimos y máximos y percentiles 5 y 95 .

\begin{tabular}{|l|l|l|l|l|l|l|l|l|}
\hline $\begin{array}{c}\text { Período } \\
\text { Gestacional }\end{array}$ & Alb & $\mathrm{N}$ & Media & D.E. & Mín & Máx & $\mathrm{P}(05)$ & $\mathrm{P}(95)$ \\
\hline Vacías & Alb & 8 & $3.972,50$ & 658,54 & $2.800,00$ & $4.560,00$ & $2.800,00$ & $4.560,00$ \\
\hline 30 días & Alb & 26 & $3.693,96$ & 850,68 & $2.300,00$ & $5.100,00$ & $2.500,00$ & $5.100,00$ \\
\hline 65-70 días & Alb & 10 & $3.638,00$ & $1.061,12$ & $2.300,00$ & $5.000,00$ & $2.300,00$ & $5.000,00$ \\
\hline 95-114 días & Alb & 5 & $3.906,00$ & 769,27 & $3.000,00$ & $4.760,00$ & $3.000,00$ & $4.760,00$ \\
\hline
\end{tabular}


Tabla 10. Concentración de IgG sérica determinada mediante inmunoturbidimetría (Turb) en cerdas vacías (0) y preñadas en diferentes períodos gestacionales. Se consignan los valores de n, media (mg/dl), desvío estándar (D.E.), valores mínimos y máximos y percentiles 5 y 95.

\begin{tabular}{|r|r|r|r|r|r|r|r|r|}
\hline $\begin{array}{r}\text { Período } \\
\text { Gestacional }\end{array}$ & $\begin{array}{r}\text { IgG } \\
\text { (Turb) }\end{array}$ & $\mathrm{n}$ & Media & D.E. & Mín & Máx & $\mathrm{P}(05)$ & $\mathrm{P}(95)$ \\
\hline Vacías & $\operatorname{IgG}$ & 7 & 731,00 & 183,33 & 443,00 & 952,00 & 443,00 & 952,00 \\
\hline 30 días & $\operatorname{IgG}$ & 21 & 576,50 & 133,66 & 414,00 & 834,00 & 449,00 & 834,00 \\
& $\operatorname{IgG}$ & 7 & 694,67 & 176,76 & 485,00 & 992,20 & 485,00 & 992,20 \\
\hline $65-70$ días & IgG & 4 & 578,58 & 77,02 & 525,10 & 692,00 & 525,10 & 692,00 \\
\hline $95-114$ días & & & & & & & & \\
\hline
\end{tabular}

Tabla 11. Concentración de IgG, mediante IDR, en sueros de cerdas vacías (0) y preñadas en distintos períodos gestacionales. Se consignan los valores de $\mathrm{n}$, media (mg/dl), desvío estándar (D.E.), valores mínimos y máximos y percentiles 5 y 95.

\begin{tabular}{|l|l|l|l|l|l|l|l|l|}
\hline $\begin{array}{c}\text { Período } \\
\text { Gestacional }\end{array}$ & IgG(IDR) & $\mathrm{n}$ & Media & D.E. & Mín & Máx & $\mathrm{P}(05)$ & $\mathrm{P}(95)$ \\
\hline Vacías & IgG & 6 & $2.345,0$ & 277,33 & $1.930,0$ & $2.800,0$ & $1.930,0$ & $2.800,0$ \\
\hline 30 días & IgG & 15 & $3.387,8$ & 479,86 & $2.036,0$ & $3.800,0$ & $2.036,0$ & $3.800,0$ \\
\hline 65-70 días & IgG & 5 & $3.075,4$ & 614,80 & $2.129,0$ & $3.600,0$ & $2.129,0$ & $3.600,0$ \\
\hline 95-114 días & IgG & 4 & $1.147,0$ & 127,28 & $1.057,0$ & $1.237,0$ & $1.057,0$ & $1.237,0$ \\
\hline
\end{tabular}


Tabla 12. Concentración de PrT en suero entre cerdas vacías y preñadas. Se consignan los valores de $\mathrm{n}$, media (mg/dl), error estándar (E.E.) y se marcan las diferencias significativas halladas (Figura 18). (Test de Tukey: Alfa=0,05 DMS=722,11392. Error: 1090133,9948 gl: 4).

\begin{tabular}{|r|r|r|r|r|}
\hline Vac vs Pre & $\mathrm{n}$ & Medias & E.E. & Test de Tukey \\
\hline Vac & 7 & $8.681,43$ & 394,63 & B \\
\hline Pre & 41 & $7.590,73$ & 163,06 & A \\
\hline
\end{tabular}

*Letras distintas indican diferencias significativas $(p<=0,05)$.

Tabla 13. Concentración de Alb en suero entre cerdas vacías y preñadas. Se consignan los valores de $\mathrm{n}$, media (mg/dl), error estándar (E.E.) y se marcan las diferencias significativas halladas. (Test de Tukey: Alfa=0,05 DMS=567,54933. Error: 720726,0768 gl: 47).

\begin{tabular}{|r|r|r|r|r|}
\hline Vac vs Pre & $\mathrm{n}$ & Medias & E.E. & Test de Tukey \\
\hline Vac & 8 & $3.972,50$ & 300,15 & $\mathrm{~A}$ \\
\hline Pre & 41 & $3.706,10$ & 132,58 & $\mathrm{~A}$ \\
\hline
\end{tabular}

*Letras distintas indican diferencias significativas $(p<=0,05)$.

Tabla 14. Concentración de IgG (Turb) en suero entre cerdas vacías y preñadas. Se consignan los valores de $\mathrm{n}$, media $(\mathrm{mg} / \mathrm{dl})$, error estándar (E.E.) y se marcan las diferencias significativas halladas (Figura 19). (Test de Tukey: Alfa=0,05 DMS=111,61429. Error: 22707,6532 gl: 37).

\begin{tabular}{|r|r|r|r|r|}
\hline Vac vs Pre & $\mathrm{n}$ & Medias & E.E. & Test de Tukey \\
\hline Vac & 7 & 731,00 & 56,96 & B \\
\hline Pre & 32 & 602,61 & 26,64 & A \\
\hline
\end{tabular}

${ }^{*}$ Letras distintas indican diferencias significativas $(p<=0,05)$. 
Tabla 15. Concentración de IgG (IDR) en suero entre cerdas vacías y preñadas. Se consignan los valores de n, media (mg/dl), error estándar (E.E.) y se marcan las diferencias significativas halladas (Figura 20). (Test de Tukey: Alfa=0,05 DMS=629,46850. Error: 538713,1469 gl: 26).

\begin{tabular}{|r|r|r|r|c|}
\hline Vac vs Pre & $\mathrm{n}$ & Medias & E.E. & \multicolumn{2}{|c|}{ Test de Tukey } \\
\hline Vac & 6 & $2.345,00$ & 299,64 & $\mathrm{~A}$ \\
\hline Pre & 22 & $3.113,09$ & 156,48 & B \\
\hline
\end{tabular}

*Letras distintas indican diferencias significativas $(p<=0,05)$.

Tabla 16. Concentración sérica de PrT entre cerdas vacías y preñadas en los períodos gestacionales estudiados. Se consignan los valores de n, media (mg/dl), error estándar (E.E.) y se marcan las diferencias significativas halladas (Figura 21). (Test de Tukey: Alfa=0,05 DMS=1260,47486. Error: $1088364,4830 \mathrm{gl}: 44)$.

\begin{tabular}{|c|c|c|c|c|}
\hline Período Gestacional & $\mathrm{n}$ & Medias & E.E. & Test de Tukey \\
\hline Vacías & 7 & $8.681,43$ & 394,31 & $\mathrm{~B}$ \\
\hline 30 días & 26 & $7.517,31$ & 204,60 & $\mathrm{~A}$ \\
\hline 65-70 días & 10 & $7.968,00$ & 329,90 & $\mathrm{~A}$ \\
\hline 95-114 días & 5 & $7.218,00$ & 466,55 & $\mathrm{~A}$ \\
\hline
\end{tabular}

*Letras distintas indican diferencias significativas $(p<=0,05)$.

Tabla 17. Concentración sérica de Alb entre cerdas vacías y preñadas en los períodos gestacionales estudiados Se consignan los valores de n, media (mg/dl), error estándar (E.E.) y se marcan las diferencias significativas halladas. (Test de Tukey: Alfa=0,05 DMS=1026,22233. Error: 747201,0085 gl: 45).

\begin{tabular}{|r|r|r|r|r|}
\hline Período Gestacional & $\mathrm{n}$ & Medias & E.E & Test de Tukey \\
\hline Vacías & 8 & $3.972,50$ & 305,61 & $\mathrm{~A}$ \\
\hline $30 \mathrm{~d}$ & 26 & $3.693,80$ & 169,52 & $\mathrm{~A}$ \\
\hline $65-70 \mathrm{~d}$ & 10 & $3.638,00$ & 273,35 & $\mathrm{~A}$ \\
\hline $95-114 \mathrm{~d}$ & 5 & $.3906,00$ & 386,57 & $\mathrm{~A}$ \\
\hline
\end{tabular}

*Letras distintas indican diferencias significativas $(p<=0,05)$. 
Tabla 18. Concentración sérica de $\operatorname{IgG}$ (Turb) entre cerdas vacías y preñadas en los períodos gestacionales estudiados. Se consignan los valores de n, media (mg/dl), error estándar (E.E.) y se marcan las diferencias significativas halladas.(Test de Tukey: Alfa=0,05 DMS=199,13545. Error: 21835,1121 gl: 35).

\begin{tabular}{|r|r|r|r|r|}
\hline Período Gestacional & $\mathrm{n}$ & Muestra & E.E. & Test de Tukey \\
\hline Vacías & 7 & 731,00 & 55,85 & $\mathrm{~A}$ \\
\hline $30 \mathrm{~d}$ & 21 & 576,50 & 32,25 & $\mathrm{~A}$ \\
\hline $65-70 \mathrm{~d}$ & 7 & 694,67 & 55,85 & $\mathrm{~A}$ \\
\hline $95-114 \mathrm{~d}$ & 4 & 578,58 & 73,88 & $\mathrm{~A}$ \\
\hline
\end{tabular}

*Letras distintas indican diferencias significativas $(p<=0,05)$.

Tabla 19. Concentración sérica de IgG (IDR) entre cerdas vacías y preñadas en los períodos gestacionales estudiados. Se consignan los valores de n, media (mg/dl), error estándar (E.E.) y se marcan las diferencias significativas halladas (Figura 22). (Test de Tukey: Alfa $=0,05$ DMS=771,16996. Error: 214018,1500 gl: 24).

\begin{tabular}{|r|r|r|r|cc|}
\hline Período Gestacional & $\mathrm{n}$ & Medias & E.E. & Test de Tukey \\
\hline Vacías & 6 & $2.345,00$ & 188,86 & $\mathrm{~B}$ \\
\hline 30 días & 15 & $3.387,80$ & 119,45 & & $\mathrm{C}$ \\
\hline 65-70 días & 5 & $3.075,40$ & 206,89 & $\mathrm{~B}$ & $\mathrm{C}$ \\
\hline 95-114 días & 2 & $1.147,00$ & 327,12 & A & \\
\hline
\end{tabular}

*Letras distintas indican diferencias significativas $(p<=0,05)$. 


\section{Cuantificación de proteínas totales y de IgG en homogenatos placentarios maternos} (HoPM)

Tabla 20. Concentración de PrT en extractos uterinos en cerdas vacías y en extractos placentarios maternos en cerdas de diferentes períodos gestacionales. Se consignan los valores de n, media (mg/dl), desvío estándar (D.E.), valores mínimos y máximos y percentiles 5 y 95.

\begin{tabular}{|r|r|r|l|r|r|r|r|r|}
\hline $\begin{array}{r}\text { Período } \\
\text { Gestacional }\end{array}$ & N & Muestra & Media & D.E. & Mín & Máx & P(05) & P(95) \\
\hline Vacías & 4 & PrT & 284,75 & 104,74 & 155,00 & 404,00 & 155,00 & 404,00 \\
\hline 30 días & 14 & PrT & 279,94 & 147,42 & 110,80 & 528,00 & 110,80 & 528,00 \\
& & & & & & & & \\
\hline $65-70$ días & 5 & PrT & 598,04 & 149,91 & 352,60 & 719,60 & 352,60 & 719,60 \\
\hline $95-114$ días & 9 & PrT & 271,97 & 159,30 & 90,00 & 540,00 & 90,00 & 540,00 \\
\hline
\end{tabular}

Tabla 21. Concentración de IgG (Turb) en extractos uterinos en cerdas vacías y en extractos placentarios maternos en cerdas de diferentes períodos gestacionales. Se consignan los valores de n, media (mg/dl), desvío estándar (D.E.), valores mínimos y máximos y percentiles 5 y 95.

\begin{tabular}{|r|r|l|r|r|r|r|r|r|}
\hline $\begin{array}{l}\text { Período } \\
\text { Gestacional }\end{array}$ & N & Muestra & Media & D.E. & Mín & Máx & P(05) & P(95) \\
\hline Vacías & 4 & IgG (Turb) & 87,50 & 17,00 & 62,00 & 96,00 & 62,00 & 96,00 \\
\hline 30 días & 18 & IgG (Turb) & 39,61 & 18,51 & 16,00 & 87,70 & 16,00 & 87,70 \\
\hline 65-70 días & 5 & IgG (Turb) & 37,72 & 17,26 & 30,00 & 68,60 & 30,00 & 68,60 \\
\hline 95-114 días & 10 & IgG (Turb) & 30,00 & 0,00 & 30,00 & 30,00 & 30,00 & 30,00 \\
\hline
\end{tabular}


Tabla 22. Concentración de PrT en extractos placentarios maternos en cerdas vacías y preñadas. Se consignan los valores de n, media (mg/dl), error estándar (E.E.) y se marcan las diferencias significativas halladas. (Test de Tukey: Alfa=0,05 DMS=164,70305. Error: 34415,5692 gl: 30).

\begin{tabular}{|r|r|r|r|r|}
\hline Vac vs Pre & $\mathrm{n}$ & Media & E.E. & Test de Tukey \\
\hline Vac & 4 & 284,75 & 92,76 & $\mathrm{~A}$ \\
\hline Pre & 28 & 334,18 & 35,06 & $\mathrm{~A}$ \\
\hline
\end{tabular}

*Letras distintas indican diferencias significativas $(p<=0,05)$.

Tabla 23. Concentración de PrT en HoU de cerdas vacías y en HoPM de los diferentes períodos gestacionales. Se consignan los valores de $\mathrm{n}$, media $(\mathrm{mg} / \mathrm{dl})$, error estándar (E.E.) y se marcan las diferencias significativas halladas (Figura 24). (Test de Tukey: Alfa=0,05 DMS=213,81688. Error: $21725,9962 \mathrm{gl}: 28)$.

\begin{tabular}{|r|r|r|r|c|}
\hline Período Gestacional & $\mathrm{n}$ & Medias & E.E. & Test de Tukey \\
\hline Vacías & 4 & 284,75 & 73,70 & $\mathrm{~A}$ \\
\hline $30 \mathrm{~d}$ & 14 & 279,94 & 39,39 & $\mathrm{~A}$ \\
\hline $65-70 \mathrm{~d}$ & 5 & 598,04 & 65,92 & $\mathrm{~B}$ \\
\hline $95-114 \mathrm{~d}$ & 9 & 271,97 & 49,13 & $\mathrm{~A}$ \\
\hline
\end{tabular}

*Letras distintas indican diferencias significativas $(p<=0,05)$.

Tabla 24. Concentración de IgG (Turb) en homogenatos de útero de cerdas vacías y en homogenatos de extractos placentarios maternos. Se consignan los valores de $\mathrm{n}$, media (mg/dl), error estándar (E.E.) y se marcan las diferencias significativas halladas (Figura 25). (Test de Tukey: Al$\mathrm{fa}=0,05 \mathrm{DMS}=13,18847$. Error: 242,4419 gl: 35 ).

\begin{tabular}{|r|r|r|r|r|}
\hline Vac vs Pre & $\mathrm{n}$ & Medias & E.E. & Test de Tukey \\
\hline Vac & 4 & 87,50 & 7,79 & $\mathrm{~B}$ \\
\hline Pre & 33 & 36,41 & 2,71 & $\mathrm{~A}$ \\
\hline
\end{tabular}

*Letras distintas indican diferencias significativas $(p<=0,05)$. 
Tabla 25. Concentración de IgG (Turb) en extractos placentarios maternos en cerdas vacías y en los diferentes períodos gestacionales. Se consignan los valores de n, media (mg/dl), error estándar (E.E.) y se marcan las diferencias significativas halladas (Figura 26). (Test de Tukey: Alfa=0,05 DMS=21,24236. Error: 238,8545 gl: 33).

\begin{tabular}{|r|r|r|r|r|}
\hline Período Gestacional & $\mathrm{n}$ & Medias & E.E. & Test de Tukey \\
\hline Vacías & 4 & 87,50 & 7,73 & $\mathrm{~B}$ \\
\hline 30 días & 18 & 39,61 & 3,64 & $\mathrm{~A}$ \\
\hline $65-70$ días & 5 & 37,72 & 6,91 & $\mathrm{~A}$ \\
\hline $95-114$ días & 10 & 30,00 & 4,89 & $\mathrm{~A}$ \\
\hline
\end{tabular}

${ }^{*}$ Letras distintas indican diferencias significativas $(p<=0,05)$.

Tabla 26. Concentración de $\operatorname{IgG}$ (IDR) en extractos placentarios maternos en cerdas vacías vs 95-114d de gestación. Se consignan los valores de n, media (mg/dl), desvío estándar (D.E.), valores mínimos y máximos y percentiles 5 y 95 .

\begin{tabular}{|r|r|r|r|r|r|r|r|r|}
\hline $\begin{array}{r}\text { Período } \\
\text { Gestacional }\end{array}$ & $\mathrm{n}$ & Muestra & Media & D.E. & Mín & Máx & $\mathrm{P}(05)$ & $\mathrm{P}(95)$ \\
\hline Vacía & 4 & $\begin{array}{r}\text { IgG } \\
(\mathrm{IDR})\end{array}$ & 143,25 & 23,68 & 120,00 & 176,00 & 120,00 & 176,00 \\
\hline $95-114$ días & 7 & $\begin{array}{r}\text { IgG } \\
(\mathrm{IDR})\end{array}$ & 347,00 & 179,83 & 100,00 & 625,00 & 100,00 & 625,00 \\
\hline
\end{tabular}


Tabla 27. Concentración de IgG (IDR) en homogenato de útero no gestante y en extractos placentarios maternos de 95-114d de gestación. Se consignan los valores de n, media (mg/dl), error estándar (E.E).

\begin{tabular}{|r|r|r|r|r|}
\hline Periodo Gestacional & $\mathrm{n}$ & Medias & E.E. & Test de Tukey \\
\hline Vacía & 4 & 143,25 & 73,73 & $\mathrm{~A}$ \\
\hline $95-114$ días & 7 & 347,00 & 55,74 & $\mathrm{~A}$ \\
\hline
\end{tabular}

*Letras distintas indican diferencias significativas $(p<=0,05)$.

\section{Cuantificación de proteínas totales y de IgG en homogenatos placentarios fetales (HoPF)}

Tabla 28. Concentración de PrT en extractos placentarios fetales. Se consignan los valores de n, media (mg/dl), desvío estándar (D.E.), valores mínimos y máximos y percentiles 5 y 95.

\begin{tabular}{|r|r|r|r|r|r|r|r|r|}
\hline $\begin{array}{r}\text { Período } \\
\text { Gestacional }\end{array}$ & $\mathrm{n}$ & Muestra & Media & D.E. & Mín & Máx & $\mathrm{P}(05)$ & $\mathrm{P}(95)$ \\
\hline 30 días & 9 & PrT & 347,24 & 237,06 & 74,00 & 820,00 & 74,00 & 820,00 \\
\hline 65-70 días & 7 & PrT & 206,29 & 231,93 & 91,60 & 730,00 & 91,60 & 730,00 \\
\hline 95-114 días & 4 & PrT & 235,65 & 118,73 & 130,00 & 390,00 & 130,00 & 390,00 \\
\hline
\end{tabular}

Tabla 29. Concentración de IgG (Turb) en extractos placentarios fetales. Se consignan los valores de n, media (mg/dl), desvío estándar (D.E.), valores mínimos y máximos y percentiles 5 y 95.

\begin{tabular}{|r|r|r|r|r|r|r|r|r|}
\hline Período Gestacional & $\mathrm{n}$ & Muestra & Media & D.E. & Mín & Máx & $\mathrm{P}(05)$ & $\mathrm{P}(95)$ \\
\hline 30 días & 10 & IgG (Turb) & 40,78 & 25,52 & 30,00 & 111,80 & 30,00 & 111,80 \\
\hline $65-70$ días & 10 & IgG (Turb) & 38,05 & 28,42 & 21,90 & 118,60 & 21,90 & 118,60 \\
\hline $95-114$ días & 4 & IgG (Turb) & 30,00 & 0,00 & 30,00 & 30,00 & 30,00 & 30,00 \\
\hline
\end{tabular}


Tabla 30. Concentración de PrT (mg/dl) extractos placentarios fetales en los períodos gestacionales estudiados. Se consignan los valores de n, media (mg/dl), error estándar (E.E.) y se marcan las diferencias significativas halladas. (Test de Tukey: Alfa=0,05 DMS=292,87060. Error: 49736,7353 gl: 21).

\begin{tabular}{|r|r|r|r|r|}
\hline Período Gestacional & $\mathrm{n}$ & Medias & E.E. & Test de Tukey \\
\hline 30 días & 10 & 322,02 & 70,52 & $\mathrm{~A}$ \\
\hline 65-70 días & 10 & 259,72 & 70,52 & $\mathrm{~A}$ \\
\hline 95-114 días & 4 & 235,65 & 111,51 & $\mathrm{~A}$ \\
\hline
\end{tabular}

*Letras distintas indican diferencias significativas $(p<=0,05)$.

Tabla 31. Concentración de $\operatorname{IgG}$ (Turb) en extractos placentarios fetales en los períodos gestacionales estudiados. Se consignan los valores de n, media (mg/dl), error estándar (E.E.) y se marcan las diferencias significativas halladas. (Test de Tukey: Alfa=0,05 DMS=32,83260. Error: 625,0810 gl: 21).

\begin{tabular}{|r|r|r|r|r|}
\hline Período Gestacional & $\mathrm{n}$ & Medias & E.E. & Test de Tukey \\
\hline 30 días & 10 & 40,78 & 7,91 & $\mathrm{~A}$ \\
\hline 65-70 días & 10 & 38,05 & 7,91 & $\mathrm{~A}$ \\
\hline 95-114 días & 4 & 30,00 & 12,50 & $\mathrm{~A}$ \\
\hline
\end{tabular}

*Letras distintas indican diferencias significativas $(p<=0,05)$.

Tabla 32. Concentración de IgG (IDR) en extractos placentarios fetales de 95-114d de gestación. Se consignan los valores de n, media (mg/dl), desvío estándar (D.E.), valores mínimos y máximos y percentiles 5 y 95 .

\begin{tabular}{|r|r|r|r|r|r|r|r|r|}
\hline Período Gestacional & $\mathrm{N}$ & Muestra & Media & D.E. & Mín & Máx & $\mathrm{P}(05)$ & $\mathrm{P}(95)$ \\
\hline $95-114$ días & 4 & IgG(IDR) & 175,00 & 51,13 & 124,00 & 219,00 & 124,00 & 219,00 \\
\hline
\end{tabular}

